Universidade de São Paulo

Faculdade de Filosofia, Ciências e Letras de Ribeirão Preto

Departamento de Química

Programa de Pós-Graduação em Química

\title{
A Atividade Orientadora de Ensino como alternativa metodológica para a abordagem de metais pesados na disciplina de Química Analítica Qualitativa
}

João Ricardo Sanchez

Dissertação apresentada à Faculdade de Filosofia, Ciências e Letras de Ribeirão Preto da Universidade de São Paulo, como parte das exigências para a obtenção do título de Mestre em Ciências. Área: Química

Ribeirão Preto - SP 
Universidade de São Paulo

Faculdade de Filosofia, Ciências e Letras de Ribeirão Preto

Departamento de Química

Programa de Pós-Graduação em Química

\section{A Atividade Orientadora de Ensino como alternativa metodológica para a abordagem de metais pesados na disciplina de Química Analítica Qualitativa}

João Ricardo Sanchez

Orientadora: Profa. Dra. Daniela Gonçalves de Abreu

Dissertação apresentada à Faculdade de Filosofia, Ciências e Letras de Ribeirão Preto da Universidade de São Paulo, como parte das exigências para a obtenção do título de Mestre em Ciências. Área: Química

Versão corrigida da Dissertação de Mestrado apresentada ao Programa de PósGraduação em Química no dia 01/08/2014. A versão original encontra-se disponível na Faculdade de Filosofia, Ciências e Letras de Ribeirão Preto.

Ribeirão Preto - SP 
Autorizo a reprodução e divulgação total ou parcial deste trabalho, por qualquer meio convencional ou eletrônico, para fins de estudo e pesquisa, desde que citada a fonte.

\section{FICHA CATALOGRÁFICA}

Sanchez, João Ricardo.

A Atividade Orientadora de Ensino como alternativa metodológica para a abordagem de metais pesados na disciplina de Química Analítica Qualitativa, 2014.

p. 104: Il. ; $30 \mathrm{~cm}$

Dissertação de Mestrado, apresentada à Faculdade de Filosofia, Ciências e Letras de Ribeirão Preto/USP. Área de concentração: Química.

Orientadora: Daniela Gonçalves de Abreu.

1. Química Analítica Qualitativa. 2. Metodologia. 3. Metais Pesados (grupos IV e V). 4. Atividade Orientadora de Ensino. 


\section{FOLHA DE APROVAÇÃO}

Nome: Sanchez, João Ricardo

Título: A Atividade Orientadora de Ensino como alternativa metodológica para a abordagem de metais pesados na disciplina de Química Analítica Qualitativa

Dissertação apresentada à Faculdade de Filosofia, Ciências e Letras de Ribeirão Preto da Universidade de São Paulo, como parte das exigências para a obtenção do título de Mestre em Ciências. Área: Química.

Aprovado em:

Prof. Dr.

Instituição:

Assinatura:

Prof. Dr.

Instituição:

Assinatura:

Prof. Dr.

Instituição:

Assinatura: 


\section{DEDICATÓRIA}

Oedica este trabatho aos meus pais ORosendo e Quzia, que sempre foram meus potenciais incentivadores e jamais mediram esforsos para que cada etapa dos meus estudos fosse concluida.

Obrigado por undo! Ama muito vocếs. 


\section{AGRADECIMENTOS}

A Deus e ao Espírito Santo, que sempre me concederam livramento, saúde e discernimento. Obrigado meu Pai, pelas bênçãos infinitas!

A professora Daniela, que além de orientadora, é uma pessoa muito amiga, amada e que sempre fez parte da minha vida acadêmica e particular. Obrigado por ser tão especial! Obrigado por toda a orientação, paciência, dedicação e comprometimento. Obrigado pelos momentos de "rabo de foguete", que me fizeram amadurecer muito.

A professora Yassuko Iamamoto, também orientadora e muito querida, que me abrigou em seu laboratório e disponibilizou a disciplina de Química Analítica Qualitativa (QAQ) para que nossa pesquisa fosse desenvolvida. Obrigado por toda a orientação e pelos ensinamentos de uma pessoa sensível e experiente.

A banca do exame de qualificação, professoras Elaine Araújo e Joana de Andrade pela leitura minuciosa e contribuições importantes para o nosso trabalho.

Aos alunos das IX, X e XI turma de Licenciatura em Química do DQ/FFCLRP.

Ao Fabrício Bortolucci Zanardi, grande amigo, companheiro de laboratório e que contribuiu com as filmagens dos encontros.

Ao Isaltino Alves Barbosa, monitor de QAQ, companheiro de laboratório, de disciplinas da pós, grande amigo que tive a oportunidade de cultivar. Obrigado por todo auxílio, conselhos e maturidade exemplar.

A Renata Bernardo Araújo, também monitora de QAQ, companheira de disciplinas da póse que compartilhou conosco a pesquisa em Ensino de Química.Obrigado pela amizade que construímose que ela possa perdurar! Que venham os próximos desafios (doutoramento).

Aos colegas de laboratório Douglas e Lucas Zanatta, pelo companheirismo e pela amizade.

Aos meus pais, Rosendo Maya Sanchez e Luzia Moreira Sanchez. Obrigado pelo imenso amor, carinho, dedicação e compreensão. Vocês sempre serão minha inspiração. São grandes exemplos de honestidade, hombridade, caráter e de como um pai deve criar um filho. Amo muito vocês. 
As minhas irmãs Kelly Cristina Sanchez e Kátia Cristina Sanchez, por todo o companheirismo e amizade. Obrigado por toda compreensão das minhas faltas, por aguentar a barra nos momentos em que tive que estudar, por serem tão presentes em minha vida. Amo muito vocês.

A minha vozinha querida Maria Ângela Sanchez Hernandes, que tanto amo e que é um exemplo de mulher guerreira e sensível. Obrigado por ser tão presente na minha vida desde sempre.

A toda a minha família (tios, tias, primos, cunhado), pelo amor e apoio incondicional ao meu trabalho e aos meus estudos.

A Daniela Mica Espimpolo, irmã de coração que é muito especial em minha vida. Obrigado pelo auxilio e orientação nos assuntos mais diversos, por todo o incentivo e apoio a minha pós-graduação, pelos momentos ótimos que já passamos juntos, por partilhar comigo o amor pelas atividades de docência. Foi sempre muito bom trabalhar com você e tenho certeza que Deus está trabalhando para que isto volte a acontecer.

A Thais Peres Gonçalves, por participar da minha vida a mais de 10 anos e ser meu referencial de maturidade e racionalidade. Obrigado pela linda amizade e pelos ótimos momentos de crescimento que já passamos juntos e pelos que ainda estão por vir!

Ao Renato Ferreira Matos, por toda a parceria destes últimos anos, pelo aprendizado e crescimento. Obrigado e que Deus abençoe. 
"Se te mandam quebrar uma pedra ou fazer um móvel, a inteligência vai te angustiar na procura do meio mais certo, mais eficiente e mais perfeito de quebrar ou de fazer, Mas a insaciedade que te faz artista vai te atirar numa procura muito mais afetiva, digna e criadora: saber o que é uma cadeira, que proveito os outros tirarão da pedra que você vai quebrar. Sem saber isso você será escravo."

Fernando Sabino

Assim são os educadores... 


\section{RESUMO}

A disciplina Química Analítica Qualitativa (QAQ), no contexto do Departamento de Química (DQ) da Faculdade de Filosofia, Ciências e Letras de Ribeirão Preto (FFCLRP), passou ao longo dos anos por uma redução de sua carga horária, que era de 11 horas semanais (1990) para 6 horas semanais (2001). Com a limitação na carga horária de QAQ, alguns grupos analíticos (grupos IV e V - Metais Pesados), foram aos poucos, deixando de ser abordados no curso de Licenciatura e Bacharelado em Química, ofertados pelo DQ. Devido à importância destes metais na atualidade, acreditamos que não poderiam ser suprimidos do currículo do nosso curso. Desta forma, elaborou-se uma AOE sobre os grupos analíticos IV e $\mathrm{V}_{\text {, que haviam sido }}$ retirados da marcha analítica e nesta dissertação o objetivo foi investigar a potencialidade da Atividade Orientadora de Ensino (AOE) como estratégia de ensinoaprendizagem em QAQ. A fundamentação teórica deste trabalho pautou-se nos estudos de Vygotsky sobre atividade e consciência e também na Teoria da Atividade proposta por Leontiev. Participaram da AOE 23 alunos da Licenciatura em Química, regularmente matriculados na disciplina de QAQ, que é oferecida no terceiro semestre do curso. A AOE foi desenvolvida no $1^{\circ}$ Semestre de 2013 e incluiu três encontros previamente acordados e inseridos no cronograma da disciplina. Os dois primeiros encontros foram desenvolvidos em duas aulas simples de 1h40, para a discussão teórica acerca do tema central - metais pesados - e consequente método de identificação e separação dos mesmos. Nestes, os alunos desenvolveram uma proposta de rota de separação, pautados em uma notícia acerca da utilização de metais em batons e brilhos labiais. O terceiro encontro foi desenvolvido no laboratório didático experimental, em uma aula dupla de $3 \mathrm{~h} 30$, na qual os alunos colocaram em prática a rota proposta, ao manipularem uma amostra fictícia dos cosméticos. Os encontros foram vídeos gravados, transcritos e posteriormente analisados a partir do método dialético. A metodologia de pesquisa adotada foi a pesquisa participante. A AOE como metodologia de ensino propiciou a interação entre os alunos da disciplina e o professor/pesquisador. Mobilizou os alunos a buscarem informações que pudessem solucionar os problemas relativos aos metais pesados, bem como articular as mesmas estabelecendo nexos entre elas e assim, conceber os conceitos envolvidos. No momento de discussão, pôde-se notar o favorecimento de nexos relacionados à: toxicidade dos metais e seus efeitos no corpo humano; bioacumulação e biomagnificação, saúde do homem, efeito das ações do homem no meio ambiente, impacto do conhecimento científico na sociedade e ambiente, proposta de identificação e separação, entre outros. Os momentos de fala externa para o grupo favoreceram que os alunos organizassem seu pensamento e sua compreensão dos conceitos. Esta AOE foi inserida na matriz curricular na disciplina e contribuiu para a avaliação dos alunos, que receberam uma nota na forma de "Prática como Componente Curricular", item exigido no projeto político pedagógico do curso de Licenciatura em Química.

Palavras-chave: Atividade Orientadora de Ensino; Metodologia; Química Analítica Qualitativa. 


\begin{abstract}
The Qualitative Analytical Chemistry discipline (QAC), in the context of the Chemistry Department (CD) of the Faculdade de Filosofia, Ciências e Letras de Ribeirão Preto-FFCLRP ("School of Philosophy, Sciences and Letters of Ribeirão Preto"), passed over the years by a reduction of its workload, which used to be 11 hours per week (1990) to 6 hours per week (2001). By limiting the workload of QAC, some analytical groups (groups IV and V - Heavy Metals), were gradually ceasing to be covered in the Chemistry Graduation Course, offered by CD. Due to the importance of these metals at present, we believe that they could not be removed from the curriculum of our course. Thus, a Teaching Guiding Activity (TGA) about the analytical groups IV and $\mathrm{V}$, which had been removed from the analytical procedures, has been elaborated and the objective in this dissertation was to investigate the potential of TGA as a teaching-learning strategy in QAC. The theoretical referential of this work was based on the studies of Vygotsky about activity and consciousness and also on the Activity Theory proposed by Leontiev. It was attended by 23 students of the Chemistry Graduation Course, regularly enrolled in the discipline of QAC, which is offered in the third semester of the course. The TGA was developed in the first semester of 2013, and included three meetings previously agreed into the schedule of the discipline. The two initial meetings were developed in two simple classes of $1 \mathrm{~h} 40$ to the theoretical discussion concerning the central subject - heavy metals - and consequent separation and identification method of the aforementioned metals. In these meetings, the students developed a proposal for separation, guided by a piece of news about the use of metals in lipsticks and lip gloss. The third meeting was developed in the experimental teaching laboratory, in a double lesson of $3 \mathrm{~h} 30$, in which the students put into practice the proposed route, by manipulating a fictitious sample of cosmetics. The meetings were recorded, transcribed and later analyzed from the dialectical method. The research methodology used was the participatory research. The TGA as teaching methodology provided the interaction between students of the discipline and the teacher/researcher. It also mobilized the students to search for information that would solve the problems related to heavy metals, as well as articulating such information, fomenting links among them and thus, conceive the concepts involved. At the moment of the discussion, it could be noticed the favoring of links related to: toxicity of metals and its effects in the human body; bioaccumulation and biomagnification, men's health, effect of human actions on the environment, impact of scientific knowledge in society and environment, the proposed identification and separation, among others. The moments of external speaking for the group, favored the students to organize their thinking and their understanding of concepts. This TGA was inserted into curriculum in the discipline and contributed to the assessment of students who received a grade in the form of Prática como Componente Curricular ("Practical Course as Curricular Component") item required in the political pedagogical project of the Chemistry Graduation Course.
\end{abstract}

Keywords: Teaching Guiding Activity; methodology; Qualitative Analytical Chemistry. 


\section{LISTA DE FIGURAS}

Figura 1. Relação entre Espimpolo (2013) e Sanchez (2014)

Figura 2: Estrutura da Atividade de Leontiev (1989)

36

Figura 3: Estrutura da AOE - adaptação de Espimpolo (2013)

37

Figura 4: Mediatização e o Ensino Tradicional em QAQ 45

Figura 5: Amostra teórica de metais. 66

Figura 6: Aluno A/1 mediador inicial da discussão 67

Figura 7: Continuação da rota - levar à secura $(\Delta$, símbolo aquecimento) 72

Figura 8: Visão geral da marcha analítica - destaque para os precipitados de chumbo e mercúrio I 79

Figura 9: Rota construída coletivamente 84

Figura 10: Formação da amálgama de cobre 85

Figura 11: Rota construída coletivamente anexada nas bancadas - destaque para volume médio utilizado 88 


\section{LISTA DE SIGLAS}

AOE: Atividade Orientadora de Ensino

CNE: Conselho Nacional de Educação

DEDIC: Departamento de Educação, Informação e Comunicação

DQ: Departamento de Química

EM: Ensino Médio

ETIM: Ensino Técnico Integrado ao Médio

EUA: Estados Unidos da América

FFCLRP: Faculdade de Filosofia, Ciências e Letras de Ribeirão Preto

IUPAC: International Union of Pure and Applied Chemistry

LDB: Lei de Diretrizes e Bases

LQ: Licenciatura em Química

MP: Metal Pesado

PAE: Programa de Aperfeiçoamento de Ensino

PCC: Prática como Componente Curricular

PPP: Projeto Político Pedagógico

QAQ: Química Analítica Qualitativa

USP: Universidade de São Paulo 


\section{SUMÁRIO}

1. INTRODUÇÃO

1.1 - Desafios no Ensino Superior e o curso de Licenciatura em Química (DQ/FFCLRP).

1.2 - A disciplina de QAQ e os grupos analíticos IV e V ........................................ 23

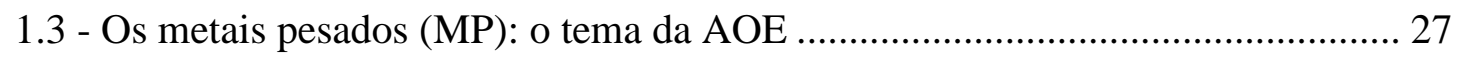

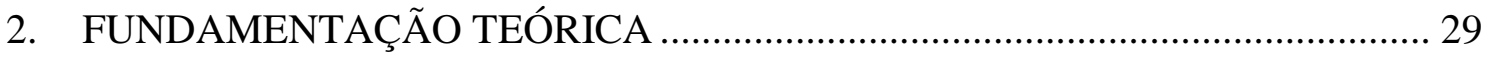

2.1 - Algumas considerações sobre o processo de objetivação/apropriação ............... 32

2.3 - A Teoria da Atividade e a Atividade Orientadora de Ensino (AOE) ................. 35

2.4 - Os conceitos e os processos psicológicos ....................................................... 39

2.5 - A AOE e nossa proposta em QAQ …......................................................... 44

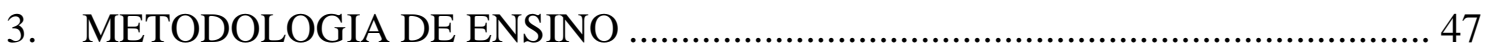

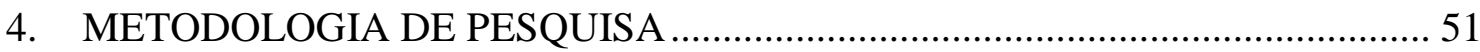

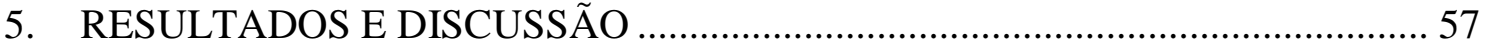

$1^{\mathrm{o}}$ Encontro (situação desencadeadora 1): Discussão sobre o conceito de metal pesado e o possível problema vinculado a sua presença em cosméticos e na natureza.......... 58

$2^{\circ}$ Encontro (situação desencadeadora 2): Proposta coletiva de rota de separação para

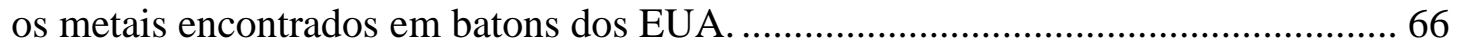

$3^{\circ}$ Encontro: Atividade experimental - separação e identificação dos metais de uma

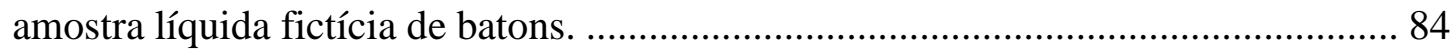

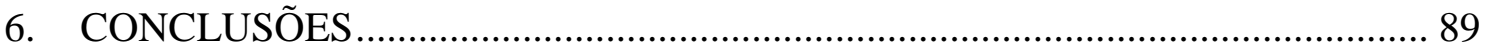

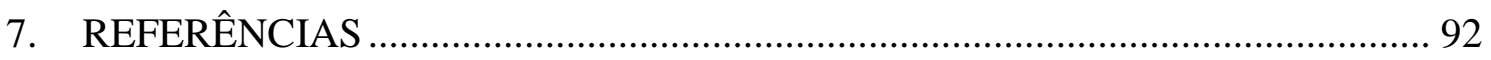

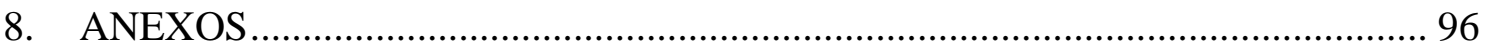

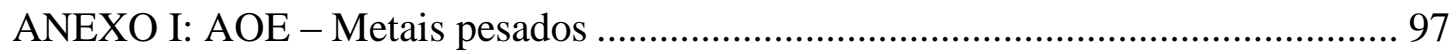

ANEXO II: Classificação Metais Pesados - Duffus (2002) ....................................... 98

CONTINUAÇÃO - ANEXO II: Classificações Metais Pesados - Duffus (2002)..... 99

ANEXO III: Solubilidade dos cloretos dos cátions do grupo V ............................. 100

ANEXO IV: Constante produto de solubilidade (Kps) para os sulfetos dos grupos III e IV 
ANEXO V: Distribuição de carga horária - Licenciatura em Química .....

CONTINUAÇÃO - ANEXO V: DISTRIBUIÇÃO DE CARGA HORÁRIA -

LICENCIATURA EM QUÍMICA 


\begin{abstract}
ANEXOS
ANEXO I: AOE - Metais pesados 97

ANEXO II: Classificação Metais Pesados - Duffus (2002). 98
\end{abstract}

CONTINUAÇÃO - ANEXO II: Classificações Metais Pesados - Duffus (2002)..... 99

ANEXO III: Solubilidade dos cloretos dos cátions do grupo V 100

ANEXO IV: Constante produto de solubilidade (Kps) para os sulfetos dos grupos III e IV. 101

ANEXO V: Distribuição de carga horária - Licenciatura em Química.. 102

CONTINUAÇÃO - ANEXO V: Distribuição de carga horária - Licenciatura em Química. 103 


\begin{abstract}
APRESENTAÇÃo
Sou Licenciado em Química pela Faculdade de Filosofia, Ciências e Letras de Ribeirão Preto, da Universidade de São Paulo (FFCLRP/USP) e em 2009 (último ano de minha graduação), iniciei minhas atividades de docência no Ensino Médio (EM) em uma escola particular de Ribeirão Preto.

No início de 2010 fui aprovado em um concurso público e além do EM, passei a ministrar aulas no Ensino Técnico Integrado ao EM (ETIM). No segundo semestre deste mesmo ano, também me tornei tutor online bolsista do curso de Licenciatura em Ciências oferecido pela USP em parceria com a Universidade Virtual do Estado de São Paulo (UNIVESP).
\end{abstract}

Neste começo da carreira, entendi que as disciplinas de cunho específico e pedagógico desenvolvidas durante o curso de Licenciatura, não eram estanques no que diz respeito ao processo de docência. Durante a graduação, fui orientado pela professora Daniela Gonçalves de Abreu e sempre estive engajado com a área de Ensino de Química de forma prática (projetos de extensão), mas ainda me faltava algo mais efetivo no âmbito de pesquisa.

Com o intuito de alçar novas experiências, em fevereiro de 2012, ingressei no mestrado sob orientação da professora Yassuko Iamamoto, que é responsável pela disciplina de Química Analítica Qualitativa (QAQ) há aproximadamente 30 anos. O Departamento de Química ainda não oferecia um programa de pós-graduação em Ensino, mas a referida professora possui uma preocupação e um comprometimento exemplar com esta área, além de orientar na parte específica (Bioinorgânica). Há muitos anos ela tem disponibilizado sua disciplina como objeto de estudo e há uma década tem colaboração com a Profa. Daniela Gonçalves de Abreu, que foi sua orientanda e hoje é docente da área de Ensino de Química.

Em 2013, em virtude de um credenciamento da professora Daniela Gonçalves de Abreu no programa de pós, transferimos oficialmente a orientação para a sua responsabilidade. Na verdade, posso dizer que tive o privilégio de ser orientado pelas duas professoras, desde o início de meu mestrado. A professora Yassuko me deu suporte na área específica de QAQ e a professora Daniela na área de Ensino.

Devido ao grande interesse pelo Ensino, meu projeto esteve vinculado à disciplina de QAQ oferecida para o curso de Licenciatura em Química (LQ) do Departamento de Química (DQ) pertencente à Faculdade de Filosofia, Ciências e Letras de Ribeirão Preto 
- FFCLRP. Nesta disciplina, na turma de 2013, desenvolvi (orientado por ambas as professoras), uma Atividade Orientadora de Ensino (AOE) para abordar os grupos analíticos IV e V (metais pesados). Na QAQ, também fui monitor durante três anos (2012, 2013 e 2014), participando das aulas práticas e teóricas, oferecendo monitorias semanais para esclarecer as dúvidas dos alunos relacionadas às práticas realizadas (Plantões de dúvidas). O objetivo destas monitorias foi intervir na aprendizagem dos alunos do curso de QAQ, particularmente nas atividades de laboratório. Em 2013, fui estagiário PAE e em 2014, atuei como voluntário do mesmo programa, participando assim da correção dos relatórios e demais atividades produzidas pelos alunos.

As experiências com a disciplina de QAQ me proporcionaram um amadurecimento no que diz respeito à interface área específica - área pedagógica. Pude perceber as dificuldades no ensino de química no ensino superior e me inquietar com a necessidade de testar metodologias diferentes na sala de aula, neste nível de ensino. Só a aula expositiva, ou expositiva dialogada e práticas de laboratório, não dão conta da aprendizagem.

Espimpolo (2013), já havia num momento anterior elaborado e desenvolvido uma Atividade Orientadora de Ensino, com o objetivo de investigar a construção do conhecimento em QAQ. Desta forma, já havíamos obtido resultados satisfatórios com a AOE na referida disciplina. Todavia, nesta Dissertação o objetivo é investigar com maiores critérios o potencial da AOE enquanto metodologia para a QAQ. Pretendemos neste momento, analisar a AOE em sua totalidade, ou seja, o processo incluindo as ações educativas e as aprendizagens proporcionadas. Este trabalho propõe elaborar uma atividade de ensino pautada em referenciais da teoria histórico-cultural e avaliar qual a sua verdadeira contribuição na aprendizagem de conceitos químicos relativos a metais pesados. Acreditamos que esta Dissertação contribuirá para o ensino de química no nível superior. 


\section{INTRODUÇÃO}

O desenvolvimento da prática docente é um fértil e complexo campo de análises e reflexões no que diz respeito aos seus sujeitos que estão em formação inicial ou continuada. Quando nos deparamos com cursos de formação de professores, a metalinguagem nos parece ser um ponto nevrálgico. Como formar especialistas em formação? Com “educar” futuros educadores?

Dentre a ampla possibilidade de discussão e pesquisa, acreditamos que o campo metodológico mereça um destaque especial para formação destes professores e que o movimento dialético entre o processo a ser construído e indícios da aprendizagem possa ser um importante parâmetro para o desenvolvimento de nossos estudos.

Deste modo, o presente trabalho investigou a potencialidade de uma metodologia diferenciada para a disciplina de Química Analítica Qualitativa, que é oferecida para o curso de Licenciatura em Química, do Departamento de Química da FFCLRP/USP.

\section{1 - Desafios no Ensino Superior e o curso de Licenciatura em Química (DQ/FFCLRP)}

A Educação no Brasil possui raízes arraigadas em modelos europeus, como o denominado modelo jesuítico advindo do sistema universitário Francês e o modelo Alemão. Neste primeiro, o conhecimento era obtido como algo acabado a ser repassado por meio da repetição. Os alunos pertencentes a este método (denominado escolástico) apresentavam uma postura passiva de "recebimento de informações", memorização e reprodução mecânica no momento da avaliação. Assim, priorizava-se a inserção fechada de conteúdos a serem estudados, bem como a nitidez de conceitos e definições sem questionamentos ou reflexões (ANASTASIOU, 2001).

O Ensino Superior no Brasil teve seu início ainda no período colonial, onde o modelo francês-napoleônico havia sido adotado. Para este, a prioridade estava centrada na formação técnica e profissionalizante com o intuito de formar burocratas para desempenhar funções para o Estado. Este modelo corroborava com o jesuítico, reforçando a aceitação não reflexiva das atividades impostas, a serem memorizadas. 
Infelizmente, alguns destes elementos ainda são atuais no cotidiano escolar (ANASTASIOU, 2001).

Além das limitações metodológicas herdadas dos sistemas europeus, o ensino brasileiro apresenta ainda uma gama de desafios tradicionalmente conhecidos pela sociedade atual. Desvalorização, sucateamento, indisciplina, má formação de profissionais e salários ruins, são alguns dos problemas enfrentados.

Mesmo com a proliferação de programas de pós-graduação no campo educacional, sabe-se que o conhecimento produzido pelas Universidades ainda encontra resistências de acesso a Escola Básica. A pesquisa pode ser considerada uma importante ferramenta para a melhoria do ensino e da aprendizagem, mas é imperativa a necessidade de adaptações para que o êxito ocorra por meio da utilização de resultados pesquisados e obtidos.

Para Severino (2001),

A pesquisa acaba assumindo uma tríplice dimensão. De um lado, tem uma dimensão epistemológica: a perspectiva do conhecimento. Só se conhece construindo o saber, ou seja, praticando a significação dos objetos. De outro lado, assume ainda uma dimensão pedagógica: a perspectiva decorrente de sua relação com a aprendizagem. Ela é a mediação necessária para o processo de ensino/aprendizagem. Só se aprende e só se ensina pela efetiva prática da pesquisa. Mas ela tem ainda uma dimensão social: a perspectiva da extensão (p. 21).

Deste modo, acreditamos que a deficiência de uma ou mais parcelas desta tríplice dimensão, venha a contribuir para a perda da eficácia do processo investigativo e consequente desvalorização da prática adotada.

Seguindo nesta linha de reflexão, algumas questões (inquietações), vieram à tona: $\mathrm{O}$ que tem sido pesquisado no Ensino Superior está inclinado à melhoria do mesmo? Até que ponto as teorias educacionais adotadas são efetivas para a prática docente? Qual será a densidade das dimensões epistemológicas, pedagógicas e sociais das pesquisas desenvolvidas neste nível? Qual o desdobramento das pesquisas em educação para a Escola Básica? E mais: qual tem sido o impacto das pesquisas em educação na sala de aula no Ensino Superior, responsável pela formação de professores? 
Duarte (1992), afirma que:

(...) para que as teorias educacionais críticas possam dirigir de forma efetiva a prática dos educadores, é preciso que a própria concepção do que seja uma teoria crítica não se limite ao âmbito dos fundamentos filosóficos, sociológicos e históricos da educação. Quando isso ocorre, os educadores acabam sendo levados, inevitavelmente a "completar" o espaço vazio (ou ao menos rarefeito) entre esse âmbito e o das propostas pedagógicas, procurando elementos teóricos mediadores que lhes auxiliem a explicar o processo educativo propriamente dito (p.6).

Assim, entendemos que existe ainda determinada lacuna a ser "preenchida". Há a necessidade de uma mediação mais eficaz entre os fundamentos teóricos e a prática educativa que possa favorecer, integrar e estimular o conhecimento a ser produzido ao cotidiano escolar dos educadores.

Desta forma, acreditamos que a Universidade possui função ímpar junto a este propósito de mediação, ao passo que é fonte de construção coletiva do conhecimento, bem como da sua divulgação e fundamentação.

Ao consultar a Lei de Diretrizes e Bases da Educação Nacional (LDB, Lei n ${ }^{\circ}$ 9.394, de 20 de dezembro de 1996), a despeito do papel das Instituições de Ensino Superior junto a esta função, encontramos no capítulo 4 (artigo 43 - III a VI), algumas denominações reproduzidas a seguir.

Seria papel da Universidade:

(...) III- incentivar o trabalho de pesquisa e investigação científica, visando o desenvolvimento da ciência e da tecnologia e da criação e difusão da cultura, e, desse modo, desenvolver o entendimento do homem e do meio em que vive;

IV-promover a divulgação de conhecimentos culturais, científicos e técnicos que constituem patrimônio da humanidade e comunicar o saber através do ensino, de publicações ou de outras formas de comunicação;

$V$-suscitar o desejo permanente de aperfeiçoamento cultural e profissional e possibilitar a correspondente concretização, integrando os conhecimentos que vão 
sendo adquiridos numa estrutura intelectual sistematizadora do conhecimento de cada geração;

VI- estimular o conhecimento dos problemas do mundo presente, em particular os nacionais e regionais, prestar serviços especializados à comunidade e estabelecer com esta uma relação de reciprocidade;

A integração dos conhecimentos produzidos, a prestação de serviços especializados e o estabelecimento de uma relação de reciprocidade com a sociedade, são fatores os quais encontramos resistências. Muitas vezes, existe a limitação em se relacionar os conhecimentos (considerados específicos e pedagógicos) dentro das próprias instituições de Nível Superior, quiçá galgar a integração com a comunidade e consequente Escola Básica.

Em linhas gerais, quando nos referimos aos cursos de graduação, uma divisão inicial é estabelecida entre os denominados cursos de Bacharelado e os cursos de Licenciatura. Enquanto a primeira carreira apresenta o foco voltado para a indústria e/ou pesquisa vinculado à área determinada "específica", os cursos de Licenciatura são oferecidos com o intuito de possibilitar a formação de professores para a Educação tradicional e consequente possibilidade de pesquisa em Ensino.

Todavia, a organização destes cursos de Licenciatura também se dá por meio de uma subdivisão entre as suas disciplinas consideradas específicas e pedagógicas. Enquanto o primeiro tipo de disciplinas proporciona o conhecimento de uma base nacional comum de conceitos e conteúdos, o segundo tipo favorece discussões acerca das didáticas que são arraigadas no contexto escolar.

$\mathrm{Na}$ formação de professores, além da dificuldade de diálogo entre a área dita como "dura" (disciplinas de química, física e cálculo) e a área pedagógica (disciplinas da área de Educação), também há dificuldade destas na relação com as escolas de ensino médio, na qual os alunos realizam estágios.

No contexto do curso de Licenciatura em Química, oferecido pelo Departamento de Química (DQ), da Faculdade de Filosofia, Ciências e Letras de Ribeirão Preto (FFCLRP), as disciplinas foram organizadas conforme as orientações do "Programa de Formação de Professores - USP" e as recomendações do Conselho Nacional da Educação. 
O currículo foi subdivido em quatro grandes grupos de disciplinas e atividades a serem desenvolvidas ao longo de 10 semestres, com o intuito de propiciar uma ampla e sólida formação docente (Quadro1).

\begin{tabular}{|c|c|c|}
\hline BLOCO & & DISCIPLINAS \\
\hline $\begin{array}{l}\text { Bloco I } \\
(1860 \mathrm{~h})\end{array}$ & $\begin{array}{l}\text { Formação } \\
\text { Específica } \\
\text { (Disciplinas e } \\
\text { atividades } \\
\text { diretamente } \\
\text { relacionadas aos } \\
\text { conhecimentos } \\
\text { das áreas de } \\
\text { Química, Física } \\
\text { e Matemática) }\end{array}$ & $\begin{array}{l}\text { 1. Química Geral Experimental - 8a - DQ } \\
\text { 2. Iniciação à Química - 8a - DQ } \\
\text { 3. Noçôes de Segurança em Laboratórios de Química - 2a } \\
\text { - DQ } \\
\text { 4. Cálculo Diferencial e Integral I - 4a - DCM } \\
\text { 5. Cálculo Diferencial e Integral II - 4a - DCM } \\
\text { 6. Geometria Analítica - 2a - DCM } \\
\text { 7. Física I para Licenciatura - 6a - DF } \\
\text { 8. Química Analítica Qualitativa - 6a -DQ* } \\
\text { 9. Complementos de Matemática para a Química -2a - } \\
\text { DCM } \\
\text { 10. Física II para a Licenciatura - 4a - DF } \\
\text { 11. Mineralogia - 2a - DQ } \\
\text { 12. Química Analítica Quantitativa - 6a -DQ } \\
\text { 13. Físico-Química I: Físico Química de Equilíbrio - 4a-DQ } \\
\text { 14. Física III - 4a -DF } \\
\text { 15. Química Inorgânica I - 4a - DQ } \\
\text { 16. Físico-Química II: Físico-Química Dinâmica - 4a - DQ } \\
\text { 17. Introdução à Química Quântica - 4a -DQ } \\
\text { 18. Química Orgânica I - 4a - DQ } \\
\text { 19. Química Orgânica II - 4a - DQ } \\
\text { 20. Química Inorgânica II - 4a -DQ } \\
\text { 21. Bioquímica Teórica I - 2a - DQ } \\
\text { 22. Química Orgânica III - 4a - DQ } \\
\text { 23. Físico-Química Experimental - 6a - DQ } \\
\text { 24. Química Inorgânica Experimental - 4a - DQ } \\
\text { 25. Bioquímica Teórica II -2a - DQ } \\
\text { 26. Química Orgânica Experimental - 6a - DQ } \\
\text { 27. Métodos Instrumentais - 6a - DQ } \\
\text { 28. Química do Meio Ambiente - 2a - DQ } \\
\text { 29. Bioquímica Experimental - - - - DQ } \\
\text { 30. Introdução ao Curso de Licenciatura em Química - 2a - } \\
\text { DQ }\end{array}$ \\
\hline $\begin{array}{l}\text { Bloco II } \\
(240 \mathrm{~h})\end{array}$ & $\begin{array}{l}\text { Iniciação à } \\
\text { Licenciatura } \\
\text { (Disciplinas e } \\
\text { atividades } \\
\text { introdutórias à } \\
\text { formação do } \\
\text { professor da } \\
\text { Educação } \\
\text { Básica) }\end{array}$ & $\begin{array}{l}\text { 1. História da Química - 2a/1t }-\mathrm{DQ} \\
\text { 2. Atividades Científico Culturais - } 2 \mathrm{a} / 2 \mathrm{t}-\mathrm{DQ} \\
\text { 3. Introdução aos Estudos da Educação em Ciências - } \\
\text { 2a/1t - DQ } \\
\text { 4. Introdução aos Estudos Sobre Educação - 2a - DEDIC }\end{array}$ \\
\hline $\begin{array}{l}\text { Bloco III } \\
(510 \mathrm{~h})\end{array}$ & $\begin{array}{l}\text { Fundamentos } \\
\text { Teóricos e } \\
\text { Práticos da } \\
\text { Educação } \\
\text { (Disciplinas e } \\
\text { atividades } \\
\text { relacionadas à }\end{array}$ & $\begin{array}{l}\text { 1. Política e Gestão Educacional no Brasil - 4a/1t - DEDIC } \\
\text { 2. Psicologia Educacional - 4a/2t - DEDIC } \\
\text { 3. Didática Geral I - 4a/2t - DEDIC } \\
\text { 4. Supervisão Integrada de Estágio I - 2a - DEDIC } \\
\text { 5. Supervisão Integrada de Estágio II - 2a - DEDIC } \\
\text { 6. Supervisão Integrada de Estágio III - 2a - DEDIC } \\
\text { 7. Introdução à Língua Brasileira de Sinais - 2a - DEDIC }\end{array}$ \\
\hline
\end{tabular}




\begin{tabular}{|c|c|c|}
\hline & $\begin{array}{l}\text { formação } \\
\text { pedagógica em } \\
\text { geral) }\end{array}$ & $\begin{array}{l}\text { 8. Metodologia Científica da Pesquisa em Ensino de } \\
\text { Química e de Ciências - 2a/1t - DQ }\end{array}$ \\
\hline $\begin{array}{l}\text { Bloco IV } \\
(630 \text { h) }\end{array}$ & $\begin{array}{l}\text { Fundamentos } \\
\text { Metodológicos } \\
\text { do Ensino } \\
\text { (Disciplinas e } \\
\text { atividades } \\
\text { relacionadas ao } \\
\text { ensino de } \\
\text { Química e } \\
\text { Ciências) }\end{array}$ & $\begin{array}{l}\text { 1. Metodologia do Ensino em Química I 2a/1t - DEDIC } \\
\text { 2. Metodologia de Ensino em Química II 2a/1t - DEDIC } \\
\text { 3. Didática das Ciências - 2a/1t - DEDIC } \\
\text { 4. Química para o Ensino Médio I - 2a/1t - DQ } \\
\text { 5. Química para o Ensino Médio II- 2a/2t - DQ } \\
\text { 6. Monografia em Ensino de Química e de Ciências I - } \\
\text { 2a/2t - DQ } \\
\text { 7. Monografia em Ensino de Química e de Ciências II - } \\
\text { 2a/2t - DQ } \\
\text { 8. Atividades Integradas de Estágio - 2a/2t - DEDIC } \\
\text { 9. Monografia Supervisionada em Ensino de Química e de } \\
\text { Ciências-2a - DQ }\end{array}$ \\
\hline
\end{tabular}

Quadro1. Distribuição em blocos das disciplinas do curso de Licenciatura em

Química oferecido no período noturno pelo DQ da FFCLRP-USP. Fonte: Projeto Político Pedagógico (PPP) - Licenciatura em Química - disponível em http://www.ffclrp.usp.br/graduacoes/quimica/licenciaturaemquimica.php

Nesta divisão, o primeiro grupo foi reservado às disciplinas de "Formação Específica" e é constituído por trinta disciplinas de Química, Física e Matemática. Neste, está contida a disciplina de QAQ com a carga horária semanal de 6 aulas (em negrito no Quadro 1). Comumente, os alunos possuem grandes dificuldades de aprendizagem nas disciplinas deste bloco.

O segundo grupo intitulado de "Iniciação à Licenciatura", dispõe de quatro disciplinas gerais, sendo três ofertadas pelo DQ e uma pelo Departamento de Educação, Informação e Comunicação (DEDIC). Estas disciplinas são apresentadas com o objetivo de discutir as problemáticas da educação e do ensino de ciências, além de promover o desenvolvimento de atividades científicase culturais.

O terceiro grupo denominado "Fundamentos Teóricos e Práticos da Educação" é composto por quatro disciplinas sob a responsabilidade do DEDIC e que estão vinculadas aos estágios, além de três disciplinas que abrangem a supervisão integrada dos estágios. Estes são desenvolvidos a partir do $5^{\circ}$ semestre do curso e abrem caminho para o contato do licenciando com o seu futuro local de trabalho.

Por fim, o quarto grupo intitulado "Fundamentos Metodológicos do Ensino" é composto por oito disciplinas, sendo quatro delas ofertadas pelo DEDIC e quatro de responsabilidade do DQ. Este bloco contempla disciplinas como "Química para o Ensino Médio I e II", “Monografia em Ensino de Química e Ciências e I e II" entre 
outras, que visam desenvolver junto ao licenciando, reflexões acerca dos saberes e práticas de Ensino, vinculando a áreas pedagógicas e específicas, por meio de estágios supervisionados e monografia de conclusão de curso a ser desenvolvida no DQ e nas escolas básicas (PPP, Licenciatura em Química, 2013).

Respaldados pela proposta para os cursos de formação de professores da Educação Básica em nível superior nos incisos I, II, III e IV da resolução do Conselho Nacional de Educação (CNE/CP 2/2002), um total de 400 horas foi distribuído entre as disciplinas de cunho específico e pedagógico, destinadas a "Prática como Componente Curricular" (PCC). Esta atividade que compõe $10 \%$ da nota final de cada disciplina é desenvolvida com o intuito de proporcionar uma articulação entre os conteúdos específicos e sua importância na Escola tradicional.

Como dito anteriormente, a disciplina de QAQ faz parte do primeiro grande grupo (disciplinas de formação específica) e tem sido alvo de pesquisas na área de ensino. Estas pesquisas tem favorecido a reflexão sobre a formação do Licenciando e o Ensino de Química nos primeiros semestres do curso.

Abaixo, faremos uma breve apresentação da QAQ com o intuito de delinear nosso campo empírico.

\section{2 - A disciplina de QAQ e os grupos analíticos IV e V}

Dentre as disciplinas do núcleo básico oferecidas pelos cursos de graduação em Química (Licenciatura e Bacharelado) do Departamento de Química, da Faculdade de Filosofia, Ciências e Letras de Ribeirão Preto (DQ/FFCLRP/USP), a disciplina de Química Analítica Qualitativa (QAQ), tem sido considerada, pelas Instituições de Ensino Superior do Brasil, como essencial para a formação de um Químico. Tal disciplina aborda o equilíbrio químico em solução aquosa e a análise química qualitativa de amostras "desconhecidas", nos estados sólidos e líquidos. O trabalho desenvolvido com amostras desconhecidas pode contribuir para despertar nos estudantes um perfil investigativo. Os fundamentos históricos da QAQ estão pautados na análise da pureza de metais como ouro e prata e a consequente prevenção de falsificações (ALVIM e ANDRADE, 2006). 
No Brasil, os precursores da análise qualitativa, foram Heinrich Rheinboldt (1891-1955), da Universidade de Bonn (Alemanha) e Paschoal Senise (1917 - 2011), um de seus primeiros discípulos. O professor Henrich Rheinboldt chegou a São Paulo em julho de 1934, contratado para ser o responsável e o organizador do curso de química da USP. Iniciou as atividades didáticas em 1935, na então "Subsecção de Ciências Químicas" e, posteriormente no Departamento de Química da Faculdade de Filosofia, Ciências e Letras da Universidade de São Paulo. Ele priorizava as aulas de laboratório por acreditar que o fundamento do ensino de Química era a intuição e que o aluno, para aprender a pensar, deveria vivenciar os fenômenos até se familiarizar com eles (SENISE, 2006).

A disciplina QAQ, no contexto do DQ/FFCLRP/USP, sofreu ao longo dos anos uma redução de sua carga horária, que era de 11 horas semanais (1990) para 6 horas semanais (2001). Esta diminuição foi devida a inclusão de novas disciplinas na grade do curso de Química que correlacionam algumas áreas, como a disciplina de Química Ambiental e de Tratamento de Resíduos Químicos de Laboratórios de Ensino e Pesquisa. A inserção destas disciplinas permitiu a flexibilização do currículo segundo as orientações da Lei de Diretrizes e Bases da Educação Nacional (LDB) (BRASIL, 1996).

Com o intuito de se manter a qualidade do ensino nesta nova carga horária da disciplina, nos últimos dez anos algumas reestruturações foram desenvolvidas por meio da produção de um "manual de laboratório" para ser utilizado durante os experimentos, como alternativa aos livros tradicionais (por exemplo, VOGEL, 1981 e BACCAN, 1997). Algumas atividades foram inseridas no curso de Química, como o tratamento de resíduos produzidos pela disciplina e a discussão de temas que possibilitassem a contextualização, no Ensino Médio, de conteúdos relacionados à QAQ (ABREU, 2003 e 2006).

Na dissertação de mestrado de Espimpolo (2013) foi planejada uma Atividade Orientadora de Ensino (AOE) para investigar o processo de construção do conhecimento de alguns conceitos. A AOE foi desenvolvida de forma extracurricular para um grupo de alunos da QAQ. Este estudo inspirou e subsidiou o presente trabalho, à medida que indicou a possível potencialidade da AOE como recurso didáticometodológico na disciplina, despertando-nos o interesse de pesquisa. 
A figura 1 abaixo simboliza o movimento dialético entre a proposta de Espimpolo (2013) e a nossa:

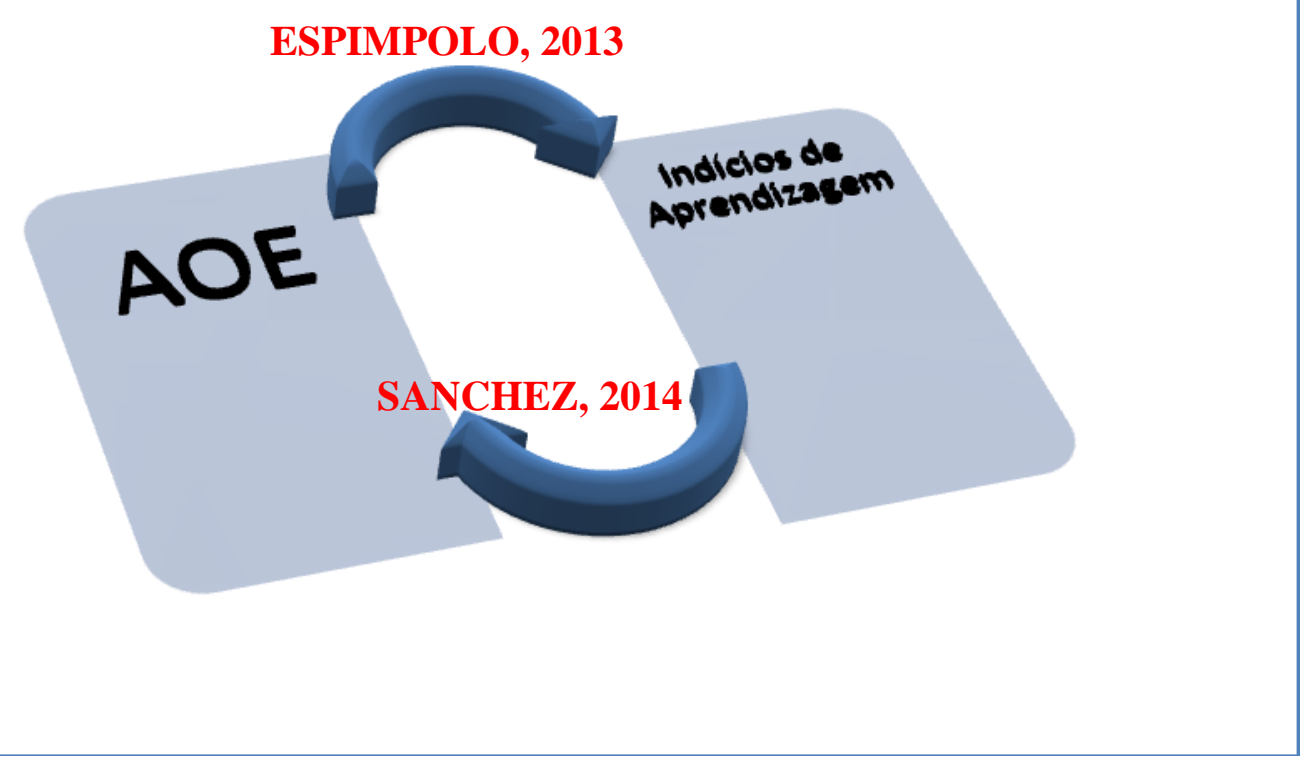

Figura 1. Relação entre Espimpolo (2013) e Sanchez (2014)

Assim, ao passo que Espimpolo (2013) investigou a aprendizagem de alguns conceitos de QAQ por meio de uma AOE, nós investigamos a potencialidade da AOE como recurso didático metodológico na mesma disciplina, por meio de indícios da aprendizagem de determinados conceitos. Mas qual(is) conceito(s) escolher?

Com a redução da carga horária de QAQ, alguns grupos analíticos (grupos IV e V - Metais Pesados), foram aos poucos, deixando de ser abordados no curso de Licenciatura e Bacharelado em Química, ofertados pelo DQ. No caso específico da Licenciatura, o curso ainda é oferecido no período noturno, e dispõe de um tempo menor para o desenvolvimento das atividades, em relação ao Bacharelado que é oferecido em período integral.

No tópico 1.3 deste trabalho, faremos uma discussão acerca dos metais pesados. Devido a sua importância conferida na atualidade, acreditamos que estes não poderiam ser suprimidos do currículo do nosso curso e por isso, também foram escolhidos como temática para a nossa proposta de atividade.

De forma geral, o desenvolvimento da QAQ é baseado na análise qualitativa de amostras líquidas e sólidas. Através de reações químicas, cátions são separados em 
grupos e subgrupos até o isolamento e a identificação de cada um deles. Dentre as técnicas possíveis de identificação, pode-se destacar a formação de precipitado, mudança de cor, produção/ liberação de gás, etc.

De acordo com suas afinidades, os referidos cátions foram divididos em cinco grupos analíticos de forma a facilitar suas respectivas análises. Com exceção do grupo I, formado por $\mathrm{Na}^{+}, \mathrm{K}^{+}$e $\mathrm{NH}_{4}^{+}$(íons sódio, potássio e amônio), todos os demais grupos possuem um reagente precipitante comum (reagente de grupo), que formam compostos insolúveis, favorecendo a separação e posterior identificação.

A sequência de classificação (Quadro 2), proposta inicialmente por Karl Remeglus Fresenius (1879) foi adotada no Brasil por Rheinboldt e é fundamentada na gradativa complexidade das reações à medida que os grupos são estudados.

\begin{tabular}{|c|c|c|}
\hline GRUPOS & $\begin{array}{c}\text { REAGENTE } \\
\text { PRECIPITANTE } \\
\text { DE GRUPO }\end{array}$ & CÁTIONS CONSTITUINTES \\
\hline I & $\begin{array}{c}\text { Não possui reagente } \\
\text { de grupo }\end{array}$ & $\mathrm{Na}^{+}, \mathrm{K}^{+}, \mathrm{NH}_{4}{ }^{+}$ \\
\hline II & $\mathrm{CO}_{3}^{2-}$ & $\mathrm{Mg}^{2+}, \mathrm{Ba}^{2+}, \mathrm{Ca}^{2+} \mathrm{e} \mathrm{Sr}^{2+}$ \\
\hline III & $\mathrm{S}^{2-}$ em meio básico & $\mathrm{Fe}^{3+}, \mathrm{Al}^{3+}, \mathrm{Cr}^{3+}, \mathrm{Ni}^{2+}, \mathrm{Co}^{2+}, \mathrm{Zn}^{2+} \mathrm{e} \mathrm{Mn}^{2+}$ \\
\hline IVA & $\mathrm{S}^{2-}$ em meio ácido & $\mathrm{Hg}^{2+}, \mathrm{Pb}^{2+}, \mathrm{Bi}(\mathrm{III}), \mathrm{Cu}^{2+} \mathrm{e} \mathrm{Cd}^{2+}$ \\
\hline IVB & $\mathrm{S}^{2-}$ em meio ácido & $\mathrm{As}(\mathrm{III}), \mathrm{As}^{2+}(\mathrm{V}), \mathrm{Sb}(\mathrm{III}), \mathrm{Sb}^{2}\left(\mathrm{~V}^{2}\right), \mathrm{Sn}^{2+} \mathrm{e} \mathrm{Sn}^{4+}$ \\
\hline V & Cl & $\mathrm{Ag}^{+}, \mathrm{Pb}^{2+} \mathrm{e} \mathrm{Hg}_{2}{ }^{2+}$ \\
\hline
\end{tabular}

Quadro 2. Classificação dos cátions proposta por Fresenius (1879), reagente de grupo e os cátions constituintes de cada grupo

A AOE proposta neste trabalho foi estruturada por meio de uma notícia atual (publicada na revista "Environmental Health Perspectives"), que relatava a presença de metais pesados em batons e cosméticos nos EUA, cujo tema coincide com os grupos IV e V de QAQ. 


\section{3 - Os metais pesados (MP): o tema da AOE}

Os metais pesados (MP) são de grande importância na contemporaneidade. É comum em nosso dia-a-dia, encontrar notícias destes metais vinculadas a algum desastre ambiental, químico ou em informações de utilidade pública. Entretanto, o que temos observado é a gama de definições e contradições que a discussão do tema pode revelar.

Em uma reportagem atual (janeiro/2014), a tinta para tatuagem da marca "supreme" foi proibida de ser comercializada por conter MP tóxicos. A notícia cita os metais chumbo, cádmio e mercúrio e generaliza como "pesados" o nióbio e o titânio, também encontrados na composição da tinta. Parece que até para os elementos químicos vale o ditado: "Diga-me com quem andas e te direi quem és".

http://g1.globo.com/bemestar/noticia/2014/01/anvisa-determina-apreensao-detintas-para-tatuagem-da-marca-supreme.html

Nesse sentido, pretendemos fazer uma rápida discussão acerca de assunto tão presente em nosso cotidiano e que muitas vezes, apresenta definições distorcidas. Mas como podemos definir um MP?

A evolução das pesquisas, dos termos e critérios científicos tem favorecido a multiplicidade de definições. De forma geral, o termo está associado a metais que possuem elevada massa específica, massa atômica, número atômico, ou ainda, elevada densidade (BAIRD, 2004). Além desta classificação, a formação de sulfetos e hidróxidos insolúveis, bem como a formação de sais e complexos coloridos também tem sido parâmetros para se definir estes metais (HAWKES, 1997).

Duffus (2002) realizou um levantamento bibliográfico sobre as significações de MPs encontradas nas últimas décadas, cujo relatório foi apresentado à União Internacional de Química Pura e Aplicada (IUPAC). Neste, foi evidenciado que publicações e legislações consideram MPs, o grupo de metais e semimetais associados a contaminações, toxicidades e ecotoxicidades. O autor ainda constatou que existem variações com relação à classificação o que gera uma incerteza do termo. Segundo ele, há uma tendência de se denominar "metal pesado" todos os metais que possuem alta toxicidade. Assim, seria ideal uma reclassificação que levasse em consideração a linguagem em termos químicos, biológicos e tóxicos (CHAE, 2007).

O quadro 3, abaixo reproduzida de Duffus (2002), apresenta algumas definições a cerca dos metais. 


\begin{tabular}{|l|l|}
\hline Termo & Comentários \\
\hline Metal & $\begin{array}{l}\text { Os metais podem ser definidos pelas propriedades físicas do estado elementar, } \\
\text { como elementos com brilho metálico, com capacidade de perder elétrons e } \\
\text { formar íons positivos e a capacidade de conduzir calor e eletricidade. }\end{array}$ \\
\hline Semimetal & $\begin{array}{l}\text { Um elemento que tem a aparência física e as propriedades de um metal, mas se } \\
\text { comporta quimicamente, como um não metal. }\end{array}$ \\
\hline Metal leve & $\begin{array}{l}\text { Um termo muito impreciso usado livremente para se referir a ambos o elemento } \\
\text { e os seus compostos. Raramente foi definido, mas o criador do termo, Bjerrum } \\
\text { (1936), aplicou a metais de densidade inferior a 4 g/cm-3. }\end{array}$ \\
\hline Metal pesado & $\begin{array}{l}\text { Um termo muito impreciso, usado livremente para se referir tanto o elemento e } \\
\text { os seus compostos. Baseia-se na classificação por densidade, que é raramente } \\
\text { uma propriedade biologicamente significativa. Há varias classificações (Anexo } \\
\text { II). De forma geral, metal com uma densidade superior a 4,0 g/cm }{ }^{-3} \text { (Grant, } \\
\text { 1987) ou superior a 4,5 g/cm-3 (Streit, 1994). }\end{array}$ \\
\hline Metal essencial & $\begin{array}{l}\text { Em termos gerais, um que é necessário para o ciclo de vida completo de um } \\
\text { organismo, cuja ausência produz sintomas de deficiência específicas aliviados } \\
\text { apenas por esse metal, e cujo efeito deve ser encaminhado a uma curva dose- } \\
\text { resposta }{ }^{1} \text {. }\end{array}$ \\
\hline Metal tóxico & $\begin{array}{l}\text { Um termo impreciso. A regra fundamental da toxicologia (Paracelsus, 1493- } \\
1541) \text { é que todas as substâncias, incluindo o carbono e de todos os outros } \\
\text { elementos e seus derivados; são tóxicos dada uma dose alta o suficiente. O } \\
\text { grau de toxicidade de metais varia grandemente de metal para metal e de } \\
\text { organismo para organismo. Metais puros são raramente, ou nunca, muito tóxica } \\
\text { (exceto como pós muito finos, o que pode ser prejudicial para os pulmões a } \\
\text { partir de qualquer que seja substância podem ser originários). Toxicidade como } \\
\text { essencialidade, deve ser definida por referência a uma curva dose-resposta para } \\
\text { a espécie em questão. }\end{array}$ \\
\hline
\end{tabular}

Quadro 3. Termos frequentemente utilizados para classificar os metais em estudos biológicos e ambientais - Fonte: Duffus, 2002.

Assim, podemos generalizar e reproduzir aquela máxima popular em que é dito que "a diferença entre o remédio e o veneno está na concentração administrada a

\footnotetext{
${ }^{1}$ Curva dose-resposta: Gráfico que relaciona a concentração de determinada substância no seu local de ação com o efeito farmacológico produzido.

Fonte: http://www.ufjf.br/farmacologia/files/2013/05/FI-AULA-4-FARMACODINAMICA.pdf
} 
determinado sistema ou organismo". E poderíamos ainda adicionar que "variações significativas de organismo para organismo" devem ser consideradas.

Outro fator importante a se ponderar é a forma na qual o elemento metálico está disponibilizado, ou seja, a sua especiação química. Na classificação dos perigos relacionados a determinado metal encontrado no meio, devemos levar em consideração o modo de transporte e a biodisponibilidade, fatores subordinados à especiação (BARRA et al, 2000). Dependendo da condição química deste metal, ele poderá ser absorvido ou não pelos organismos e consequentemente ser considerado ou não como pesado e cumulativo. A forma mais nociva destes metais se dá por meio de suas ligações a compostos orgânicos ou a sua apresentação como cátions (partículas positivas de grande reatividade).

Então entendemos que além da especiação química, a concentração também é um fator determinante para que determinado metal seja considerado tóxico. Entretanto, precisamos ressaltar que nem sempre um metal considerado tóxico é classificado como pesado.

Por conseguinte, diante da importância do tema citado e da necessidade de se desenvolver metodologias diferenciadas para uma disciplina tradicional com relevância ímpar para a formação de um futuro professor (e químico), é que este trabalho nos pareceu plausível.

Destarte, foi nosso foco investigar a potencialidade de Atividade Orientadora de Ensino (AOE) (Moura, 1992) como alternativa metodológica na disciplina de Química Analítica Qualitativa, oferecida aos estudantes matriculados no terceiro semestre de um curso de Licenciatura em Química. O tema desta AOE é referente aos conteúdos de dois grupos específicos (grupos IV e V) de metais abordados na QAQ que deverá ser traduzido em conceitos a serem apropriados pelos estudantes.

\section{FUNDAMENTAÇÃo TEÓRICA}

Pressupomos que a análise do processo de ensino como um todo estaria vinculada a indícios de aprendizagem e que este processo poderia ser orientado por um objeto específico. O desenvolvimento e a mediação deste processo poderiam favorecer ainda, a abstração e a generalização de determinado conceito. 
A teoria Histórico-Cultural pautada nos estudos de Vygotsky (1896-1934) considera a aprendizagem como atividade social. O caráter social da aprendizagem a torna passível de interação, de mediação e de orientação por meio de um objeto (NUNEZ, 2009, p. 25).

Assim, o referencial teórico deste trabalho apoiou-se nesta perspectiva, que foi defendida por alguns autores soviéticos. Além de Vygotsky, destacamos também Leontiev, que nomearam o conceito de atividade, vinculado a determinadas necessidades, como um dos princípios fundamentais ao estudo do desenvolvimento do psiquismo humano. A consciência e a atividade puderam ser compreendidas enquanto unidade dialética e foram consideradas essenciais a este modelo.

Vygotsky fez uso do conceito de atividade e aludiu que a atividade socialmente significativa é o princípio explicativo da consciência (movimento do externo para o interno) mediada por interações sociais. A apropriação dos conceitos e significações históricos da humanidade é possibilitada por meio deste movimento que vai do social ao individual (Moura, 2010, p. 83).

Leontiev também (1978) alvitrou-se a pesquisar como a estrutura da consciência do homem se modifica em relação à estrutura da atividade desenvolvida. $\mathrm{O}$ referido autor investigou o desenvolvimento do psiquismo a partir do que ele chamou de atividade principal ao longo da vida do sujeito. Esta atividade muda à medida que o mesmo passa a desempenhar funções diferentes no meio em que está inserido. As atividades principais estudadas por Leontiev foram: o jogo desenvolvido na idade préescolar, o estudo adolescido na idade escolar e o trabalho desempenhado na vida adulta.

Também merece destaque os estudos de Galperin (1902-1988), que foi colaborador de Vygotsky e Leontiev nos estudos acerca da possibilidade de interiorização das ações externas em internas, também denominada "Teoria da Assimilação" (NUNEZ, 2009, p. 92). Assim, Vygotsky, Leontiev e Galperin, trouxeram importantes contribuições no que diz respeito à organização do processo de ensino e aprendizagem, que foram traduzidos por Nunez (2009), como “princípios didáticos”.

Alguns destes princípios, estão apresentados no Quadro 4 a seguir e agregaram suporte teórico à discussão de nossos resultados. Todos os princípios estão minuciosamente discutidos em Nunez (2009, pp. 132 - 148). 


\begin{tabular}{|c|c|}
\hline PRINCÍPIO & IDEIA CENTRAL \\
\hline Do caráter científico de ensino & $\begin{array}{l}\text { "reflexo dialético mental, por meio da ascensão } \\
\text { do pensamento abstrato ao concreto - via } \\
\text { fundamental, mas não única" (p. 134). }\end{array}$ \\
\hline Do ensino que desenvolve & $\begin{array}{l}\text { "desenvolvimento integral da personalidade do } \\
\text { aluno, um ensino que não se esgota na } \\
\text { aprendizagem de um único conteúdo" (p.138). }\end{array}$ \\
\hline Do caráter consciente da atividade & $\begin{array}{l}\text { "A consciência da atividade permite a auto } \\
\text { regulação da aprendizagem, para o } \\
\text { desenvolvimento de estratégias de aprender a } \\
\text { aprender" (p. 138). }\end{array}$ \\
\hline Do caráter objetal da atividade & $\begin{array}{l}\text { “a interação com determinados objetos } \\
\text { (materiais ou não), significa a descoberta e a } \\
\text { construção de princípios a partir da } \\
\text { manipulação e do pensamento" (p.139). }\end{array}$ \\
\hline Da definição/formulação exata dos objetivos & $\begin{array}{c}\text { "Clareza na definição dos objetivos da } \\
\text { atividade para o satisfatório desenvolvimento } \\
\text { da atividade" (p.139). }\end{array}$ \\
\hline Do caráter seletivo da percepção & $\begin{array}{l}\text { "Nem tudo que chega ao aluno é refletido } \\
\text { automaticamente, há um atitude seletiva" (p. } \\
140) .\end{array}$ \\
\hline Do caráter ativo da assimilação & $\begin{array}{l}\text { "as riquezas culturais da humanidade devem } \\
\text { ser assimiladas no processo da atividade do } \\
\text { aluno com estas riquezas" (p.141). }\end{array}$ \\
\hline Da unidade entre o ilustrativo e verbal & $\begin{array}{l}\text { "as palavras adquirem o sentido que se atribui } \\
\text { aos objetos representados, possibilitando-se } \\
\text { evitar o verbalismo vazio de conteúdo" (p. } \\
\text { 144). }\end{array}$ \\
\hline Da retroalimentação & $\begin{array}{l}\text { "aprendizagem como um processo contínuo, } \\
\text { onde o aluno trabalha com apoio externo e } \\
\text { interação com colegas e professores" (p.144). }\end{array}$ \\
\hline
\end{tabular}

Quadro 4. Princípios didáticos derivados da Teoria Histórico-Cultural, Teoria da Atividade e Teoria da Assimilação

Acreditamos que estes princípios podem também ser utilizados para a análise de nossa Atividade, além de nos fornecer subsídios para a discussão dos resultados obtidos. 
Segundo Nunez (2009):

Esses princípios, junto com as teorias de aprendizagem, permitem uma análise científica dos processos e resultados obtidos, validando os conhecimentos psicopedagógicos estabelecidos, ajudando o seu aperfeiçoamento ou o estabelecimento de seus limites de validez ou, ainda, impulsionando a procura por novos referenciais teóricos (p. 129).

A seguir, discutiremos a relevância das necessidades para o desenvolvimento da humanidade e posteriormente, apresentaremos os fundamentos da Atividade Orientadora de Ensino (AOE), pautada na Teoria da Atividade de Leontiev.

\section{1 - Algumas considerações sobre o processo de objetivação/apropriação}

Desde os primórdios, o homem tem construído vários objetos com o intuito de satisfazer suas necessidades. Ao passo que as necessidades iniciais iam sendo supridas por meio de objetivações e apropriações em relação a estes objetos, novas necessidades eram estabelecidas - delineando assim todo o processo evolutivo. Por meio desta objetivação, a atividade material ou psíquica do homem transfere-se para o produto da referida atividade (MARX \& ENGELS, 1993).

A formação do ser humano pode ser evidenciada por estes dois processos acima destacados - a objetivação e a apropriação. A apropriação é continuamente mediada pela relação entre os seres humanos, sendo assim um processo educativo. A esse despeito, Duarte (2004), enfatiza que:

No caso específico da educação escolar, trata-se de um processo educativo direto e intencional (Saviani, 2003), por meio do qual o indivíduo é levado a se apropriar das formas mais desenvolvidas do saber objetivo produzido historicamente pelo gênero humano (DUARTE, 2004, p.51-52). 
Leontiev, assim como Vygotsky, vinculou a diferença entre homens e animais por meio da existência de processos de pensamento (consciência) e pela diferenciação entre as ações que cada um (ser humano e animal) realiza para satisfazer as suas necessidades. Ao longo dos anos, o homem construiu e continua construindo conhecimento em diversas áreas (como nas ciências naturais, humanas, etc) e a apropriação destes conceitos pelas gerações que se seguem é condicionada a meios específicos. Os instrumentos produzidos, físicos (objetos) ou simbólicos (linguagem), se tornam mediadores entre o homem e a natureza. Todavia, ao pensarmos nos animais, nos deparamos com a limitação de eles não serem munidos de linguagem verbal. Vale ressaltar que nós (seres humanos), pensamos em diversas possibilidades para os referidos animais e este é um importante fator que nos diferencia deles.

Os conceitos relativos a distintas áreas do saber são objetivações da atividade física e psíquica dos seres humanos, desenvolvidas na tentativa de se dominar os fenômenos que os circundam. Com o desenvolver da história, os instrumentos físicos e simbólicos tendem a evoluir para outros níveis de complexidade.

De acordo com Leontiev (1978b):

Para se apropriar dos objetos ou dos fenômenos que são o produto do desenvolvimento histórico, é necessário desenvolver em relação a eles uma atividade que reproduza, pela sua forma, os traços essenciais da atividade encarnada, acumulada no objeto (p. 268).

Assim, interpretamos que para se apropriar de um objeto (material ou não), determinado sujeito deverá relacionar-se com o mesmo por meio de uma atividade, que possa reportar a essencialidade (potencialmente histórica) reunida neste objeto.

Nem sempre, a referida atividade é caracterizada por meio de uma criação (produção) de um novo objeto. Por vezes, o sujeito estabelece sua própria atividade de utilização para um objeto pré-existente. Analisemos o exemplo a seguir:

Para fazer uso de uma caneta esferográfica comum, determinado indivíduo deverá estabelecer uma atividade de utilização, seja segurando a caneta entre os dedos polegar e indicador, seja entre o indicador e o médio, seja com os pés, seja como for. $\mathrm{O}$ 
fato é que para segurar a caneta, foi necessário reproduzir um formato inicial de utilização (historicamente acumulado).

Parafraseando Duarte (1992), no que tange a esfera do ensino e da aprendizagem, entendemos que esta reprodução é relativa a traços essenciais do processo histórico, sem obrigatoriamente ser necessário percorrer todas as etapas do mesmo. O importante é que o indivíduo se aproprie da lógica histórica de determinado produto ou objeto (p. 44).

No exemplo citado, a lógica poderia ser estabelecida por meio da possibilidade de se manipular a caneta, fazendo com que ela "funcione". Esta ação viria a suprir uma necessidade pontual, que poderia ser impulsionadora de novas necessidades.

No que diz respeito às necessidades dos indivíduos, Duarte (1992), afirma que:

(...) o homem não satisfaz suas necessidades primeiras de existência sem realizar a produção dos meios necessários a isso, o que se constitui em uma apropriação e uma objetivação; ao mesmo tempo esse "primeiro ato histórico" produz novas necessidades, que exigirão a produção de novos meios de satisfazêe-los, ou seja, exigirão nova apropriação e nova objetivação (p. 33).

E o autor continua enfatizando (como citado antes) que seria equivocado concluir que a relação "objetivação-apropriação" (e vice-versa) se estabeleça apenas quando o homem produz (cria) algo novo. Muitas vezes, descobrimos novas possibilidades, novas formas de uso para um objeto já existente. Todavia, nem sempre tais instrumentos são concretos. A linguagem e as relações desenvolvidas entre os homens também são passíveis de objetivação e apropriação. A concepção de possibilidades de comunicação também determina novas necessidades (DUARTE, 1992 p. 34-35).

A linguagem enquanto "evidência" dos processos psicológicos (pensamento) foi objeto de estudo de Vygotsky, Leontiev (entre outros) e foi referencial de análise em nossa pesquisa. No tópico 2.4 deste trabalho discutiremos as características dos processos psicológicos e sua relação com a fala. O processo de formação do indivíduo é considerado dinâmico e a interação entre os pares é fundamental para o seu desenvolvimento. 


\section{3 - A Teoria da Atividade e a Atividade Orientadora de Ensino}

\section{(AOE)}

Como mencionado anteriormente, o homem ao longo da história, tem produzido vários objetos com o intuito de suprir suas necessidades. Todavia, quando uma necessidade humana se materializa em um "objeto", temos o "motivo" para que uma atividade aconteça e podemos traçar objetivos para se obter e/ou se construir este objeto. "O objeto da atividade é seu motivo real" (LEONTIEV, 1983, p. 83). Esta atividade se desenvolverá por meio de "ações" e "operações", que determinado indivíduo executará de "forma motivada", para suprir sua necessidade inicial.

A situação a seguir foi utilizada com o intuito de evidenciar as condições estruturantes "ação" e "operação" de uma atividade:

Para "locomover um carro", determinado indivíduo, deve primeiramente adentrar o veículo, verificar se ele está desengrenado, para depois "virar" a chave e dar partida. Por fim, deve engrená-lo. Todas estas situações são consideradas ações previamente desenvolvidas que proporcionarão a operação de o carro "entrar em movimento", satisfazendo assim, uma necessidade primeira.

De acordo com Leontiev (1983):

A primeira condição de toda a atividade é uma necessidade. Todavia, em si, a necessidade não pode determinar a orientação concreta de uma atividade, pois é apenas no objeto da atividade que ela encontra sua determinação: deve, por assim dizer, encontrar-se nele. Uma vez que a necessidade encontra a sua determinação no objeto (se "objetiva" nele), o dito objeto torna-se motivo da atividade, aquilo que o estimula. (p. 107-108).

Assim, necessidade, objeto, motivo, ações e operações são condições estruturantes de uma atividade. Tal atividade funciona como um sistema que na prática não pode ser fragmentado. Seus elementos estruturantes laboram em conjunto e caracterizam um incessante movimento dialético.

A estrutura da Atividade proposta na figura 2 a seguir, foi adaptada a partir de Nunez (2009, p. 76). 


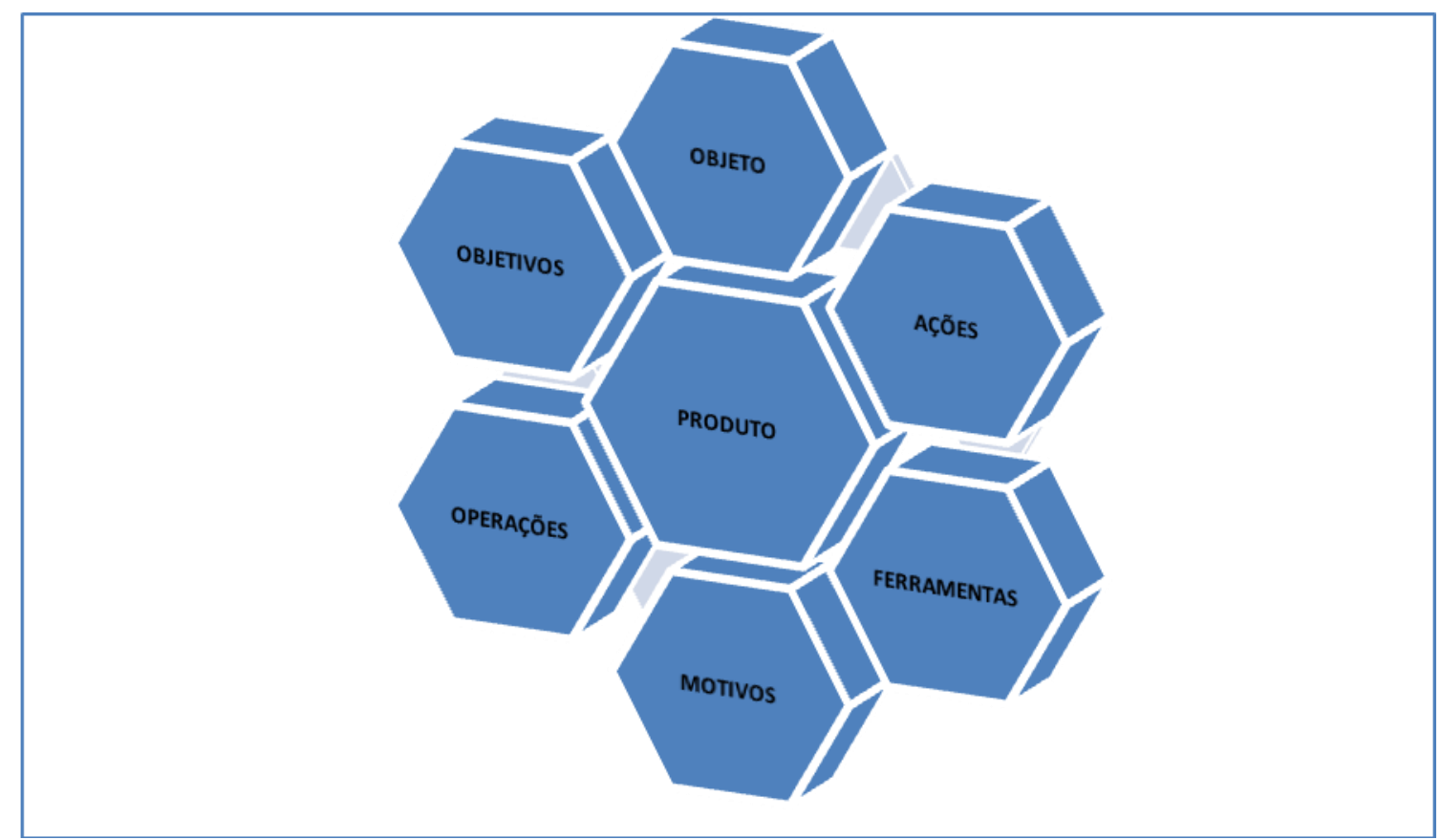

Figura 2: Estrutura da Atividade de Nunez (2009).

Nesta síntese estrutural da Atividade representada na figura 2, acreditamos que a "necessidade" foi suprimida pelo fato de se materializar no objeto, tornando-se assim o motivo da mesma (condição para o desenvolvimento de toda atividade psíquica).

Sobre as necessidades inerentes a cada atividade, Vygotsky (1985), afirma que:

Se ignorarmos as necessidades das crianças, aquilo que efetivamente as incentiva a agir, nunca seremos capazes de compreender seus avanços de um estágio evolutivo para o próximo, pois cada avanço está conectado com uma mudança significativa dos motivos, interesses e incentivos (p. 76).

A atividade pode ser sintetizada num sistema inter-relacionado, dialético e dinâmico, entre o sujeito (quem realiza a ação), objeto (para onde a ação é conduzida), motivo (vinculado à satisfação das necessidades), objetivo (resultados possíveis a serem obtidos), as próprias ações, operações (artifícios para desenvolver a ação), ferramentas, condições (situações) para realizar determinada ação e o produto da mesma (NUNEZ, 2009, p. 75).

Quando nos deparamos com as necessidades relativas ao ensino e aprendizagem arraigadas no sistema educacional, é imperativo propor situações para 
que os estudantes se apropriem dos conhecimentos historicamente acumulados, objetivando-os.

Neste ínterim, é que Moura (1992) propõe uma forma de organizar o ensino como atividade e cria então, a atividade orientadora de ensino (AOE). A necessidade de ensinar define o modo ou procedimento de como colocar os conhecimentos em movimento no espaço educativo e elege instrumentos auxiliares de ensino - adequados a cada objetivo e ação (livro, giz, calculadora, computador, etc). Por fim, os processos de análise e síntese, ao longo da atividade, são momentos de avaliação permanente para quem ensina e aprende (MOURA, 2001, p. 155).

$\mathrm{Na}$ AOE como unidade educacional, professor e aluno possuem a necessidade de ensinar e aprender, respectivamente. Para que esta se efetive, ambos os sujeitos deverão "entrar em atividade". O professor em atividade reestrutura seus conhecimentos por meios de ações e operações organizadas para a atividade, o que caracteriza AOE como unidade de formação de professor e aluno (MOURA, 1996, 2001). O aluno em atividade reestrutura seus conhecimentos por meio de ações e operações, com o objetivo de adquirir o conhecimento novo.

O objeto de ensino do professor deve ser concebido pelos alunos como objeto de aprendizagem e para tanto, tal objeto deve ser caracterizado como uma necessidade para ambos (natureza objetal). Ver figura 3.

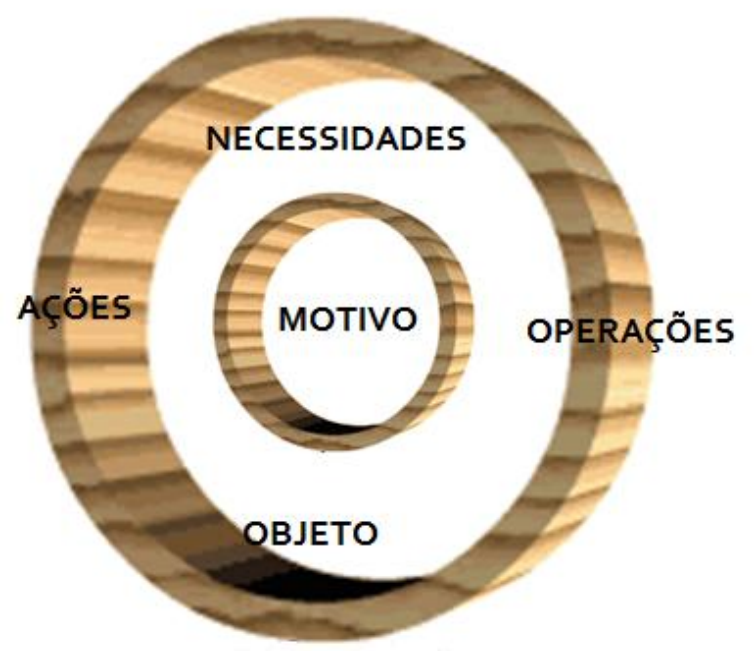

Figura 3: Estrutura da AOE - adaptação de Espimpolo (2013) 
A AOE mantém a estrutura da atividade proposta por Leontiev (1983), ao indicar uma necessidade (apropriação da cultura), um motivo real (apropriação do conhecimento historicamente acumulado), objetivos (ensinar e aprender) e propor ações que considerem as condições objetivas da instituição escolar (MOURA, 2010, p. 96).

Para despertar nos alunos a necessidade de apropriação de conceitos, situações desencadeadoras de aprendizagens podem ser estruturadas. Nestas situações, são apresentadas problemáticas a serem discutidas (refletidas) pelos alunos, com o intuito de possibilitar mobilizações (físicas e psíquicas) por meio de ações e operações.

Segundo Moura (2010), a situação desencadeadora de aprendizagem deverá considerar a origem do conceito, ou seja, quais necessidades, motivos, objetivos levou a humanidade a cria-lo. Para tanto, o referido autor recorreu ao termo história virtual do conceito, para que o aluno possa experimentar/simular a situação desencadeadora que em algum momento da história levou a sociedade a se apropriar de determinado saber.

\section{(...) o significado de virtual é encontrado ao se apresentar um problema na situação desencadeadora de aprendizagem que possua todas as condições essenciais do conceito vivenciado historicamente pela humanidade (MOURA, 2010, p. 105).}

Nesta pesquisa a AOE foi usada como recurso metodológico no ensino dos conceitos da disciplina QAQ. Todavia, a metodologia de pesquisa adotada foi a pesquisa participante.

Planejamos uma atividade por meio de um conceito sócio histórico (mais especificamente metal pesado) que foi desenvolvida na disciplina sob um olhar de pesquisa. Para a construção de um conceito, faz-se necessário o desenvolvimento de representações que forneçam relações do objeto de aprendizagem com o meio que o cerca.

De acordo com Vygotsky (1996), o conceito pode ser entendido da seguinte forma: 
É o reflexo objetivo das coisas em seus aspectos essenciais e diversos; se forma como resultado da elaboração racional das representações, como resultado de ter descoberto os nexos e as relações desse objeto com outros, incluindo em si, portanto, um amplo processo de pensamento e conhecimento que, dir-se-ia, está concentrado nele (p. 81).

Como exposto anteriormente, em nossa $\mathrm{AOE}$, um conceito científico (metais pesados) foi utilizado como referência, cuja designação é diferenciada em relação aos conceitos denominados como espontâneos (VYGOTSKY, 1989, p. 79). A seguir, faremos uma discussão a cerca destes conceitos escolares (ou científicos) e como eles poderiam ser estabelecidos (formados).

\section{4 - Os conceitos e os processos psicológicos}

Vygotsky (1989) abordou em seus estudos definições distintas para o que chamou de conceitos científicos e não científico, pautado em seus respectivos processos de formação. Os conceitos denominados como científicos (ou escolares), podem ser representados pelo conjunto de fenômenos desenvolvidos por meio da ciência e articulados por alguma teoria científica. Assim, são caracterizados pela inter-relação consciente entre a abstração e a generalização. Neste, as instituições escolares desempenham papel fundamental (NUNEZ, 2009). "A gênese deste conceito se inicia não com o choque direto com as coisas, mas na relação mediatizada com o objeto" (DAVIDOV, 1983, p. 221).

Já os conceitos não científicos (ou espontâneos) são obtidos em situações comuns do dia a dia, por meio de situações isoladas que envolvam tentativas e erros, sem maiores percepções conscientes das relações que poderiam ser estabelecidas. A diferenciação entre estes conceitos torna-se evidenciada pelo uso da palavra que pode desempenhar o papel de apenas conciliar determinados objetos (conceito espontâneo) ou proporcionar novos significados e processos de desenvolvimento mentais (conceito científico passível de generalização). 
Segundo Vygotsky (1989)

Os conceitos científicos se desenvolvem para baixo, por meio dos conceitos espontâneos, os conceitos espontâneos se desenvolvem para cima por meio dos conceitos científicos (p. 95).

Assim, percebemos que o "sentido" do caminho a ser percorrido pelos conceitos científicos se dá de cima para baixo (do abstrato para o concreto), ao passo que os conceitos espontâneos, evoluem de baixo para cima (do concreto para o abstrato). Faz-se necessário destacar que esta relação entre conceito científico e espontâneo não é linear e sim dialética, fato que denota toda a complexidade inerente ao termo (NUNEZ, 2009, p. 48).

O exemplo a seguir, foi elaborado com o intuito de retratar um possível momento deste percurso conceitual nas ciências naturais: Uma criança ou jovem começa a desenvolver conhecimentos espontâneos, pautados em conversas informais e de forma empírica. Assim, sempre ouvimos dizer que o famoso "galinho do tempo", muda de coloração (de azul para rosa), quando há previsão de chuva. Este conhecimento pode ser considerado de natureza espontânea, seja pelo fato de se ter ouvido adultos relatando o fenômeno, seja pela própria experimentação sensorial da criança.

Todavia, este conceito, poderá evoluir para "científico" (de baixo para cima), se em um âmbito escolar a criança desenvolver uma linguagem científica, apropriandose de símbolos e generalizações teóricas, aos casos específicos. Uma vez que o conhecimento científico é estabelecido, torna-se possível o percurso inverso (de cima baixo).

No caso do exemplo citado, se a criança ou jovem detém o conhecimento científico (geral e abstrato), ou seja, está ciente que alguns sais podem ser mais ou menos hidratados, de acordo com sua natureza e com o meio que estão inseridos, poderia percorrer o caminho conceitual inverso (do teórico ao caso particular concreto de cima para baixo) e inferir uma possibilidade de explicação. O referido "galinho" é revestido por um sal de cobalto II, que é azul na forma anidra (sem água) e apresenta coloração rosa, quando hidratado (tempo úmido).

Ao interpretar Vygotsky, entendemos que para o ser humano efetuar estas operações de pensamento, denominada "de cima para baixo" e vice-versa, seria 
necessário o desenvolvimento de funções psicológicas mais elaboradas, denominadas como "superiores".

De acordo com o referido autor, o ser humano seria dotado de "processos psicológicos inferiores" que estão vinculados a fatores biológicos, sendo estes basicamente similares a todas as raças em culturas e épocas. Há ainda o que o mesmo denominou como "processos psicológicos superiores", potencialmente evidenciados em pensamentos, operações reflexivas para a produção de instrumentos e consequente desenvolvimento sócio histórico. Esse desenvolvimento se torna possível, por meio das interações (mediações) estabelecidas entre os sujeitos “inseridos nestes processos".

No trecho a seguir, extraído de Leontiev (1989a), o autor faz uma consideração acerca dos processos ou funções psicológicas superiores, no que tange a importância conferida a mediatização (comunicação) entre estes sujeitos:

\begin{abstract}
Os processos psíquicos humanos - suas funções psicológicas superiores - se configuram numa estrutura que tem como qualidade de elo obrigatório os meios e métodos transmitidos de geração em geração no acontecer histórico e social da humanidade, durante o processo de colaboração $e$ de comunicação humana (p. 277).
\end{abstract}

Assim, sintetizamos que os "meios" (materiais ou não) são essenciais para o estabelecimento e transmissão da cultura, sempre mediados pelo homem. Um objeto é capaz de trazer consigo toda uma experiência acumulada historicamente, que pode vir a ser reestabelecida quando uma criança, por exemplo, entra em contato com o mesmo pela primeira vez. Este contato pode ser proporcionado pelos pais da criança, pelos amigos, pelos professores, acidentalmente em situações diversas, e etc.

Tomemos como exemplo, uma criança que pela impossibilidade de ser amamentada pela mãe, tomou leite em uma mamadeira comum desde os primeiros anos de vida. Em torno dos três anos da criança, os pais decidiram "apresentar" e sugerir à criança o uso do copo. A palavra apresentar foi grafado entre aspas, uma vez que de certa forma, não seria a primeira vez que a criança estaria visualizando determinado objeto. Todavia, poderia ser o primeiro momento em que a criança estivesse de frente à possibilidade de refletir acerca do uso deste copo, de forma objetal. Relatamos que este processo poderia se desenvolver de forma diferenciada em relação ao irmão da mesma 
criança ou qualquer outra criança próxima. Assim, faz-se necessário ressaltar que a possibilidade de significação ou ressignificação se daria de forma específica e particular para cada ser humano que se apropria do mesmo (apesar da necessidade de mediação).

De outra forma, poderíamos cogitar a possibilidade de se inserir o mesmo objeto comentado acima ("impregnado" de cultura) a uma matilha de lobos isolados em uma floresta qualquer. Qual seria ou existiria alguma possibilidade de apropriação? Ou seria possível apenas determinada adaptação?

E se este mesmo copo fosse enviado para um ser humano (hipotético) que viveu sozinho toda a sua vida e nunca teve contato algum com qualquer outra raça? Seria provável algum grau de assimilação ou apropriação?

A abordagem acima tem o objetivo nos instigar a reflexão acerca dos limites fisiológicos, bem como das possibilidades sociais e psicológicas de cada ser. Tal raciocínio em torno das limitações relativas às influências biológicas para o desenvolvimento da humanidade foi também evidenciada por Leontiev (1978), que afirmou que:

O homem não está evidentemente subtraído ao campo da ação das leis biológicas. O que é verdade é que as modificações biológicas hereditárias não determinam o desenvolvimento sócio histórico do homem e da humanidade (p. 264).

Seguindo esta linha de discussão, poderíamos inferir que de forma geral, o homem possui a mesma estrutura fisiológica e que o seu desenvolvimento psíquico estaria vinculado ao convívio social que foi constituindo a história da humanidade.

Leontiev (1978b) discute a relação entre a base biológica (hereditária) e a herança sócia histórica, da seguinte forma:

(...) por um lado, os fatos indicam que as aptidões $e$ as funções que se desenvolvem no curso da história social da humanidade não se fixam no cérebro do homem e não se transmitem segundo as leis da hereditariedade. Por outro lado, é absolutamente evidente que uma aptidão ou uma função não pode ser senão a função de um órgão ou de um conjunto de órgãos determinados...(p. 271). 
Partindo do pressuposto que todo ser humano é similar fisiologicamente, retomemos aos exemplos acerca do copo "enviado" para uma matilha de lobos e para um homem "primitivo" desprovido de interação social. O próximo questionamento latente gira em torno da comparação deste homem "isolado" com os demais que vivem em sociedade, bem como a comparação deste homem com os outros animais. Qual seria a diferença? Existe alguma semelhança?

Cabe aqui, uma reflexão acerca do importante instrumento técnico da voz de que o homem socialmente desenvolvido é munido e que o diferencia significativamente de outros animais. O homem desenvolve vários instrumentos ao longo de sua vida com o intuito de aperfeiçoá-la em qualidades e transmite estes ensinamentos por meio do trabalho e linguagem.

Já os animais, produzem instrumentos e os utilizam para satisfação momentânea, sem aplicações no campo do trabalho, fato que os limitou em relação ao desenvolvimento oral e consequente cultura a ser transmitida. Enquanto os animais atuam para satisfazer suas necessidades, os homens agem para produzir elementos de satisfação de suas necessidades (MARX \& ENGELS, 1993, p. 39-40).

Assim sendo, os sistemas de fala e a consequente escrita poderiam ser considerados como sistemas de signos utilizados com duas funções: além de preservar o potencial histórico acumulado, seriam também semelhantes a instrumentos a serem utilizados para o ascendente domínio do comportamento humano (VYGOTSKY e LURIA, 1930a, p. 54).

Para Vygotsky (1989),

Todas as funções psíquicas superiores são processos mediados e os signos constituem o meio básico para dominá-los e dirigi-los. $O$ signo mediador é incorporado na sua estrutura como uma parte indispensável, na verdade, a parte central do processo como um todo. Na formação do conceito, esse signo é a palavra, que em princípio tem o papel de meio na formação de um conceito $e$ posteriormente, torna-se seu símbolo (p.88).

Nesse ínterim, acreditamos que a mediatização e o sistema de signo evidenciado por meio da palavra, representam um importante papel em nossa 
“investigação sobre uma nova alternativa metodológica”, uma vez que possuímos um objeto de pesquisa situado no campo abstrato.

\section{5 - A AOE e nossa proposta em QAQ}

Como mencionado anteriormente, a AOE foi proposta por Moura (1992) pautada no conceito da Teoria Psicológica Geral da Atividade (LEONTIEV, 1983), também denominada Teoria da Atividade. Esta teoria foi embasada pela perspectiva histórico-cultural, uma vez que define a necessidade como o ponto de partida para um sujeito iniciar uma atividade. No caso específico da AOE, situações desencadeadoras de aprendizagem são utilizadas para proporcionar ao aluno, uma possibilidade sócio histórica de interação com o conceito a ser apreendido.

$\mathrm{Na}$ atividade proposta em nosso trabalho, tivemos como objeto uma situação particular (desencadeadora de aprendizagem) que foi desenvolvida com o intuito de proporcionar (mediatizar) a essência comum em todas as etapas do processo da marcha analítica de QAQ.

Esta evolução do concreto ao abstrato foi defendida por Vygotsky como generalização empírica (NUNEZ, 2009, p. 183). No formato trivial de Ensino, geralmente partimos do abstrato (marcha analítica no caso da QAQ - conceito científico) e caminhamos para o concreto, desenvolvendo assim algumas amostras para serem aplicadas como exemplos pontuais.

A figura 4 abaixo sintetiza e compara nossa proposição, fundamentada nas ideias de Vygotsky (situação 1) em detrimento do ensino tradicional (situação 2). 


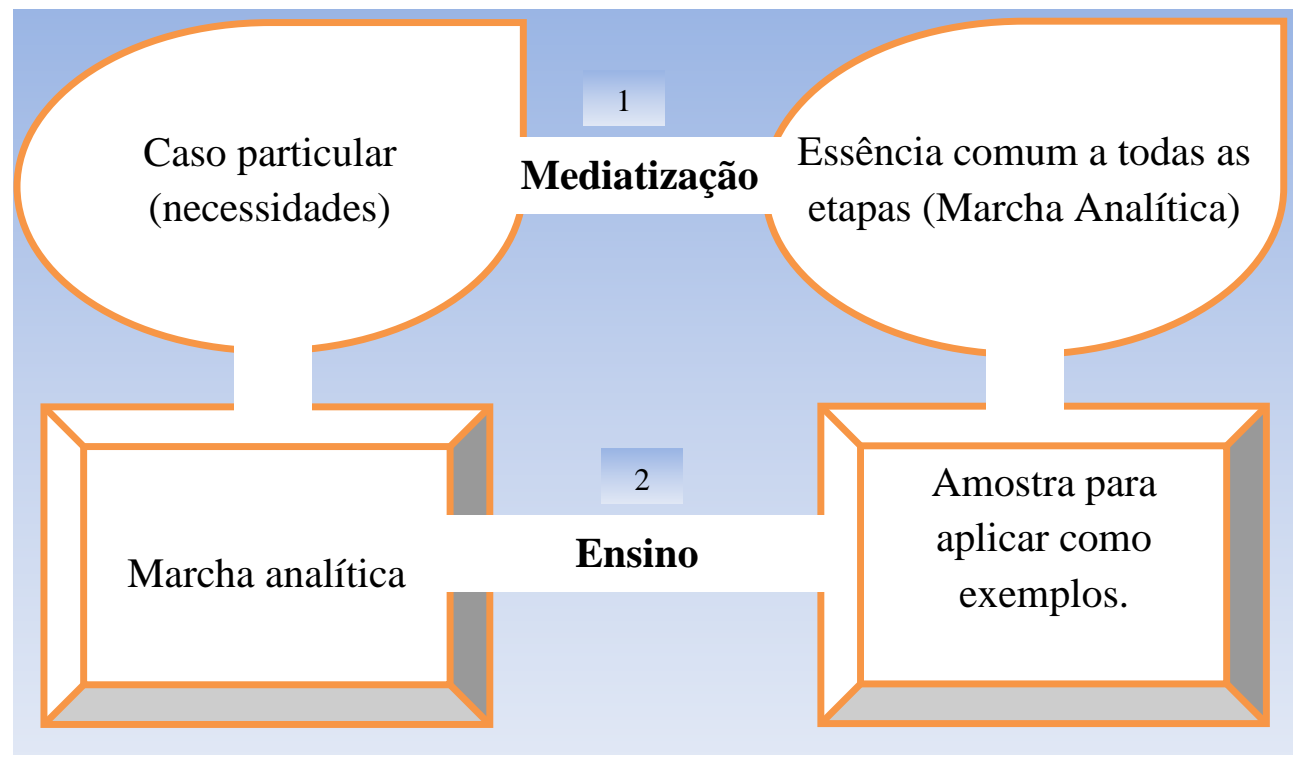

Figura 4: Mediatização e o Ensino Tradicional em QAQ

Na primeira situação, demonstramos a possibilidade de se partir de um caso específico que ao ser mediatizado, poderia evoluir para determinada generalização e estabelecimento do pensamento teórico. Todavia, na segunda situação, evidenciamos que o ensino específico de QAQ, ao ser iniciado por meio da marcha analítica "geral", poderia favorecer a aplicação pontual em contextos específicos (concretos), se tornando assim dependente do contexto.

O que precisamos deixar relatado, é que as referidas situações delineadas na figura 4, não são lineares e experimentam um movimento dialético. Por isso, as quatro situações descritas estão inter-relacionadas por meio de uma "ponte" que não denota flechas, nem sentidos. O esquema foi produzido com o intuito de auxiliar a compreensão de um processo complexo, proposto por Vygotsky (1989) no que diz respeito aos conceitos científicos e espontâneos, ambos pautados nesta "movimentação".

Ao se deparar com a possibilidade de a AOE ser utilizada como recurso metodológico, algumas questões podem se tornar latentes:

Mas no que a AOE avança? Qual a sua diferença em relação a outras propostas como, por exemplo, a de "aprendizagem por problematização"?

No meio escolar, diversas atividades podem ser desenvolvidas por meio de "questões problematizadoras", no qual situações são contextualizadas e se torna 
responsabilidade do aluno a busca por determinada resolução. Todavia, nem sempre, atividades como estas podem ser consideradas "orientadoras".

Segundo Nunez (2009),

No que se refere ao processo de ensino $e$ de aprendizagem em sala de aula, o aluno pode realizar muitas atividades, sem ter clara consciência de suas ações. Podem ser processos de adaptação e de regulação de sua atividade pelos objetos. Não obstante, requer da consciência quando precisa regular a ação (p. 67).

Para Leontiev (1989),

A atividade é uma unidade molar não aditiva da vida do sujeito corporal e material. Num sentido mais estreito, ou seja, ao nível psicológico, esta unidade é mediada pelo reflexo psíquico, cuja função real consiste em que este orienta o sujeito no mundo dos objetos. Em outras palavras, a atividade não é uma reação, e sim um sistema que possui uma estrutura, passos internos, um desenvolvimento (p.266).

Fundamentados nos dois autores acima, entendemos que atividade "comum" é habitualmente desenvolvida por meio de processos de adaptação ao objeto, como uma espécie de "reação imediata" ao problema proposto e cuja "resolução" poderia ser aplicada a determinados contextos sem maiores articulações psíquicas.

Ao retomar a proposta de Atividade proposta por Leontiev, podemos ainda inferir que a "verdadeira atividade" pode ser caracterizada pela coincidência entre seu objetivo e motivo. Se esta coincidência não for estabelecida, teríamos apenas algumas ações a serem desenvolvidas e não a atividade propriamente dita.

Entretanto, a atividade mais elaborada, pode ser mediatizada por reflexões psíquicas que favorecem a orientação do sujeito aos objetos, de forma a proporcionar paulatinas mudanças psicológicas. Nesta, não é objetivo transformar o referido objeto e sim refletir acerca dele.

Assim, voltamos a destacar que em nossa pesquisa sobre a potencialidade da AOE como recurso metodológico para a disciplina de QAQ, as reflexões 
proporcionadas pelo conhecimento químico a ser posto em movimento, poderiam nos auxiliar na ponderação desta metodologia.

\section{METODOLOGIA DE ENSINO}

No caso particular da disciplina de QAQ, uma notícia atual acerca da existência de metais pesados encontrados em alguns cosméticos, como batons e brilho labiais nos EUA, foi referência para elaboração de duas situações desencadeadoras de aprendizagem. O resumo da notícia está apresentado no Quadro 5 abaixo:

\section{"Estudo dos EUA alerta para índices de metais em batons e brilhos}

labiais” - Pesquisa encontrou chumbo, cádmio e cromo em cosméticos analisados. Alguns componentes químicos estão relacionados a doenças como câncer.

* Disponível em:

<http://g1.globo.com/bemestar/noticia/2013/05/estudo-dos-eua-alerta-para-indices-demetais-em-batons-e-brilhos-labiais.html> (nacional).

<http://ehp.niehs.nih.gov/wp-content/uploads/121/6/ehp.121-a196.pdf> (original em

inglês).

Quadro 5. Resumo da notícia utilizada como referência para AOE

Os metais encontrados nestes cosméticos dos EUA foram importantes porque puderam ser utilizados como representantes dos cátions dos grupos V, IV e III de QAQ, supracitados no Quadro 2. Assim, AOE proposta apresenta o conteúdo central sobre metais considerados pesados (grupos analíticos IV e V) e metais do grupo III (Crômio e Alumínio).

O fato de também estar presentes metais do grupo III foi importante porque favoreceu uma análise conjunta com os grupos analíticos IV e V. Este fato possibilitou a abordagem completa dos cinco grupos analíticos na disciplina QAQ, de acordo com a classificação proposta por Fresenius (1879). Vale ressaltar que na AOE proposta por Espimpolo (2013), apenas os grupos III, II e I foram desenvolvidos.

Assim, na AOE desenvolvida no atual trabalho, duas situações desencadeadoras de aprendizagem foram propostas. A primeira situação 
desencadeadora foi apresentada com o objetivo de abordar o conceito sócio histórico acerca de metais pesados, sua presença na natureza, bem como a reflexão de sua importância. A abordagem propiciada pela segunda situação apresentou a relevância em torno da separação e identificação destes metais ao longo da história e na contemporaneidade. De certa forma, em ambas as situações desencadeadoras o aluno foi levado à reprodução das necessidades sócio históricas, no que tange o envolvimento entre o homem, os metais pesados, o meio ambiente e a consequente necessidade de separação e identificação destes metais.

O tema desta AOE é referente aos conteúdos de dois grupos específicos de metais abordados na QAQ que deverá ser traduzido em conceitos a serem apropriados pelos estudantes. Acredita-se que a $\mathrm{AOE}$ enquanto ferramenta metodológica pode auxiliar o estudante na promoção da aprendizagem.

Os encontros realizados foram vídeo gravados, transcritos e posteriormente analisados, a partir do método dialético (Kosik, 1926). Partimos do pressuposto de que indícios da aprendizagem poderiam revelar o potencial da atividade. A fundamentação teórica apoiou-se na perspectiva histórico cultural (Vigotsky, 1989) e na teoria da atividade (Leontiev, 1983).

Os sujeitos desta pesquisa são alunos de um curso de Licenciatura em Química, regularmente matriculados na disciplina de Química Analítica Qualitativa, que é oferecida no terceiro semestre do mesmo. A turma foi composta por 23 alunos.

A AOE foi subdivida em três encontros previamente acordados e inseridos no cronograma da disciplina. Os dois primeiros encontros foram desenvolvidos em sala de aula, em duas aulas simples de 1h40, para a discussão teórica acerca do tema central - metais pesados - e consequente método de identificação e separação dos mesmos.

Com duas semanas de antecedência em relação ao primeiro encontro teórico, os alunos receberam dos pesquisadores a notícia referente aos metais pesados em cosméticos nos EUA, bem como o texto referente à AOE proposta (em anexo). O objetivo neste primeiro momento foi que os alunos realizassem uma busca referente ao assunto para fundamentar a discussão inicial.

No primeiro encontro, os alunos foram divididos em cinco grupos de três alunos e dois grupos com quatro alunos. Na primeira situação desencadeadora de aprendizagem (situação 1), proposta na $\mathrm{AOE}$, os alunos foram convidados a se portarem 
como um químico contratado pela "empresa que investiga o fato descrito na reportagem”. Como tal, deveriam conceder uma entrevista para uma empresa televisiva explicando para população, do ponto de vista científico, qual é o problema com relação aos metais pesados, no que diz respeito à saúde pública e ao meio ambiente.

Algumas questões orientadoras foram anotadas na lousa (Quadro 6 abaixo). Os grupos tiveram vinte minutos para debater entre eles as questões pré-estabelecidas.

Qual é o problema de se ter metal pesado (MP) nos batons?

Que risco o consumo destes produtos cosméticos pode trazer para as mulheres? E homens?

Podemos descartar os MP na natureza? Que consequências isso pode trazer para o meio ambiente? Ingestão de qualquer concentração destes metais é prejudicial? Dê exemplos.

Retomando o problema com o resíduo das amostras de batom, proponha uma rota para separar e identificar os possíveis metais.

Quadro 6. Questões orientadoras para o desenvolvimento da discussão

Após esta discussão em cada grupo, este elegeu um represente para expor as ideias do mesmo para serem debatidas com os demais integrantes dos outros grupos. Uma discussão acerca das definições sobre metal pesado e a sua consequente bioacumulação e biomagnificação no meio ambiente foi desenvolvida. Ao final deste encontro, os alunos entregaram para os pesquisadores textos reunindo as informações levantadas para resolver a situação-problema. A última questão do Quadro 6, referente à rota (marcha analítica) de separação dos metais pesados foi iniciada no final do primeiro encontro e retomada no segundo encontro teórico.

No segundo encontro, os mesmos grupos de alunos foi reestabelecido e o material teórico reunido no primeiro encontro foi devolvido aos mesmos. Uma segunda situação desencadeadora de aprendizagem (situação 2) foi proposta com o objetivo de despertar nos alunos a necessidade em se apropriar dos conceitos envolvidos na parte experimental da QAQ - separação e identificação. Nesta etapa, os alunos foram submetidos a uma situação fictícia na qual eles seriam os químicos responsáveis por decidir a destinação mais adequada para uma amostra dos cosméticos sob suspeita, 
deixada num laboratório em um béquer. Para esta tarefa, eles deveriam supor que tal solução poderia conter altas concentrações dos metais citados na notícia. Precisariam analisá-la e emitir um parecer sobre a composição, bem como propor uma rota para separar e identificar os possíveis metais nela existente.

Um aluno representante de um dos grupos iniciou a rota anotando na lousa os metais existentes na "amostra teórica" de batons. Posteriormente os representantes dos outros grupos também foram à frente explanar suas contribuições. Assim, os alunos mediados pelos professores/pesquisadores, construíram coletivamente uma rota de separação para ser utilizado no terceiro encontro que seria de caráter experimental.

Por fim, o terceiro encontro foi desenvolvido no laboratório didático experimental, em uma aula dupla de 3h30. Os alunos foram divididos em 11 duplas e um aluno desenvolveu a atividade experimental individualmente. Para esta parte, planejamos uma amostra real contendo sais dos metais (solução aquosa) citados na reportagem de cosméticos dos EUA (chumbo, cádmio, crômio e alumínio) eacrescentamos um metal extra (mercúrio I) ${ }^{2}$. Desta forma, os alunos tiveram um nível de dificuldade um pouco maior no que diz respeito à separação deste grupo, que foi precipitado na forma de cloretos (reagente do grupo V). Por meio do produto de solubilidade dos sais dos metais, equilíbrio químico em solução aquosa, solução tampão, variação de $\mathrm{pH}$, números de oxidação entre outras especificidades químicas ${ }^{3}$ e condições de reação, os alunos deveriam identificar cada metal separadamente.

Geralmente, nas aulas tradicionais de laboratório, os estudantes recebem um roteiro para ser seguido durante a realização do experimento. Com a atividade proposta, a rota a ser utilizada foi desenvolvida por toda a turma durante os encontros teóricos. Os

\footnotetext{
${ }^{2}$ Mercúrio I: O mercúrio I foi adicionado porque é típico do grupo V (lembrando que o mercúrio II pertence ao grupo IV). A prata não foi selecionada porque os estudantes já tiveram oportunidade de conhecer as suas reações na identificação do íon cloreto. Já o chumbo II, além de pertencer ao grupo V, pertence também ao grupo IV.
}

3 Produto de solubilidade (Kps): Constante de equilíbrio entre um sólido e seus íons dissolvidos; equilíbrio químico: Reações diretas e inversas ocorrem com a mesma velocidade; tampão: Solução em que o pH tende a permanecer constante após a adição de pequenas quantidades de ácidos ou bases; pH: Escala numérica obtida pelo valor negativo do logaritmo de base 10 da concentração de íons hidrogênio; oxidação:É a perda de elétrons, redução é o ganho de elétrons. A reação redox é a combinação de oxidação e redução.

Fonte: Atkins e Jones, Princípios de Química: questionando a vida moderna e o meio ambiente, $5^{\mathrm{a}}$ ed. 2012. 
volumes de reagentes e consequentes condições experimentais foram discutidos/debatidos pelos alunos. Vale ressaltar que os mesmos haviam realizado apenas a separação e identificação dos grupos I, II e III.

Todos os encontros foram vídeo gravados e transcritos. Para a preservação do sigilo, optamos por nomear os alunos envolvidos por letras e números (A/1, A/2, D/1, D/2 assim por diante). Denominei-me como Pesquisador P/1 e a professora responsável pela disciplina como Pesquisador $\mathrm{P} / 2$. Sempre que necessário, os alunos eram questionados pelos pesquisadores, cujo papel foi mediar à discussão e investigar a potencialidade da AOE como recurso didático. Por meio das discussões, foi possível investigar o potencial da AOE proposta. Assim, para a análise dos dados, nos pautamos na perspectiva histórico-cultural, a qual pressupõe que "o homem se faz ao produzir os seus objetos e que, ao produzir os seus objetos, ele produz também as suas significações, cuja expressão máxima é a palavra" (MOURA, 2004, p.260).

\section{METODOLOGIA DE PESQUISA}

Em nosso trabalho, optamos por utilizar como metodologia, a "pesquisa participante" (Brandão, 1984; Ezpeleta, 1986) e empregar como instrumental de análise, o método dialético (Kosik, 1926). Os encontros foram vídeos gravados, transcritos e posteriormente analisados a partir do método dialético.

A metodologia de ensino adotada propiciou a interação entre os alunos da disciplina e o professor/pesquisador. A pesquisa participante tem recebido diferentes nomes ao longo das últimas décadas. Dentre eles, podemos destacar a denominada "autodiagnostico", a "pesquisa ação", a "pesquisa participativa" ou ainda a “investigação ação participativa” (BRANDÃO, 2007, p. 53). Mais adiante, faremos também uma alusão à "observação participante", de acordo com o mesmo autor (BRANDÃO, 1984).

Todavia, a nossa participação como pesquisadores na disciplina de QAQ não se deu em uma forma direta, ao passo que não desenvolvemos (realizamos) as atividades teóricas e experimentais junto aos alunos. Esta prática nos tornaria também sujeitos “diretos" desta investigação. 
Para Brandão (2007),

A relação tradicional de sujeito-objeto, entre investigador-educador e os grupos populares deve ser progressivamente convertida em uma relação do tipo sujeito-sujeito, a partir do suposto de que todas as pessoas e todas as culturas são fontes originais de saber. É através do exercício de uma pesquisa e da interação entre os diferentes conhecimentos que uma forma partilhável de compreensão da realidade social pode ser construída (p. 54).

Como mencionado no tópico 3 (Metodologia de Ensino) deste trabalho, tivemos um objeto - a nossa AOE - que foi desenvolvida em três encontros. Acreditamos que os momentos de interação vivenciados, possibilitaram o incremento de uma relação do tipo sujeito-sujeito citada pelo autor. Entretanto, devemos enfatizar que esta nossa participação (enquanto sujeitos) adveio com determinadas especificidades. Nesta pesquisa, nós pesquisadores participamos enquanto mediadores do processo (atividade) proposto. Precisamos ainda, pontuar que a linguagem utilizada foi crucial para desencadear todo este "processo participativo mediatizado".

Para Ezpeleta (1986),

Segundo o peso relativo dos vários elementos que a constitui, a pesquisa participante assume formas diferentes (...). A primeira coisa que chama a atenção é a linguagem. Uma linguagem que pretende denominar a realidade de "outro" modo e que, assim, procura constituir-se ao mesmo tempo em linguagem crítica. Este "outro" modo é um modo diferente daquele que a ciência social dominante utiliza. Trata-se, em geral, de uma linguagem com claras ressonâncias marxistas ( $\mathrm{p}$. 77-78).

A linguagem é o ponto central em nossa pesquisa. Por meio dela, reflexões, abstrações, objetivações e apropriações poderiam se tornar comumente expressas - daí a relação com as ideias marxistas referidas pela autora.

Em uma referência ao texto de Brandão (1984), Ezpeleta (1986), evidencia que a "pesquisa participante" e a "observação participante" estão diretamente ligadas - "não se pode falar de uma sem se falar da outra" (p. 82). Assim, acreditamos também que a 
unidade dialética entre pesquisa e observação seja estabelecida. Seguindo esta linha de raciocínio, tanto a pesquisa, quanto a observação participante, seriam potencialmente importantes para a construção sócio histórica do conhecimento.

Esta constatação foi evidenciada da seguinte forma:

A propósito da observação participante, o texto (de Brandão, 1984), destaca o interesse por um problema particular; "a constituição do outro na relação que se estabelece na pesquisa”. No que diz respeito a isto, o texto sustenta que a observação participante possibilita formas de interação entre pesquisador e sujeitos, permitindo uma abordagem pessoal e abrindo fontes de informação que nenhuma outra técnica tornaria possível (EZPELETA, 1986, p.83).

Vale ressaltar que anteriormente, o mesmo autor (Brandão, 2007) - na p.52 deste trabalho - citou determinada mudança progressiva no que diz respeito à interação inicial entre sujeitos e pesquisadores, a ser transformada em uma relação entre sujeitos (no que tange as fontes do saber).

Em nossa atividade os estudantes foram inicialmente subdivididos em grupos, os quais discutiram internamente cada situação proposta e que posteriormente, socializaram as suas ideias com os demais grupos e pesquisadores. Ou seja, as interações começaram pela comunicação sujeito-sujeito (em grupos internos de alunos) e evoluiu para a socialização sujeito-sujeito (entre outros grupos), além da já citada interação sujeito-pesquisador. Ao atingir este patamar de discussão, poderíamos inferir que todos (aluno, grupos de alunos, pesquisadores) se configuraram enquanto sujeitos.

Ao refletir acerca da metodologia - pesquisa participante - a autora Ezpeleta retoma os questionamentos de Brandão (1984), acerca do "que seria participar" e "quem” participaria “do que”? (EZPELETA, 1986, p.82). Ela afirma que este "do que", seria traduzido pelos fenômenos (processos) sociais vivenciados pelos sujeitos.

Com relação ao "quem", a autora relata que: 
O próprio debate da pesquisa participante indica que esse quem da pergunta é um sujeito. Uma pessoa com a qual interajo; que me ensina as coisas; descobre-me seus mundos e outras visões dos meus e, além disso, enriquece-me. Um alguém concreto, com o qual devo relacionar-me numa tarefa comum e que, por isso mesmo, me modifica de algum modo (p. 90).

Em nossa pesquisa, para discutir acerca do que se configuraria como participação e quem participaram de qual atividade, poderíamos retomar o exemplo da AOE desenvolvida (p. 47 - metodologia de ensino deste trabalho). Nesta, os alunos do curso de Licenciatura em Química e os pesquisadores em questão se caracterizaram enquanto sujeitos participantes. Confiamos que a interação entre estes pares permitiu importantes abordagens de ensino e aprendizagem, no que configura uma explanação conceitual - não apenas limitada a um caso isolado.

Para Brandão (2007),

Na pesquisa participante sempre importa conhecer para formar pessoas populares motivadas a transformar os cenários sociais de suas próprias vidas e destinos $\boldsymbol{e}$ não apenas para resolverem problemas locais restritos e isolados, ainda que o propósito mais imediato da ação social associada à pesquisa participante seja local e específico (p.56).

Este movimento (interação) entre os sujeitos foi proporcionado por meio do desenvolvimento de uma tarefa comum (local) a todos eles - a AOE. Neste movimento, acreditamos que aluno e professor se formam juntos e ambos possuem motivos pessoais e coletivos.

O materialismo histórico dialético utilizado com o intuito de se apreender o "sentido das coisas" nos pareceu adequado para dar suporte ao entendimento do nosso objeto de estudo, ao passo que a pesquisa participante possui raízes marxistas. Este fenômeno deve ser analisado em movimento, pois os sujeitos envolvidos modificam suas qualidades/características a cada compartilhamento de significados que é experimentado em suas ações educativas (MOURA, 2004). 
Para Kosik (1976),

Captar o fenômeno de determinada coisa significa indagar e descrever como a coisa em si se manifesta naquele fenômeno, e como ao mesmo tempo nele se esconde. Compreender um fenômeno é atingir a sua essência. Sem o fenômeno, sem a sua manifestação e revelação, a essência seria inatingível. (...) O fenômeno não é, portanto, outra coisa senão aquilo que - diferentemente da essência oculta - se manifesta imediatamente, primeiro e com maior frequência (p. 12).

Assim, entendemos que na tentativa de se estudar determinada essência, temos um acesso mais imediato ao fenômeno (e não a coisa em si). Neste e em outros momentos de estudos, geralmente temos o contato inicial com o fenômeno em si, que pode nos auxiliar na compreensão da essência. Em síntese, determinado fenômeno que estudamos pode ser analisado com o intuito de se compreender a essência do mesmo.

E continua mais adiante:

Como a essência - ao contrário dos fenômenos não se manifesta diretamente, e desde que o fundamento oculto das coisas deve ser descoberto mediante uma atividade peculiar, tem de existir a ciência e a filosofia. (...) A filosofia é uma atividade humana indispensável, visto que a essência da coisa, a estrutura da realidade, a "coisa em si", o ser da coisa, não se manifesta direta e imediatamente (KOSIK, 1976, p.13-14).

Acreditamos que as ciências de forma geral, possuem este papel de nos auxiliar na "compreensão das coisas em si”. As atividades desenvolvidas ao longo de nossa história nos permite vivenciar os fenômenos e indiretamente a essência de cada coisa (conceitos).

Por isso, optamos em utilizar a dialética como instrumental de análise de nossa atividade. Investigamos a $\mathrm{AOE}$ enquanto recurso metodológico em uma disciplina tradicional de um curso Superior, onde o processo de ensino e aprendizagem (que é dinâmico) poderia ser estabelecido (conhecimento construído). O movimento dialético corrobora com o fato de a realidade não se concentrar no aparente, no que é 
superficialmente desvendado pelos sentidos. Neste movimento, tudo está configurado de forma interdependente e relativa.

A dialética não atinge o pensamento de fora para dentro, nem de imediato, nem tampouco constitui uma de suas qualidades; o conhecimento é que é a própria dialética em uma de suas formas; o conhecimento é a decomposição do todo. $O$ "conceito" e a "abstração", em uma concepção dialética, tem o significado de método que decompõe o todo para poder reproduzir espiritualmente a estrutura da coisa, e, portanto, compreender a coisa (KOSIK, 1976, p.14).

$\mathrm{Na}$ AOE desenvolvida em nosso trabalho, o conceito relativo aos metais pesados, bem como as possibilidades de identificação e separação dos mesmos foram importantes para proporcionar aos alunos a experiência com o fenômeno, que mesmo "fragmentado", poderia possibilitar a explanação para o todo - no que diz respeito à estrutura, a compreensão e a essência do conceito.

Ao discutir a dialética entre o que se poderia ser considerado "decomposição" e "totalidade" do conhecimento, Kosik (1976), afirma que "sem decomposição não há conhecimento" (p.14). O ser humano, de forma geral é específico a determinadas ações, e quando se concentra em suas abstrações, corre o risco de menos valorizar outros momentos da realidade. Todavia,

O impulso espontâneo da práxis e do pensamento para isolar fenômenos, para cindir a realidade no que é essencial e no que é secundário, vem sempre acompanhado de uma igualmente percepção do todo, na qual e da qual são isolados alguns aspectos... (KOSIK, 1976, p.15).

Desta forma, podemos inferir que independentemente do conceito estudado ser considerado essencial ou secundário (uma vez que isto também é relativo e dialético), torna-se importante desenvolver a configuração e a percepção do todo. No que diz respeito a nossa proposta metodológica (passível de movimentação), este tipo de percepção "mais ampla”, poderia nos fornecer indícios de potencialidade. 
A dialética não considera os produtos fixados, as configurações e os objetos, todo o conjunto do mundo material reificado, como algo originário e independente. Do mesmo modo como assim não considera o mundo das representações e do pensamento comum, não os aceita sob o seu aspecto imediato: submete-os a um exame em que as formas reificadas do mundo objetivo e ideal se diluem, perdem a sua fixidez... (KOSIK, 1976, p.16-17).

Assim, a pesquisa participante e a dialética corroboraram para o desenvolvimento metodológico de nossa pesquisa, uma vez que se tratou de um trabalho de Ensino, que como tal pode ser considerado dinâmico e interativo. Na natureza, nas ciências, na vida, coisa alguma está fixada.

\section{RESULTADOS E DISCUSSÃO}

Os princípios e concepções sobre o ensino determinam e definem os métodos, recursos e forma de organizar o ensino. Toda atividade didática é intencional. A organização do ensino-aprendizagem tendo por base pressupostos teóricos a perspectiva histórico-cultural de Vigotsky, a teoria da Atividade de Leontiev e estudos sobre assimilação de Galperin reúne uma série de princípios que refletem a aplicação destas teorias no contexto da prática pedagógica (Nunez, 2009). Assim, ao considerar a organização da AOE pode-se afirmar que esta reúne os seguintes princípios:

a) Proporciona uma formação mais ampla do aluno, contemplando aspectos cognitivos e afetivos, uma vez que o tema escolhido "cosméticos" é de interesse dos estudantes na faixa etária em que se encontram.

b) Procura instrumentalizar o aluno para que interaja com a realidade. $\mathrm{O}$ conhecimento proporcionado pela atividade possibilita que ele tenha mais elementos pra consumir um produto de forma consciente e responsável;

c) Exige a seleção conhecimentos, valores, ética que não satisfazem somente uma condição empírico-utilitária, mas projete um pensamento que permita ao aluno ter uma ação criativa diante da realidade. A atividade permite a discussão de aspectos éticos do profissional da área da química;

d) Incentiva que a apropriação dos conteúdos se dê de maneira consciente. 
A palavra é instrumento fundamental da interiorização, segundo Galperin (Nunez, 2009). Partimos do pressuposto que indícios de aprendizagem pudessem revelar o potencial da atividade.

\section{1 o Encontro (situação desencadeadora 1): Discussão sobre o conceito de metal pesado e o possível problema vinculado a sua presença em cosméticos e na natureza.}

De forma geral, todos os alunos conheciam a definição mais tradicional de metal pesado, no que diz respeito a sua alta densidade ou massa específica, bem como o seu número atômico elevado. As situações desencadeadoras organizadas visaram aproximar os estudantes de um conhecimento historicamente acumulado (Moura, 2010). Para que a aquisição de um conceito mais amplo ocorresse de maneira sistematizada e consciente, a mediação dos pesquisadores foi desenvolvida de modo a possibilitar ações reflexivas e consequente pensamento teórico por parte dos estudantes:

Aluno A/1 - (...) Como os químicos teriam que dar uma definição bem assim, clara, concisa de o que é o metal pesado para a comunidade numa entrevista televisiva, a gente pesquisou o seguinte, que normalmente quando se fala em metal pesado, pra maioria das pessoas eles logo remetem a quê? A alta "toxicidez" do metal, do elemento que tá se tratando, que normalmente é cádmio, chumbo. Mas nós, como químicos, deveríamos ter ideia de que o metal pesado, na verdade, ele é classificado como um metal pesado porque é assim: primeiro, porque ele é um metal; e segundo, porque ele tem uma alta massa específica ou densidade.

$$
\text { (...) }
$$

Pesquisador/1 - O aluno A/2 falou, por exemplo, que se tem um mercúrio lá no lago num estado de oxidação, no estado zero, a gente não sabe exatamente, e que a princípio não é tão prejudicial. Depois a planta de alguma forma fixa esse mercúrio, que também não parece tão prejudicial, que depois o peixe pode conseguir assimilar, porque aí já tem alguma coisa "dimetil”, segundo o que ele falou. Então espere aí, se vocês concordam com isso, até que ponto esse metal pesado é um problema? Todo metal pesado é um problema?

Aluno D/2 - Não. 
Pesquisador/1 - Queria que vocês falassem um pouquinho sobre isso. Vocês concordam com o que ele (o aluno $\mathrm{A} / 2$ ) tá falando?

Aluno D/3 - Sim.

Aluno D/4 - Sim, mas não é todos, porque...

Aluno D/2 - Em termos. Em termos, porque assim, olha, o metal pesado, ele é prejudicial a partir de um momento que ele chega a ser excessivo, como qualquer droga no nosso organismo. A água se for em excesso, ela vira uma droga, e não uma coisa saudável. Então o metal pesado, até onde eu entendi, a única coisa que modifica é que ele tem uma tolerância menor...

Aluno D/5 - De alguns...

Aluno D/2 - Você precisa do metal pesado para o seu organismo, pra você viver em alguns momentos...

Aluno D/5 - De alguns!!!

Aluno D/2 - De alguns, né?

Aluno D/5 - De alguns metais pesados.

Aluno D/6 - O cádmio, por exemplo, é um metal que não existe serventia nenhuma que... Assim, de benefícios para o ser humano, e pra ser vivo nenhum.

Aluno D/2 - Sim, mas...

Aluno D/6 - Agora, no caso no níquel, por exemplo, ele ativa a proteína... A vitamina " $A$ ".

Aluno D/4 - E o cobre ajuda na absorção de Vitamina $C$.

Aluno D/10 - O cobalto na produção de massa...

Aluno A/2 - O cromo, no estado de oxidação seis, ele é letal, é cancerígeno, mas...

Aluno D/6 - Quem?

Aluno A/2 - O cromo. Mas no estado três, ele é extremamente fun... Ele tem uma função celular importante, deixando de ser letal, mas ele tem uma função celular.

Aluno D/6 - E o cobalto o quê?

No início da discussão, a definição acerca de metal pesado era limitada, pautada no conceito geralmente apresentados pelos livros didáticos tradicionais (alta densidade, número atômico, etc). É possível notar nos trechos reproduzidos acima que assuntos referentes ao estado de oxidação, a tolerância, as possibilidades de o metal ser bom ou ruim (necessário ou prejudicial à saúde), foram sendo relacionados e formando 
nexos, possibilitando atingir um outro patamar de conhecimento sobre metais. Cada aluno possuía uma reflexão acerca do mesmo que foi compartilhada em meio a questionamentos, dúvidas e apontamentos. Cabe aqui, uma citação de Moura (2010) sobre a importância da mediação do professor para que a aprendizagem seja promovida:

Para que a aprendizagem se concretize para os estudantes e se constitua efetivamente como atividade, a atuação do professor é fundamental, ao mediar a relação dos estudantes com o objeto do conhecimento orientando e organizando o ensino. As ações do professor na organização do ensino devem criar, no estudante, a necessidade do conceito, fazendo coincidir os motivos da atividade com o objeto de estudo (pg. 94).

Pesquisador P/1 - Porque a discussão que eu queira levantar, com relação ao que aluno A/2 falou, que tem lá o metal que é necessário, segundo o que vocês estão falando, um que é mais prejudicial, menos, mas nem sempre a gente consegue assimilar esse metal. Segundo o que ele falou, se a planta não fixasse primeiro, o peixe não conseguiria assimilar, e muito menos o ser humano depois que vai comer esse peixe. Então, de novo, até que ponto o metal é um problema? Nem sempre a gente consegue assimilar esse metal. É isso que eu queria que vocês pensassem um pouquinho.

Aluno A/2 - Um exemplo interessante é o caso do bário. O bário é usado como extrato de... Pra fazer radiografia ou alguma coisa, que mexe com rádio. E ele é usado como um sal, é um sulfato de bário. O sulfato de bário, ele sai normal, mas o íon bário é perigoso. É o caso do “celobar”lá, com íon, então depende na forma com que o metal se encontra, e a densidade dele tá relacionada a isso.

Aluno D/2 - É, teve também o... Teve também o... Aquele episódio que ficou famoso, do contraste com o bário, se você reagir ele com reagentes diferentes, em vez. de ele virar um contraste, ele vira tóxico para o organismo, que foi o que aconteceu no hospital. Eu não lembro o que que era, se era sulfato, se era carbonato, não lembro qual dos dois que é tóxico e o outro que é só... Ele só é contraste.

Aluno D/8 - O tóxico é o carbonato.

Aluno D/2 - O carbonato. É. E o sulfato...

Uma elaboração racional desenvolvida pelos alunos buscou relacionar a toxicidade do celobar e suas representações com o problema vinculado aos metais pesados. No episódio sócio histórico relativo à fatalidade com este medicamento, a 
substância responsável pelo envenenamento (o metal bário), foi administrada na forma de seu carbonato (um composto que reage com ácido clorídrico do estômago, que por sua vez libera o metal no organismo). Acreditamos que este fato levantado pelos alunos, contribuiu para que a necessidade (conceito metal pesado) se materializasse no objeto.

Para Davidov (1988):

(...) a necessidade da atividade de estudo estimula os escolares a assimilar os conhecimentos teóricos, os motivos (estimula os escolares) a assimilar os procedimentos de reprodução desses conhecimentos por meio de ações de estudo, dirigidas a resolver as tarefas de estudo (p.178).

Em seguida, a discussão acerca do crômio e a relação de seus estados de oxidação com sua toxicidade por retomada pelo pesquisador.

Pesquisador/1 -(...) Segundo a fala do aluno A/2, ele falou: "Não, espera aí, o cromo três tudo bem, o cromo seis é letal". Então quando eu pego uma reportagem dessa, que foi feita por uma instituição científica que diz que tem cromo no batom, então espera aí, que cromo é esse? Que estado de oxidação é essa? Então tem um monte de coisa que a gente tem que pensar um pouquinho antes aí pra poder discutir, né?

Aluno A/1 - Mas a própria presença do elemento... Porque, por exemplo, a gente tem funções metabólicas no organismo que alteram as condições, por exemplo, função ácida, condições em que pegar próximo de neutro. Então essas condições alteram também a...

Pesquisador/1 - O estado de oxidação.

Aluno A/1 - O estado iônico dele. Então de três pra seis, ou de seis pra três.

Pesquisador/1 - Ele pode oxidar, ele pode...

Aluno A/1 - Ele pode oxidar ou não. Então a presença dele já pode ser considerada ameaça... Arriscada, porque dependendo do local onde ele estiver na presen... Das condições desse meio, ele pode mudar o seu estado e se tornar extremamente tóxico ou letal, ou também se tornar inofensivo, mas a gente não tem como controlar isso. Então a presença dele já é um alerta...

Pesquisador/1 - Um alerta. 
Aluno A/1 - E um motivo de preocupação também, porque a gente não tem condições de manipular todas as condições ambientais nas plantas, nos peixes, nos seres... No organismo vivo, na água, se ele estiver num esgoto, se ele estiver na estação de água e esgoto. Dependendo do momento em que ele tá, das condições desse ambiente, vai influenciar NOX e aí a gente pode ou não ter controle sobre ele.

A discussão sob qual forma o metal se constituiria num problema e em quais condições do meio, promoveu uma mobilização por parte dos sujeitos envolvidos. Esta é a condição "sine qua non" para que os alunos viessem a se apropriar do conhecimento novo. Quando estamos discutindo um problema de ordem científica, não podemos simplesmente pontuar que algo está certo ou errado. Faz-se necessário refletir sobre as condições externas e específicas do problema-alvo, para depois enumerar possibilidades, hipóteses e conclusões. Este fato corrobora para sustentar o potencial da AOE enquanto recurso metodológico, pois viabiliza a promoção do conhecimento.

Segundo Moura (2010),

(...) os sujeitos, mobilizados a partir do movimento de desenvolvimento da situação desencadeadora, interagem com os outros segundo as suas potencialidades e visam chegar a outro nível de compreensão do conceito em movimento (p. 103).

Neste ponto, iremos abordar a discussão desenvolvida acerca dos temas bioacumulação e biomagnificação ${ }^{4}$, bem como retomar a discussão acerca da

\footnotetext{
${ }^{4}$ Bioacumluação e biomagnificação: A bioacumulação (ou bioconcentração) ocorre quando determinada substância é absorvida por um organismo diretamente no ambiente. Por se apresentar a uma taxa maior do que o organismo consegue eliminar, acaba sendo acumulada pelo mesmo. Por exemplo, um peixe absorveu determinada quantidade de metil mercúrio em um lago qualquer.

Já a biomagnificação corresponde ao aumento da concentração de uma determinada substância ao longo da cadeia alimentar. Por exemplo, nós consumimos vários peixes ao longo de um ano. Se cada um deles estiver contaminado com aquela determinada quantidade de metil mercúrio $\left(\mathrm{CH}_{3} \mathrm{Hg}\right.$ ) (citada no exemplo da bioacumulação), nosso organismo experimentará uma aumento na concentração desta substância.

Fonte: Lima, V.F., Merçon, F. (2011). Os metais pesados no Ensino de Química, Revista Química Nova na Escola, 33 (4), (pp. 199 - 205).
} 
influência da forma em que se encontra o metal. Quando questionado acerca do referido tema, o aluno D/6 respondeu o seguinte:

Aluno D/6 - Bioacumulação não seria, tipo, acúmulo de energia? A vaca que come a planta, aí acumula energia, aí o ser humano vai lá e como a vaca. Tipo, é uma acumulação de energia na cadeia alimentar.

Pesquisador P/1 - Isso que eu to perguntando pra vocês, se vocês acham que é isso ou se alguém discorda.

Aluno D/6 - Mas não esse tipo de bioacumulação de metais. Envolve, engloba tudo, é energia pra...

Pesquisador P/1 - Então eu vou reformular de outra forma a questão então.

Aluno D/4 - Eu acho que não é.

Pesquisador P/1 - Nós temos duas situações, que eu acho. Pensem num indivíduo único, que pode ser o exemplo do peixe, ... se nesse rio tiver sendo despejado resíduos de metais pesados e ao longo da vida desse peixe, ele vai ficar recebendo essas concentrações de alguma forma, está disposto a receber essas concentrações, esse mesmo peixe,... isso é uma situação. Isso é uma bioacumulação? E tem a outra situação, que é a que vocês acabaram de falar, o peixe recebe esse metal, assimila, a gente vai, come o peixe etc. e tal, que tem a ver com cadeia alimentar. As duas coisas são bioacumulação? O que vocês acham?

Aluno D/5 - Bom, eu não compreendo o primeiro caso como sendo bioacumulação. Veja bem...

Aluno A/1 - Mas a gente tá falando a mesma coisa, eu acho.

Pesquisador/1 - Hã. Então me fale mais sobre isso, por favor.

Aluno D/5 - Eu vou citar o mesmo exemplo, o do Japão. Tem um resíduo, o resíduo vai para o rio, é absorvido por algum tipo de planta.

Pesquisador P/1 - Sim.

Aluno D/5 - Essa planta faz parte da cadeia alimentar do peixe.

Pesquisador P/1 - O peixe como a planta.

Aluno D/5 - Parte pelo menos de metal pesado que havia na planta vai para o peixe, e aquilo fica no peixe. E vai indo assim. O homem come o peixe, então parte da concentração de metal pesado que tava no peixe vai para o homem. 
Pesquisador P/1 - E aí?

Aluno D/5 - E aí quando entra para o homem, aí o metal...

Pesquisador/1 - E você considera então que isso não seria uma bioacumulação?

Aluno D/5 - Não, isso é. Isso eu entendo como uma bioacumulação.

Aluno A/1 - Não, isso é uma bioacumulação.

Pesquisador P/1 - Muito bem.

Os trechos acima relatados exemplificam a necessária intervenção do professor, de modo a facilitar que os alunos estabeleçam nexos. Pelo fato de haver certa divergência por parte dos alunos sobre os conceitos de biomagnificação e bioacumulação, o pesquisador precisou reorganizar suas ideias e mediar à discussão:

A qualidade de mediação da AOE a caracteriza como um ato intencional, o que imprime uma responsabilidade impar aos responsáveis pela educação escolar. Esta entende-se, é primordialmente a responsável pela aprendizagem de conceitos científicos e pelo desenvolvimento do pensamento teórico, orientada pela intencionalidade de impactar os sujeitos, proporcionando as alterações no desenvolvimento de suas funções psíquicas e a apropriação de conceitos científicos (MOURA, 2010, p. 99).

Podemos aqui, retomar ainda a teoria de Galperin (2001) em que três momentos podem ser destacados: primeiro precisamos desenvolver a forma adequada da ação, depois encontrar uma forma de representação desta ação e por fim, interiorizála:

Quando se estrutura uma ação completamente nova, sua forma é primeiro material, em seguida verbal e, por último mental, possibilitando que as funções mentais superiores se desenvolvam. Dessa forma, prestam-se as ajudas necessárias ao aluno durante $o$ processo de formação dos conceitos (NUNEZ, 2009, p. 94).

Ou seja, nesta discussão sobre bioacumulação e biomagnificação, os alunos apresentaram exemplos materiais (vaca se alimentando da planta, peixe contaminado, etc) e verbalizaram a possibilidade de consumo em cadeia alimentar, o que a nosso ver, 
permitiu, por meio da mediação dos professores/pesquisadores, uma correto entendimento dos conceitos citados.

E a discussão continuou:

Aluno A/1 - Porque assim, o que... Eu acho que é a mesma coisa que ele tá querendo dizer. É que o nosso organismo é que trava por causa dos metais pesados, ele não vai fazer o que ele deveria fazer. Ele vai ser inibido por causa dos metais pesados. Isso a gente... O estudo não foi... Eu não pesquisei nada sobre isso em outros tipos de animais, então eu não sei...

Pesquisador P/1 - Mas na Minamata ${ }^{5}$ lá do Japão, um monte de peixe morreu com o mercúrio, então talvez...

Aluno A/1 - Não, mas a concentração lá tava muito grande.

Aluno D/7 - É. Não tava igual. É absurda.

Aluno A/1 - É absurda.

Pesquisador P/1 - Então, de novo, depende da concentração, da exposição.

Aluno A/1 - Depende da concentração, do tempo de exposição e das condições do meio.

Aluno D/8 - E da espécie química que o metal se apresenta.

Nesta discussão, alguns nexos foram constituídos por meio do acidente ambiental de grande repercussão na história - o desastre na cidade de Minamata - na década de 30 no Japão. Para Moura (2002, p. 157), "tomar o ensino como uma atividade implica definir o que se busca concretizar com a mesma, isto é, a atividade educativa tem por finalidade aproximar os sujeitos de um determinado conhecimento”.

Esta situação proporcionou ao aluno vivenciar o surgimento histórico e social do conceito. Eles foram capazes de reconstituir por meio destes nexos, qual seria o

\footnotetext{
${ }^{5}$ Acidente em Minamata (Japão): Na década de 30, uma empresa responsável pela produção de acetaldeído lançou resíduos contendo mercúrio nos rios, contaminando toda a área. Em 1956, começaram a aparecer os sintomas na população, dentre eles problemas no cérebro, musculares, deficiências visuais, dificuldades de fala, paralisia e morte. Centenas morreram e anomalias foram perpetuadas de geração em geração.

Fonte: http://www.cetem.gov.br/mercurio/semiquanti/por/caso minamata.htm
} 
problema relacionado à exposição de um metal pesado, as concentrações disponíveis do mesmo, e como este atingiria diferentes animais de variadas formas.

\section{$2^{\circ}$ Encontro (situação desencadeadora 2): Proposta coletiva de rota de separação para os metais encontrados em batons dos EUA.}

Para iniciar este segundo encontro, os pesquisadores anotaram na lousa uma "amostra teórica" contendo os metais encontrados nos cosméticos dos EUA - Chumbo $(\mathrm{Pb})$, Cádmio $(\mathrm{Cd})$, Alumínio $(\mathrm{Al})$ e Crômio $(\mathrm{Cr})$ e inseriram um cátion extra, Mercúrio I (Hg I), com o intuito de complementar os cátions representantes do grupo analítico $\mathrm{V}$ (figura 5).

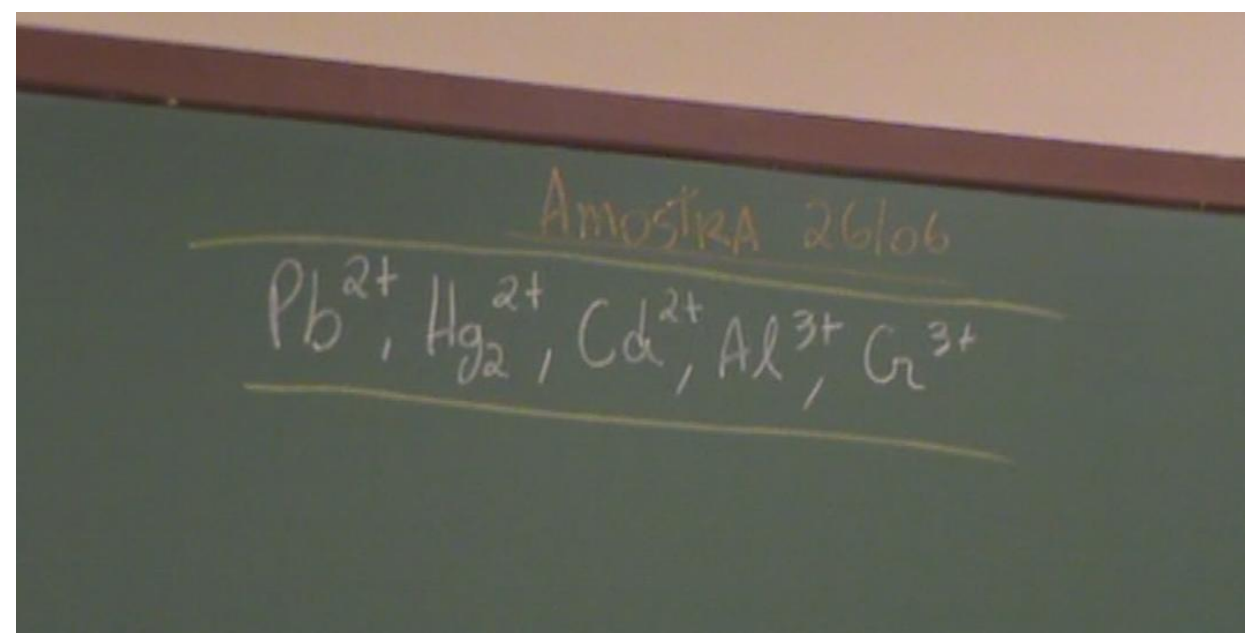

Figura 5: Amostra teórica de metais.

O aluno A/1 foi à lousa (figura 5) e iniciou a discussão com os demais sobre como separar estes metais. Houve um consenso sobre a adição inicial de cloreto (por meio do ácido clorídrico - equações 1 e 2) ao sistema e consequente precipitação do chumbo e mercúrio.

Equação 1: $\mathrm{Hg}_{2}{ }^{2+}{ }_{(\mathrm{aq})}+2 \mathrm{Cl}^{-1}{ }_{(\mathrm{aq})} \rightarrow \mathrm{Hg}_{2} \mathrm{Cl}_{2(\mathrm{~s})}$

Equação 2: $\mathrm{Pb}^{2+}{ }_{(\mathrm{aq})}+2 \mathrm{Cl}^{-1}{ }_{(\mathrm{aq})} \rightarrow \mathrm{PbCl}_{2(\mathrm{~s})}$ 
Todavia, dúvidas sobre solubilidade surgiram nesse momento e serão reproduzidas a seguir.

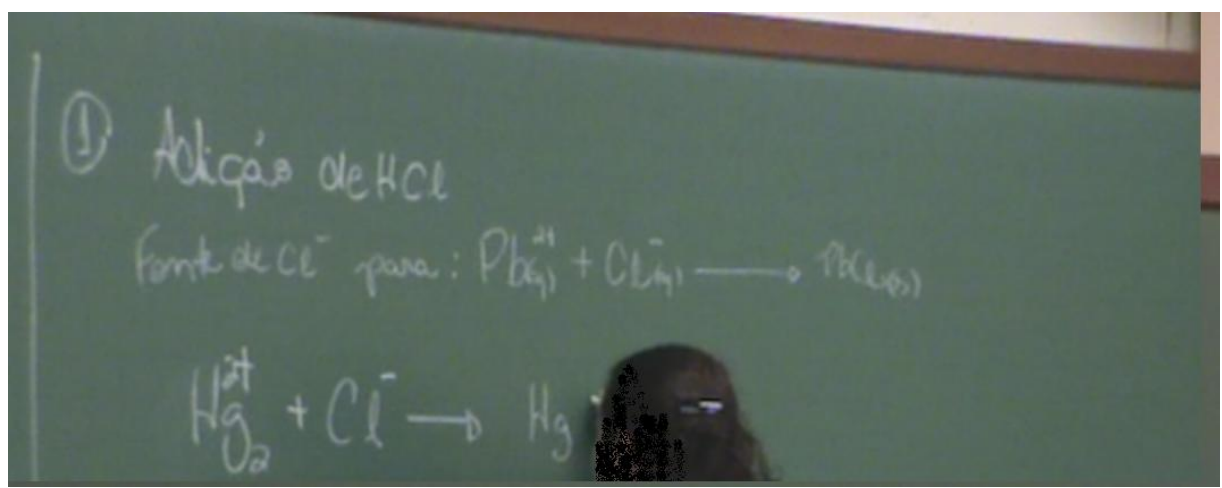

Figura 6: Aluno A/1 mediador inicial da discussão

Aluno A/1 - Então vai ter mercúrio ${ }^{6}$ também?

Pesquisador P/1 - O aluno A/1 tá perguntando... vai ter mercúrio também precipitado ali... e ai gente???

Aluno A/2 - De acordo com aquela equação sim (risos).

Aluno A/1 - O chumbo inteiro...é...todo o chumbo vai precipitar com o cloreto?

Pesquisador P/1 - Olha essa pergunta...todo o chumbo vai precipitar...e aí, que vocês acham???

A/3 - Não... o chumbo é parcialmente solúvel...

${ }^{6}$ Estados de oxidação do mercúrio: O mercúrio forma compostos em dois estados de oxidação, $+1 \mathrm{e}+2$, sendo que ambos são relativamente estáveis. No estado de oxidação +1 , o íon existe como um dímero ${ }^{+} \mathrm{Hg}_{-} \mathrm{Hg}^{+}$, ou $\mathrm{Hg}_{2}{ }^{2+}$ e este desproporciona de acordo com o equilíbrio a seguir: $\mathrm{Hg}_{2}{ }^{2+} \leftrightarrow \mathrm{Hg} 2^{+}+\mathrm{Hg}$. A constante de equilíbrio para esta reação é $\mathrm{K}=1,28 \cdot 10^{-4}$. Pelo valor de $\mathrm{K}$, pode-se concluir que os compostos mercurosos são estáveis. Não se decompõe facilmente em $\mathrm{Hg}^{0} \mathrm{e} \mathrm{Hg}^{2+}$. No entanto, quando $\mathrm{Hg}^{2}$ + forma um sal pouco solúvel como $\mathrm{HgS}, \mathrm{Hg}\left(\mathrm{NH}_{2}\right) \mathrm{Cl}$ ou um íon complexo como $\left[\mathrm{HgCl}_{4}\right]^{2-}$, este equilíbrio é deslocado para a direita devido à remoção dos íons $\mathrm{Hg}^{2+}$ da solução. Desta forma, as reações seguintes são favorecidas: $\mathrm{Hg}_{2} \mathrm{Cl}_{2(\mathrm{~s})}+2 \mathrm{NH}_{3(\mathrm{aq})} \rightarrow \mathrm{Hg}_{(\mathrm{s})}^{0}+\mathrm{HgNH}_{2} \mathrm{Cl}_{(\mathrm{s})}+\mathrm{NH}_{4}{ }^{+}{ }_{(\mathrm{aq})}+\mathrm{Cl}_{(\mathrm{aq})}^{-}$; $\mathrm{Hg}_{2}^{2+}{ }_{(\mathrm{aq})}+\mathrm{S}_{(\mathrm{aq})}^{2-} \rightarrow \mathrm{Hg}_{(\mathrm{s})}^{0}+\mathrm{HgS}_{(\mathrm{s})}$

Fonte: Baccan, N.; Aleixo, L. M.; Stein, E.; Godinho, O. E. S.; Introdução à Semimicroanálise Qualitativa, 7a ed., Editora da UNICAMP: Campinas, 1997. 
Pesquisador P/1 - Então, provavelmente vai ter alguma coisa pra cá então, solubilizado... (se referindo ao lado esquerdo da marcha que estava sendo construída).

Aluno A/1 - Aí, quando eu adiciono ácido, o pH aqui já vai "tá” ácido... eu tenho que adicionar mais ácido?

Pesquisador P/1 - E ai gente???

Aluno A/2 - Então, eu li no "Baccan", que é "pra" adicionar ácido para não precipitar o sulfeto do grupo III.

Pesquisador P/2 - A sua lógica tá correta...Na prática, é isso que a gente faz será???

Aluno A/4 - Tem que precipitar o alumínio como hidróxido...

Pesquisador P/2 (e demais alunos concordando) - Não, ainda não...

Aluno A/3 - Na verdade, tem que ver quanto ácido "tá"..

Aluno A/1 - põe checagem de pH então??

Alunos - isso, isso!

Pesquisador P/1 - Então perai, a gente tem que pensar numa forma pra chegar este $\mathrm{pH}$, qual seria o pH para precipitar grupo IV?

Aluno A/1 - Então, tem que ver na tabela de Kps.

Pesquisador P/1 - O aluno A/2 tá dizendo que leu que é pH meio...Por que vai ser meio ácido???

Aluno A/1 - Porque se for básico, aumenta a concentração de sulfeto e atinge o Kps do grupo III...

Pesquisador P/1 - Então, quer dizer que esse já seria o requisito para separar o IV do III?

Alunos - É...Isso...

Percebemos que conceitos relativos à separação dos grupos analíticos III e IV foram assimilados por parte dos alunos. Até então, eles não tinham desenvolvido experimentos em que os metais de ambos os grupos estivessem presentes em conjunto, uma vez que o IV não havia sido trabalhado antes da atividade. Todavia, nas falas apresentadas do aluno A/1, podemos detectar uma explicação coerente no que diz respeito à separação dos grupos III e IV. 
Na necessidade de explicar e argumentar o que se faz para comunicar outra pessoa será imprescindível a utilização da linguagem verbal em sua forma oral ou escrita, e é precisamente esta a tradução de uma lógica da ação para uma lógica dos conceitos, o que contribui para garantir que a ação seja consciente. (...) falando com os outros, (...) o aluno pode apropriar-se dos termos linguísticos próprios da disciplina e pode desenvolver estratégias metacognitivas de aprendizagem (NUNEZ, 2009, p. 122).

Os metais constituintes dos grupos III e IV podem ser precipitados na forma de sulfetos ( $\mathrm{S}^{2-}$, Quadro 1), mas em meios reacionais diferenciados. A constante do produto de solubilidade (Kps, em anexo) é distinta para cada grupo. Os cátions do grupo III apresentam maiores valores de Kps e consequentemente, necessitam de maiores concentrações de sulfeto disponibilizado para a sua precipitação. Esta condição é atingida em sistemas básicos, cuja disponibilidade de sulfetos é maior devido ao deslocamento do equilíbrio (equação 3).

$$
\text { Equação 3: } \mathrm{H}_{2} \mathrm{~S}_{(\mathrm{g})} \leftrightarrow 2 \mathrm{H}^{+}{ }_{(\mathrm{aq})}+\mathrm{S}^{-2}(\mathrm{aq})
$$

Já os cátions do grupo IV apresentam menores valores de Kps, necessitando assim de menos sulfeto disponível para a sua precipitação (equação 3 e 4). Esta possibilidade é favorecida em meios ácidos, devido ao deslocamento do equilíbrio no sentido inverso em relação aos sistemas básicos.

Equação 4: $\mathrm{Cd}_{(\text {aq })}^{2+}+\mathrm{S}_{(\text {aq })}^{-2} \rightarrow \mathrm{CdS}_{(\mathrm{s})}$

Equação 5: $\mathrm{Pb}^{2+}{ }_{(\mathrm{aq})}+\mathrm{S}_{(\mathrm{aq})}^{-2} \rightarrow \mathrm{PbS}_{(\mathrm{s})}$

Assim, nesta etapa do experimento é necessário o devido cuidado em não precipitar dois os grupos de uma única vez, fato que inviabilizaria a separação pretendida. Esta etapa nos pareceu importante para exemplificar o nível de consciência dos alunos.

E o pesquisador continuou, orientando a discussão, agora para a concentração do reagente ácido clorídrico a ser utilizado: 
Pesquisador P/1 - Tá, beleza, então agora falta a gente discutir qual vai ser a concentração desse ácido clorídrico ai...

Aluno A/5 - Eu acho que tem que ser ácido concentrado...

Aluno A/3 - Eu acho que tem que trabalhar com o Kps....

Aluno A/6 - Eu acho que tem que ter um ligeiro aumento de ácido clorídrico para precipitar ali o chumbo e o mercúrio...se tiver muito, também fala que forma complexo solúvel...Não dá para jogar um ácido super concentrado,...e também desprecipitar....

Pesquisador P/2 - Deixa eu só perguntar uma coisa ...vocês lembram de algum evento quando vocês mudavam de grupo, o que é que vocês faziam???

Aluno A/3 - Elimina a tioacetamida...

Aluno A/4 - Elimina a tioacetamida com ácido e aquecimento, faz o teste com o papelzinho de cádmioo,...

Pesquisador P/1 - Mais alguma coisa??

Aluno A/4 - Tem que levar a secura...

Aluno A/2 - É e o pH tem que estar $5 . .$.

Pesquisador P/1 - Isso é uma coisa para a gente conversar um pouquinho também, toda vez que a gente sair de um grupo e entrar em outro, vamos ter que levar a secura - como ele disse lá - ...por que levar a secura?

Aluno A/4 - Nesse caso, para eliminar o excesso de ácido, não é ???

Aluno A/5 - Você vai ter o íon diluído, você levando a secura, você vai ter os íons alí seco. os sais dos íons que você quer, então como é feito.., você pega a porcelana, goteja pouca água para não diluir muito...

Pesquisador P/1 - E aí, vocês concordam? Para concentrar, para eliminar ácido ou algum interferente, que possa ser interferente para a próxima etapa..

Alunos - Sim, sim (palavras e movimentação da cabeça em sinal afirmativo).

Pesquisador P/1 - Ó gente, é importante tomar nota disso, porque amanhã é isso que a gente vai ter (fazendo referência ao laboratório), então se vocês tão colocando ai "levar a secura", tem que anotar que amanhã vocês vão ter que levar a secura...

Aluno A/2 - Qual parte? (risos)...

Pesquisador P/1 - Qual parte???

(momento de confusão e falas conjuntas) 
Aluno A/7 - Na hora que sai do Ve vai para o IV...

Aluno A/5 - É do III...

Aluno A/2 - Do IV para o III...

Pesquisador P/2 - Eu acho que a gente precisa de terminar o grupo $V$, ai sim... (fazendo referência a continuação da construção da marcha, como possibilidade de clareamento das ideias).

A princípio a ação verbal se estrutura como um reflexo verbal exato da ação realizada com o objeto ao qual o sujeito faz referência o tempo todo e se esforça por "representá-lo" para si. Mas depois, a "representação dos objetos" é cada vez mais fraca $e$ o significado das palavras com as quais se expressa a ação se compreende cada vez mais "diretamente" (GALPERIN, 2001c, p. 49).

Neste trecho evidenciado, os alunos concluíram a necessidade de se levar a amostra à secura. Mas havia ainda uma insegurança no que diz respeito ao motivo pelo qual se deveria desenvolver esta etapa, bem como em qual(is) momento(s) do experimento esta prática deveria ser desenvolvida. Esta tentativa de do sujeito em representar "a ação realizada para si", foi importante para que as conclusões conseguintes fossem obtidas.

Imaginar o produto final das ações no laboratório, em relação aos procedimentos e condições para ação é fundamental no processo de interiorização (Nunez, 2009).

$O$ aluno antes de fazer, deve ter claras compreensões do que vai fazer, com possibilidades de argumentar as ações que conformam a atividade que vai desenvolver. Ao construir o modelo teórico, pelo qual poderá desenvolver a atividade, o aluno precisa conscientizar-se da estrutura da atividade (NUNEZ, 2009, p. 84 e 85)

Pesquisador P/1 - E aí gente, naquelas duas situações que já tem ali (figura 6), tem que levar a secura ou não? 


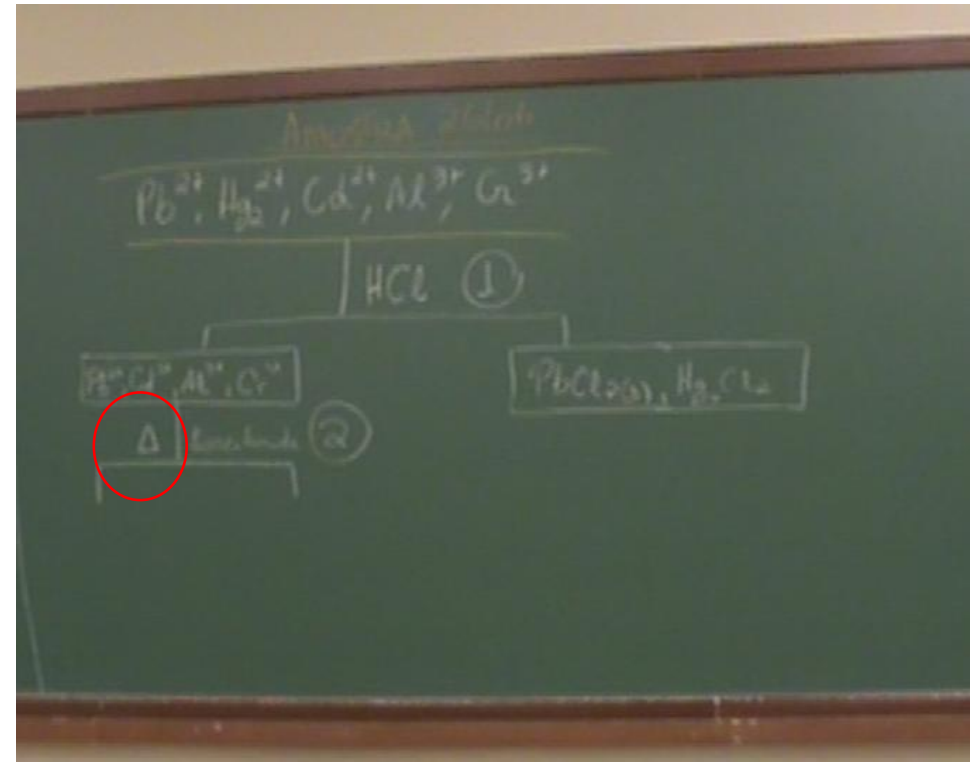

Figura 7: Continuação da rota - levar à secura $(\Delta$, símbolo aquecimento)

Aluno A/5 - Sim,.... Então ali, você vai ter que fazer a secura antes de por a tioacetamida, porque você tem o chumbo no IV, então você tem que primeiro, tirar ele...

Precisamos enfatizar que levar a solução à secura não eliminaria o chumbo como dito pelo aluno A/5. Acreditamos que o aluno em questão, fez referência a não precipitação do chumbo (Equação 2). Como dito anteriormente pelos próprios alunos, o chumbo possui determinada solubilidade e não precipitará totalmente como cloreto. $\mathrm{O}$ aquecimento eliminaria o excesso de ácido.

Acreditamos ser importante apresentar a fala deste aluno (evidenciada no segundo encontro teórico) para compará-la com o que o mesmo aluno formulou e desenvolveu durante o experimento. Houve uma mudança de postura que será apresentada durante os resultados do terceiro encontro - experimental.

(...)

No trecho abaixo, está relatado outro momento da discussão, onde após separar o grupo V do IV, e o grupo IV do III, havia a necessidade de separar os metais do grupo III entre si (Crômio e Alumínio). À priori, todos os alunos sugeriram como meio reacional o tampão amônio/amônia em $\mathrm{pH}$ 9, fato que levaria todos os metais à hidróxidos.

Pesquisador P/1 - Se eu precipitar todo mundo como hidróxido, segundo essa opção de vocês, como eu vou identificar depois cromo e alumínio?

Aluno D/1 - Depois adiciona em excesso, complexa o alumínio. 
Pesquisador P/1 - Boa. O alumínio, ele pode ir a complexo se tiver um excesso de hidróxido.

Aluno D/7 - Mas o cromo também.

Pesquisador P/1 - O cromo também. Então temos uma dificuldade, então.

Aluno D/1 - E aí?

Aluno D/3 - Aí tem intervalo na concentração, porque não é no mesmo pH que eles se tornam complexos.

Pesquisador P/1 - Então quer dizer que tem uma possibilidade de eu fazer um complexo de um dos cátions e o outro não.

Aluno D/1 - Qual é a região de pH que complexa o crômio?

Aluno D/3 - Alumínio, acho que é 11; o cromo é 13. Não é?

Aluno D/1 - Aí, já dá pra...

Pesquisador P/1 - Então já é possível?

Aluno D/1 - Já.

Todavia, para o crômio não complexar em presença de base forte, seria necessário adicionar um agente redutor (água oxigenada) para que o Crômio III fosse oxidado a Crômio VI. A separação destes metais por uma diferença mínima de pH (11 e 13) não seria garantida.

A seguir, será relatado como os alunos conseguiram chegar a esta conclusão, mediados pelos pesquisadores. Precisamos destacar a importância da linguagem para o estabelecimento deste processo conclusivo.

(...)

Pesquisador P/1 - Você quer que aconteça o que com o Crômio?

Aluno A/3 - Que ele vai de Crômio III para Crômio VI? (fazendo referência a formação do cromato)

Pesquisador P/1 - E isso é o que?

Aluno A/3 - Isso é oxidação...

Aluno A/8 - Tem que por um agente redutor...

Aluno A/1 - Então só com um excesso de base já vai fazer? (Este questionamento do aluno $\mathrm{A} / 1$ foi importante para que os alunos refletissem sobre a necessidade de se inserir um novo reagente) 
Pesquisador P/1 - E aí gente?

(depois de um tempo de silêncio)

Aluno A/9 - Ooo "P/1" pode oxidar com álcool? Ééé...o bafômetro lá,..o mesmo pensamento do bafômetro?

Pesquisador P/2 - É, o mesmo pensamento do bafômetro ${ }^{7}$ (fazendo referência a mudança de coloração, forma pela qual precisaríamos identificar o crômio em nosso experimento),...E o que acontece no bafômetro???

Aluno A/9 - Você adiciona um álcool, ele vai reagir, e vai oxidar o crômio de III para VI e vai mudar de cor...

Pesquisador P/2 - E o que acontece com álcool? (com o intuito de que o aluno reformulasse suas reflexões, uma vez que o álcool é que será oxidado no bafômetro - e não o crômio)

Aluno A/9 - Ele vira, ai...aldeído...ixi..não...álcool, outro nome de álcool...

Aluno A/10 - Vira Ácido!!!

Pesquisador P/2 - O álcool vai ser o quê???

Aluno A/9 - Ele vai ser reduzido... elee vai formar..ácido...aquele outro nome lá...é da inorgânica...da orgânica..(Mas o álcool é oxidado e assim o pesquisador continuou...)

A discussão relatada acima, em que o aluno A/9 participou mais efetivamente, evidencia a importância da linguagem no processo de desenvolvimento mental, vinculado à experiência sócio histórica da humanidade. $\mathrm{O}$ aluno em questão, fez uma alusão ao princípio do bafômetro - utensílio conhecido da sociedade de forma geral - e a partir dai, tentou estabelecer o conceito de identificação do crômio a ser utilizado no experimento.

\footnotetext{
${ }^{7}$ Reação do bafômetro: Se o ar colhido no bafômetro apresentar álcool, este será oxidado a aldeído e o crômio VI (alaranjado) existente no bafômetro será reduzido a crômio III (verde) - em uma reação de oxirredução. A mudança de coloração neste instrumento é o indicativo da presença de álcool no organismo do sujeito em análise.
}

$\mathrm{K}_{2} \mathrm{Cr}_{2} \mathrm{O}_{7(\text { (aq) }}+4 \mathrm{H}_{2} \mathrm{SO}_{4(\mathrm{aq})}+3 \mathrm{CH}_{3} \mathrm{CH}_{2} \mathrm{OH}_{(\mathrm{g})} \rightarrow \mathrm{Cr}_{2}\left(\mathrm{SO}_{4}\right)_{3(\mathrm{aq})}+7 \mathrm{H}_{2} \mathrm{O}_{(\mathrm{l})}+3 \mathrm{CH}_{3} \mathrm{CHO}_{(\mathrm{g})}+\mathrm{K}_{2} \mathrm{SO}_{4(\mathrm{aq})}$

ALARANJADO ÁLCOOL VERDE ALDEÍDO


Para Nunez (2009),

$\mathrm{Na}$ aprendizagem, a linguagem é uma condição importante para o desenvolvimento mental, porque o conteúdo da experiência histórica do homem, a experiência histórico social, não está consolidado somente nas coisas materiais, mas está também distribuído e refletido na forma verbal da linguagem. A linguagem simbólica é um agente essencial no processo de internalização. Aprender é também utilizar a informação, e não somente memoriza-la (p. 111).

Assim, o aluno em questão utilizou a informação do bafômetro na tentativa de estabelecer nexos. Apresentou o fenômeno ocorrido no mesmo, bem como as disciplinas cursadas na graduação de química orgânica e inorgânica. Inicialmente a ideia estava um tanto equivocada e foi trabalhada por meio da mediação dos pesquisadores e demais alunos participantes da atividade.

Dando continuidade, o pesquisador P/1 fez uma interferência com o intuito de focalizar a discussão de como se daria a separação e identificação do crômio na amostra:

Pesquisador P/1 - Deixa eu tentar construir aí... a gente quer que o crômio vá de III para VI, todo mundo concorda com isso??? Então o crômio, segundo o que vocês falaram tem oxidar, sim?

Aluno A/1 - Ah, mas não precisar fazer isso para eu separar ele...não precisa ir de III para VI!!

Pesquisador P/1 - Não?

Pesquisador P/2 - Aaah, tá faltando uma informação aí!!!

Aluno A/3 - Até porque, se a gente for fazer assim, vai ter que tratar ele depois (se referindo ao crômio VI)

Aluno A/7 - E se co-colocar água oxigenada? (voz com insegurança)...

Pesquisador P/2 - Peróxido?!

Aluno A/7 - É, peróxido...ele vai oxidar! Pode por peróxido?

Pesquisador P/1 - Sim (sinal positivo com a cabeça)

Pesquisador P/2 - Tá faltando uma etapa aí, é importante vocês conhecerem a propriedade do alumínio e do crômio...

Alunos - Eles são anfóteros... 
Pesquisador P/2 - Ambos?

Aluno A/7 - Não, só o alumínio!

Pesquisador P/1 - Cadê o material do grupo III, vocês trouxeram o material do grupo III, dá um olhada lá?

Alunos - Sim, sim!

Pesquisador P/2 - E aí, você entenderam por que que o autor mandou oxidar?

Aluno A/7 - Porque senão os dois, vaai..(quando é interrompido pelo aluno $\mathrm{A} / 2)$

Aluno A/2 - Você não consegue separar os dois não é?

Aluno A/7 - Então mais vai ter o caráter do mesmo jeito, vai continuar juntos...

Pesquisador P/2 - Bom, e aí?

Aluno A/7 - Aí coloca água oxigenadaa!

Pesquisador P/2 - Agora vocês tem condições de dizer como separar, se ambos são anfóteros...(quando é interrompido pelo aluno A/1)

Aluno A/1 - Então, mas o alumínio é em pH 11 só..e o crômio em pH 13, só por essa diferença eu não consigo separar?

Pesquisador P/2 - Mas a gente não garante, porque o meio é muito básico...você não consegue controlar em condições naturais, a concentração de $\mathrm{OH}^{-}$, você percebeu??

Então o aluno A/1 voltou a lousa e apagou o trecho da marcha na qual pretendia separar crômio e alumínio por diferença de $\mathrm{pH}$ dos complexos.

Pesquisador P/2 - E então, tem que ser um método mais elegante para separar... E aí, coloca o que???

Alunos A/3, A/7 - Peróxido de hidrogênio!!!

Pesquisador P/2 - Peróxido de hidrogênio...é um oxidante!!!

Pesquisador P/1 - Vamos tentar concluir? Vai de crômio III para crômio VI, está oxidando o crômio concorda?

Alunos - (cabeça em movimentação positiva)

Pesquisador P/1 - A gente quer que o crômio oxide, alguém vai ter que reduzir, o que "cê" vai colocar, vai ter que reduzir, então é um agente oxidante! 
Aluno A/2 - Então a gente vai colocar ele (se referindo ao peróxido) junto com o excesso de base lá?

Pesquisador P/1 - Sim, exatamente.

Aluno A/2 - Então coloca $\mathrm{OH}^{\top}$ e peróxido...

Aluno A/3 - Então mantém em meio alcalino.... eu posso manter em meio alcalino..não interessa se ôoo..

Pesquisador P/2 - Vai lá para ajudar!!!

( o aluno A/3 foi também foi a lousa)

Aluno A/3 - Então, forma o hidróxido de alumínio, o hidróxido de crômio, dai eu coloco hidróxido de sódio e peróxido...

Aluno A/1 - Então, mas se eu colocar o excesso de base vai formar complexo de alumínio e com o prata, não, o cromato...e aí os dois vai ficar em solução?

Pesquisador P/2-Sim (sinal positivo). Aquela reação que você colocou aqui (foi até a lousa mostrar), você pode colocar o complexo aqui (deixando claro que primeiro é formado o complexo de crômio e que depois ele é oxidado com a água oxigenada)

Aluno A/1 - Aah, tá!

Aluno A/1 (após anotar a continuação da marcha na lousa) - Então para separar, aí é só eu reduzir o pH que o alumínio volta a precipitar e crômio continua em solução?

\section{Pesquisador P/2 - Salve!!!}

Podemos retomar aqui o princípio do "caráter consciente", citado na fundamentação teórica deste trabalho. Neste, é evidenciado que a aprendizagem deve ser desenvolvida por meio de um processo consciente. Percebemos nos trechos destacados acima, que os alunos tinham material para ser consultado, mas foi necessária uma reflexão acerca do mesmo, bem como de suas adaptações, generalizações, transformações. 
Para Nunez (2009),

A consciência não é limitada à sucessiva expressão de abstrações verbais em relação com sua imagem sensorial, que, em sua essência, constitui o mecanismo interno do pensamento empírico $e$ classificador. Mas é uma consequência da assimilação dos procedimentos da atividade pelo aluno, da transformação dos objetos $e$ a apropriação dos meios de tais transformações ... (p. 138).

Entendemos que os alunos foram aos poucos assimilando a importância em se adicionar o peróxido de hidrogênio para otimizar a separação de crômio e alumínio (representantes do grupo III). Se adicionassem apenas base forte (hidróxido de sódio), ambos os metais iriam a complexo (pelo caráter anfótero que possuem). A adição deste peróxido (água oxigenada) levaria a oxidação do crômio III a crômio VI, o qual seria identificado pela mudança de coloração da solução (de verde para alaranjada).

(...)

Aluno A/1 - Mas aí eu posso fazer, por exemplo, pH 5 com ácido acético ou só adicionar ácido até precipitar o alumínio?

Pesquisador P/2 - O que vocês acham?

Pesquisador P/2 - E aí, quem garante? Como você comprova que isso é aluminio?

Aluno A/7 - Se tem que fazer pH 9 de novo, para ele precipitar como hidróxido de novo, ai sim...

Pesquisador P/2 - Tá, mas antes disso você vai fazer o quê? Para garantir?

Aluno A/2 - Vai acidificar com $\mathrm{HCl}$ (ácido clorídrico) 1 mol, ai vai precipitar, aquele precipitado gelatinoso, difícil de ver.

Pesquisador P/2 - Veja bem, nós estamos detalhando a identificação do alumínio e do crômio, o crômio vocês já identificaram - (fazendo referencia a mudança de coloração que ocorrerá na solução, assim como no bafômetro) - do alumínio vocês vão tentar identificar desta forma, ácido clorídrico...Aah, mas esta ainda não é a separação elegante que eu falei (risos)...

Aluno A/7 - $\mathrm{NH}_{3}$ (Amônia), não é??? Não é HCl e amônia, chegar ao tampão $9 ?$ 
Pesquisador P/2 - Isso!

Aluno A/2 - Éé, tem que colocar amônia...

Neste trecho, os alunos recorreram a conceitos relativos ao grupo III, já desenvolvidos em sala de aula e laboratório. Seria necessário a formação de um tampão (pH 9), para precipitação do referido hidróxido de alumínio. A utilização de reflexões racionais na discussão relatada parece ter proporcionado a apropriação do conhecimento acerca da separação entre os cátions do grupo III. Este momento se deu quando os alunos relataram a possibilidade de complexação de um dos cátions (alumínio) e posterior reprecipitação. Evidenciaram ainda a diferença de $\mathrm{pH}$, estabelecendo um nexo.

Por fim, houve um questionamento em relação aos precipitados de Chumbo e mercúrio (lado direito do inicio da marcha analítica que estava sendo construída na lousa).

Aluno A/1 - E esses daqui? (apontando os precipitados de chumbo e mercúrio) - Figura 8.

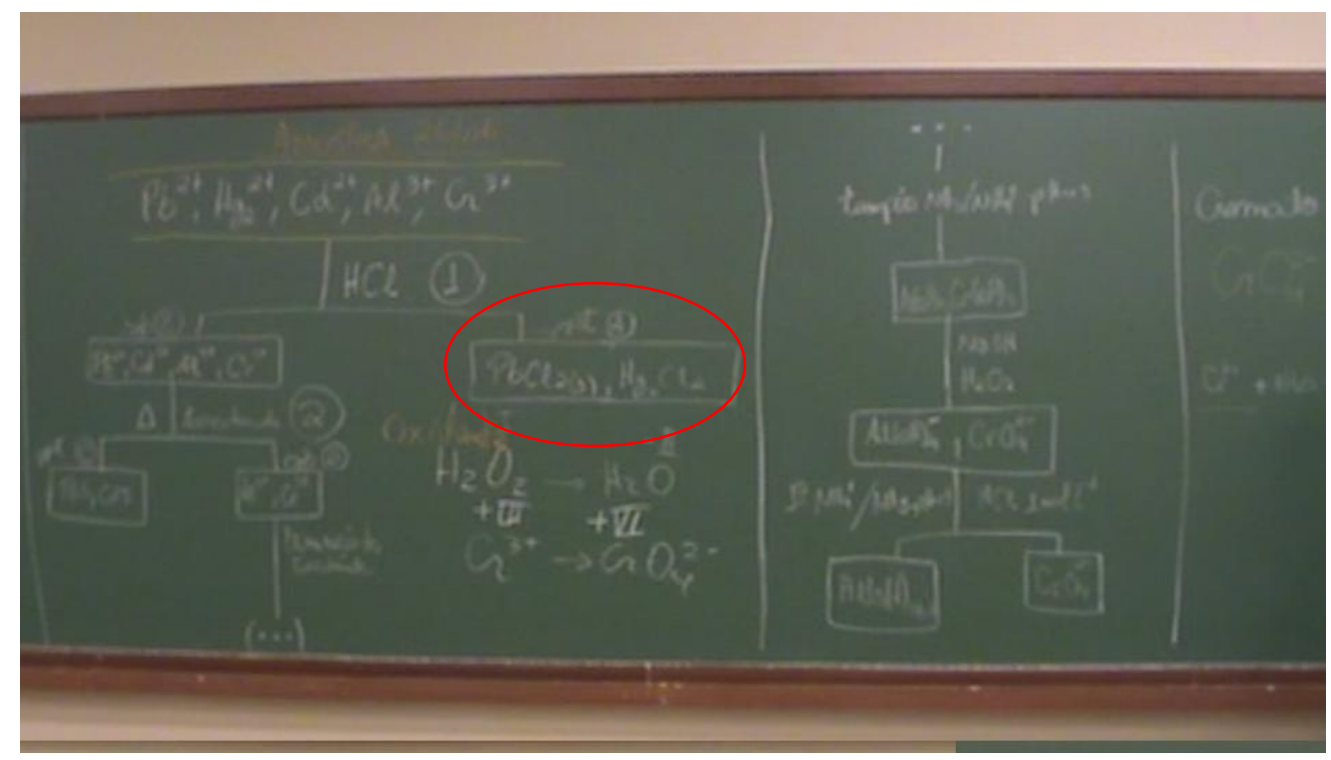

Figura 8: Visão geral da marcha analítica - destaque para os precipitados de chumbo e mercúrio I

Pesquisador P/1 - Não acabou ainda né gente (risos). E aí?

Aluno A/6 - Adicionar água quente né..

Pesquisador P/1 - Vem a lousa? 
Aluno A/6 - Não, o aluno A/3 vai...pode ir..

Neste momento, o aluno A/3 voltou a lousa.

Pesquisador P/1 - Que grupo o aluno A/3 está trabalhando agora?

Alunos - Grupo V, V!!!

A marcha analítica que foi paulatinamente construída na lousa, se configurou como uma possibilidade de materialização da ação de nossa atividade. $\mathrm{O}$ aluno $\mathrm{A} / 1$, ao experimentar esta possibilidade de materialização se atentou que havia dois precipitados (destacados com o círculo vermelho na figura 8), que ainda careciam de argumentação/discussão no que diz respeito às suas respectivas separações.

Assim, aproximamos a marcha analítica produzida durante a AOE do que Galperin (1986) nomeou de mapas da atividade. Estes mapas podem propiciar a individualização do processo, uma vez que após a construção coletiva, cada aluno testou e desenvolveu a sua utilização durante o terceiro encontro experimental.

O último trecho a ser relatado é referente à separação e identificação do cádmio existente na amostra (representante do grupo analítico IV). Vale ressaltar que teremos nesta solução também o metal chumbo que possui determinada solubilidade citada no início da discussão (chumbo II - outro representante do grupo IV).

(...)

Pesquisador P/1 - E aí, quem pode ir lá (fazendo referência a lousa)??? Se vai aluno A/5??

Aluno A/2 - Eu vou.

$\mathrm{O}$ aluno $\mathrm{A} / 2$ continuou a rota a partir do trecho que envolve a separação do cádmio e chumbo em diante. Este aluno possuía uma folha de rascunho em mãos. Após anotar que seria necessário adicionar ácido nítrico para solubilizar os precipitados (forma correta), o aluno anotou na lousa a adição do reagente glicerina, posteriormente ao cádmio estar solubilizado.

Neste momento o pesquisador $\mathrm{P} / 2$ interrompeu:

Pesquisador P/2 - Pra que que serve a glicerina?

Aluno A/2 - Tava no "Baccan”...Confesso que eu fiquei com dúvida nisso, pra que que serve essa glicerina...

Pesquisador P/2 - Alguém pode dizer porque no livro está glicerina? 
Aluno A/7 - Eu não entendi porque a glicerina, porque aqui fala que ele vai formar um óxido...

Pesquisador P/2 - Hidróxido!

Aluno A/7 - É, hidróxido...

Pesquisador P/2 - Tá, então não tem função...

Aluno A/7 - Mas é por causa do cobre! Porque aqui forma...eu não sei falar (risos), mas é cobre...(fez o sinal de parênteses com a mão), glicerina dois!

Pesquisador P/2 - É um complexo, é um complexo! Então ajuda explicar lá...

Aluno A/7 - É porque se você for fazer, com todos...éé...do grupo IV...aqui se tiver o cobre...nessee...

Pesquisador P/2 - Ajuda a explicar lá (sugerindo que o aluno também fosse a lousa).

O aluno A/7 foi a lousa:

Aluno A/7 - Se tivesse cobre junto aqui (sinalizando que além do cádmio do grupo IV, se na amostra tivesse o cobre também) Ai, nesse ponto, ele ia formar o complexo de cobre...Então no caso aqui, que a gente...como não tem o cobre, acho que não precisa usar...Foi por isso que eu não tinha colocado...

Pesquisador P/1 - E ai gente, a gente usa ou não usa glicerina???

Pesquisador P/2 - Agora eu faço uma segunda pergunta...se tivesse cobre, como é que o cádmio é identificado aí?? Eu quero que vocês me digam, porque da glicerina se tivesse cobre...

Aluno A/7 - Ai, ai já é muito avançado (risos).

Pesquisador P/2 - Não é avançado, olha lá (apontando a marcha analítica na lousa)...Você tá separando...esta é uma estratégia utilizada para separar cobre de cádmio.. Só isso, não é nada avançado... E por que não pode precipitar sulfeto de cádmio na presença do cobre?

\section{(silêncio total)}

Neste momento o pesquisador $\mathrm{P} / 2$ foi a lousa e apontou na marcha analítica o local onde aparece o sulfeto de cádmio:

Pesquisador P/2 - Se o cobre estivesse aqui, o que que formaria?

Aluno A/7 - Sulfeto de cobre..

Pesquisador P/2 - Que cor???

Aluno A/7 - Azul (entonação de dúvida) 
Pesquisador P/2 - Só o cádmio é amarelo... que cor???

Alguns alunos - Preto!!!

Pesquisador P/2 - Então vocês imaginam se vocês conseguiriam ver alguma coisa aqui com o cobre presente...(sugerindo que tudo estaria preto, e o sulfeto de cádmio sendo amarelo não seria visualizado).

Pesquisador P/2 - Resumo da ópera, precisava da glicerina???

Vários alunos - Não, não!!!

Esta explanação foi importante, porque evidenciou que os roteiros propostos pelos livros textos são gerais (estão prontos) e que em casos específicos o aluno precisa refletir sobre alternativas e diferentes possibilidades de separação e identificação. Mais uma vez enfatizamos que este tipo de prática pode favorecer a aprendizagem de forma consciente, como afirma Gonzalez (1991):

Só é possível chegar a um verdadeiro nível de consciência dos conhecimentos quando os alunos não o recebem já prontos, mas quando eles mesmos, em sua atividade, revelam as condições de sua origem e transformação (p. 34).

Assim também, reiteramos que foi importante à busca inicial desenvolvida pelos alunos sobre possibilidades de identificação e separação dos metais propostos. Eles trouxeram possibilidades que puderam ser consideradas como "um todo" bruto, a ser decomposto. Após várias discussões, reformulações, mudanças de postura e adaptações, iniciou-se a possibilidade de compreensão da lógica de separação da amostra existente (de nossa AOE).

Pesquisador $\mathbf{P} / 2$ continuou - E em que momento vocês fazem a identificação do cádmio?

Aluno A/7 - Logo lá no cádmio “dois mais”!

Aluno A/3 - Quando ele tá como...

Aluno A/2 - Não coloca o $\mathrm{NaOH}$ (hidróxido de sódio)

Aluno A/7 - Se já tiver cádmio “dois mais", já pode não pode?

Pesquisador P/2 - Mas aqui, como vai estar aqui, qual o meio?

Aluno A/5 - É, "cê”" tem que acertar o pH né... 
Aluno A/7 - É...

Pesquisador P/2 - Qual pH que eu preciso para precipitar sulfeto de cádmio?

Aluno A/5 - Ácido!

Aluno A/2 - É, meio ácido!

Pesquisador $\mathbf{P} / \mathbf{2}$ - O que vocês acham, não pode ser alcalino?

Aluno A/1 - Podee! Aí pode, não vai ter outro "pra" precipitar junto...

Aluno A/7 - Ah, é verdade!!!

Pesquisador P/2 - Não "tô" separando né, do grupo III, nem nada...

Aluno A/7 - No caso, o meio ácido é porque tinha o cobre junto...

Aluno A/5 - Base é só do grupo III, ácido é o grupo IV..

Mais uma vez, a discussão específica do experimento foi importante. Em roteiros prontos de aula didática experimental, os alunos normalmente separam grupo IV e depois o grupo III. Mudam o pH porque o roteiro indica esta ação e não refletem sobre a necessidade da mudança $\mathrm{pH}$. No caso do trecho específico da marcha analítica a ser analisada (amostra dos metais cádmio e chumbo), não havia nenhum representante do grupo III, fato que inviabilizava a mudança de $\mathrm{pH}$.

A visão geral da rota evidenciou a objetivação do problema. Era nossa intenção não limitar esta movimentação a um caso isolado. O "princípio do caráter objetal" pode nos auxiliar na discussão acerca da importância desta rota, agora materializada na lousa. Este faz referência a atividades que são desenvolvidas com objetos de assimilação para revelar o conceito em estudo e representar seu conteúdo por meio de objetos (NUNEZ, 2009). Para este autor, o caráter objetal,

(...) permite que os alunos descubram o conteúdo geral de um determinado conceito como fundamento da posterior identificação de suas manifestações particulares. O geral é a conexão geneticamente inicial que permite explicar o desenvolvimento do sistema de conhecimentos (p. 139).

Na figura 9 abaixo, há a rota de separação extraída do relatório de um dos grupos participantes, como exemplo desta materialização. 


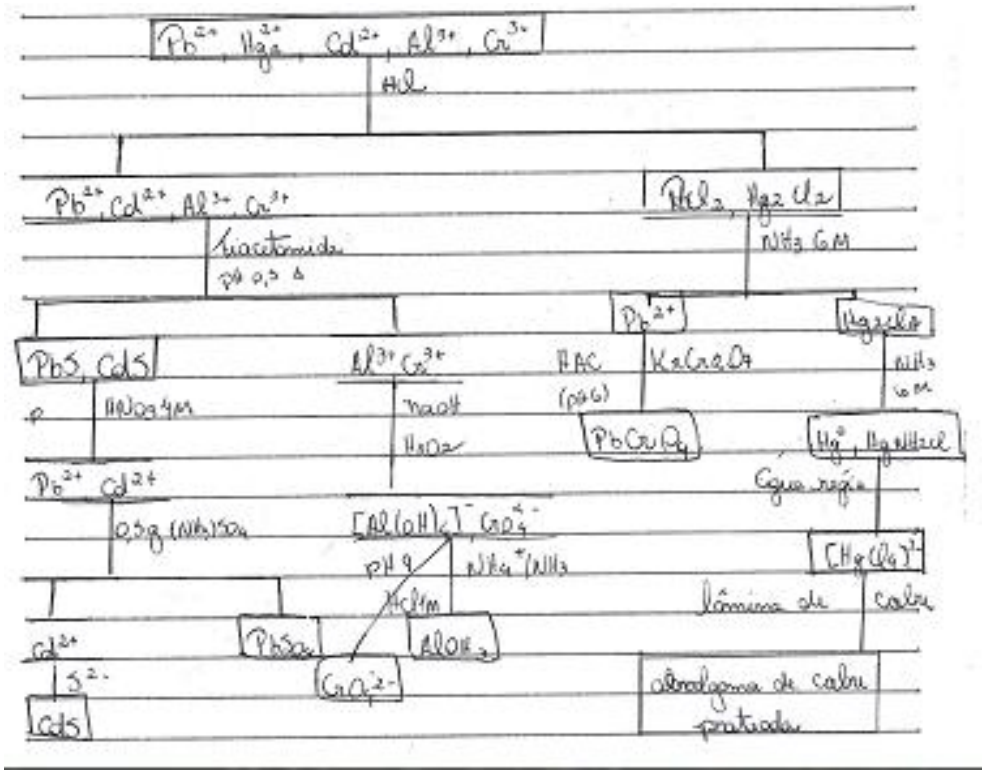

Figura 9: Rota construída coletivamente

Para se obter uma marcha analítica como esta, os alunos precisaram reunir nexos, relacionar conceitos de reagente de grupo, solubilidade e controle das condições de reação. Ao se reunir os nexos e relacionar o objeto de estudo com outros o conceito torna-se passível de internalização (VIGOTSKI, 1996, p. 81).

\section{$3^{\circ}$ Encontro: Atividade experimental - separação e identificação dos metais de uma amostra líquida fictícia de batons.}

De acordo com a rota teórica obtidas por eles (Figura 9, coluna da direita), chumbo e mercúrio (representantes do grupo analítico V) foram separados na forma sais de cloreto $\left(\mathrm{PbCl}_{2}\right.$ e $\left.\mathrm{Hg}_{2} \mathrm{Cl}_{2}\right)$ e após solubilização em água quente, o chumbo foi reprecipitado na forma de cromato $\left(\mathrm{PbCrO}_{4}\right)$.

Para identificar o mercúrio, foi necessária a utilização da água régia (solução de ácido clorídrico e ácido nítrico 3:1 respectivamente). O mercúrio existente na amostra é o de "número de oxidação I" e se desproporciona também em mercúrio metálico (zero). Para ser identificado, este mercúrio necessita ser oxidado a mercúrio II (inicialmente) e depois reduzido, ao ser colocado em contato com o cobre metálico, de acordo com a equação 6 a seguir (formação da amálgama de cobre):

Equação 6: $\mathrm{Hg}_{(\mathrm{aq})}{ }^{2+}+\mathrm{Cu}_{(\mathrm{s})} \rightarrow \mathrm{Cu}_{(\mathrm{aq})}{ }^{2+}+\mathrm{Hg}_{(\mathrm{s})}$ 
Nesta, o mercúrio é reduzido (conferindo um aspecto prateado no metal Figura 10 abaixo), ao passo que o cobre metálico é oxidado, conferindo uma coloração azulada na solução.

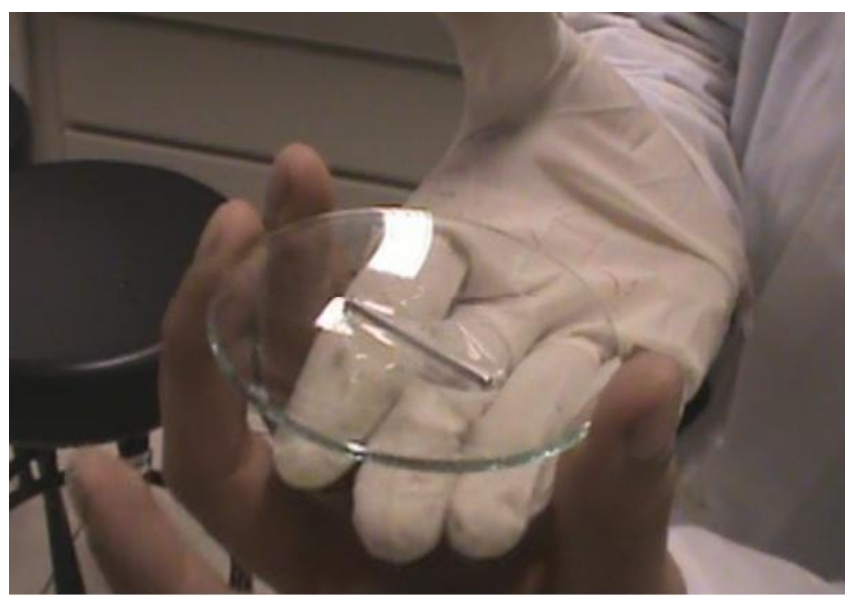

Figura 10: Formação da amálgama de cobre

Os alunos puderam visualizar a amálgama de cobre formada após adição do metal de cobre a solução que continha o mercúrio a ser identificado. De forma geral, todos os alunos desenvolveram esta etapa de separação do grupo V com êxito.

No que diz respeito à separação dos grupos IV e III, algumas dificuldades foram detectadas. $\mathrm{O}$ Chumbo que é um metal do grupo $\mathrm{V}$ possui relativa solubilidade em água, fato que proporcionou sua presença no sobrenadante (solução resultante após precipitação dos metais do grupo V) que deveria conter à priori apenas os metais dos grupos IV e III. Este problema foi discutido no encontro teórico, pelos próprios alunos envolvidos e algumas lacunas não foram sanadas. Seria necessário que os alunos “entrassem em atividade” para que a internalização deste conceito fosse possível. Acreditamos que alguns alunos este momento se deu durante a prática experimental.

Desta forma, o chumbo e cádmio foram precipitados juntamente com adição de tioacetamida $\left(\mathrm{CH}_{3} \mathrm{CSNH}_{2}\right.$, fonte de sulfeto) em meio ácido. Após a solubilização destes precipitados com ácido nítrico, o chumbo deveria ser reprecipitado na forma de sulfato (composto branco) e cádmio seria reprecipitado na forma de sulfeto (composto amarelado). Alguns alunos não conseguiram atingir este patamar do experimento, uma vez que se esqueceram de eliminar a tioacetamida. Esta ocorrência permitiu que o sulfeto ficasse disponível em solução para reprecipitar o chumbo ( $\mathrm{PbS}$, composto 
escuro). Este composto escuro precipitado inviabilizou a detecção do sulfeto de cádmio, que forma um precipitado amarelo.

Esta possibilidade de erro foi discutida e alguns grupos possivelmente internalizaram este conceito somente no dia do experimento. A fala de um aluno pôde ser registrada no laboratório e evidencia este movimento de aprendizagem:

Aluno A/5 Sempre ouvi falar que tinha que eliminar, eliminar excesso, aquecer, outras vezes levar a secura mais não sabia porque...se eu tivesse um procedimento aqui e tivesse lendo, eu ia eliminar sem saber porque...agora fazendo, sem roteiro, eи me questionei o por que...

Nesta fala do aluno, fica evidente que em outros momentos acadêmicos de sua prática experimental, no qual foi necessário levar a solução em análise à secura, o mesmo seguira a orientação do roteiro sem maiores reflexões acerca do problema.

Segundo Leontiev (1979),

O reflexo consciente do mundo não surge no sujeito como resultado da projeção direta sobre seu cérebro de representações e conceitos elaborados pelas gerações antecessoras. Sua consciência é também o produto de sua atividade no mundo dos objetos (p. 23).

Assim, interpretamos que o referido aluno $\mathrm{A} / 5$, no dia do encontro teórico não compartilhou das representações elaboradas pelos demais acerca do procedimento de se "levar a secura" a amostra em análise (se necessário, reveja a fala do aluno na página 72). Todavia, ao desenvolver ações tradicionais de laboratório e operar o experimento (uma atividade objetal), o aluno reestruturou seus conhecimentos para obter conhecimento novo.

É sabido que estes tópicos foram discutidos e esgotados em todas as aulas da QAQ e não somente naquelas destinadas a AOE. A "solução problema” deve ser levada a secura para minimizar excessos de reagentes, para mudança de $\mathrm{pH}$ do meio, ou quando o reagente tioacetamida é utilizado para precipitação e posteriormente se transforma em um interferente. Sua eliminação se fazia necessária para não inferir em outros testes de identificação. Neste interim, constatamos que para o aprendizado evoluir de um patamar a outro, foi necessário a participação efetiva do educando, 
recriando e vivenciando uma situação desencadeadora de aprendizagem que foi planejadamente subsidiada por um conceito historicamente acumulado.

Foi interessante observar que em todas as bancadas do laboratório didático experimental, o único material teórico disponível foi a folha com a rota (marcha analítica) desenvolvida nos dois encontros teóricos. Como os alunos não possuíam nenhum outro procedimento, a quantidade (volume) de reagentes a ser utilizado precisou ser ponderada no formato "tentativa e erro". Os alunos anotaram em seu procedimento a quantidade de reagentes a ser utilizada, que foi mensurada durante os encontros teóricos e experimentalmente (figura 11).

Abaixo apresentamos um trecho da discussão acerca dos volumes de reagentes a serem utilizados no experimento:

Aluno A/3 - Então sobre o volume que vai ser utilizado, esse vai ser meu desafio...

Pesquisador P/2 - Três, quatro, cinco, 10 gotas, vai depender do bom senso... (...)

Aluno A/5 - Pesquisador P/2 e sobre a concentração?

Pesquisador P/2 - Que concentração? Alguém já disse que era 6 mol por litro.

Aluno A/5 - Não, não, não "tô" falando disso, quanto que a gente vai por de cada reagente..tudo mais..

Aluno A/10 - Quantas gotas!!!

Pesquisador P/2 - Cada um (fazendo referência a cada dupla de laboratório), vai pegar 2 mL da amostra, tá?

Aluno A/5 - Mas aí, quanto que a gente tem que por de tioacetamida, e tudo mais.

Pesquisador P/2 - Veja bem, são $2 \mathrm{~mL}$ (de solução com os metais) e não difere muito das amostras que vocês tem trabalhado até agora em solução... Não amostra sólida que é diferente, mas as amostras em solução não diferem muito...ligeiramente acima do que...(Nos experimentos tradicionais, os alunos estavam acostumados a utilizar de três a cinco gotas dos reagentes). Neste momento o pesquisador foi à lousa novamente e apontou o início da marcha analítica:

Pesquisador P/2 - Então aqui, quanto vocês colocariam de ácido clorídrico 6 mol por litro, aqui..

Aluno A/5 - Umas cinco gotas? 
Aluno A/7 - Cinco!

Aluno A/11 - Eu colocaria umas 15.

Pesquisador P/2 - Não precisa exagerar...

A disciplina de QAQ envolve análises qualitativas e assim sendo, a precisão em relação à quantidade de reagentes não é considerada um fator limitante na consecução dos experimentos. Todavia, é necessário o bom senso e uma análise crítica do processo, que não é "engessado". Depois de uma rápida discussão, fecharam o uso de reagentes em 10 gotas (em média).

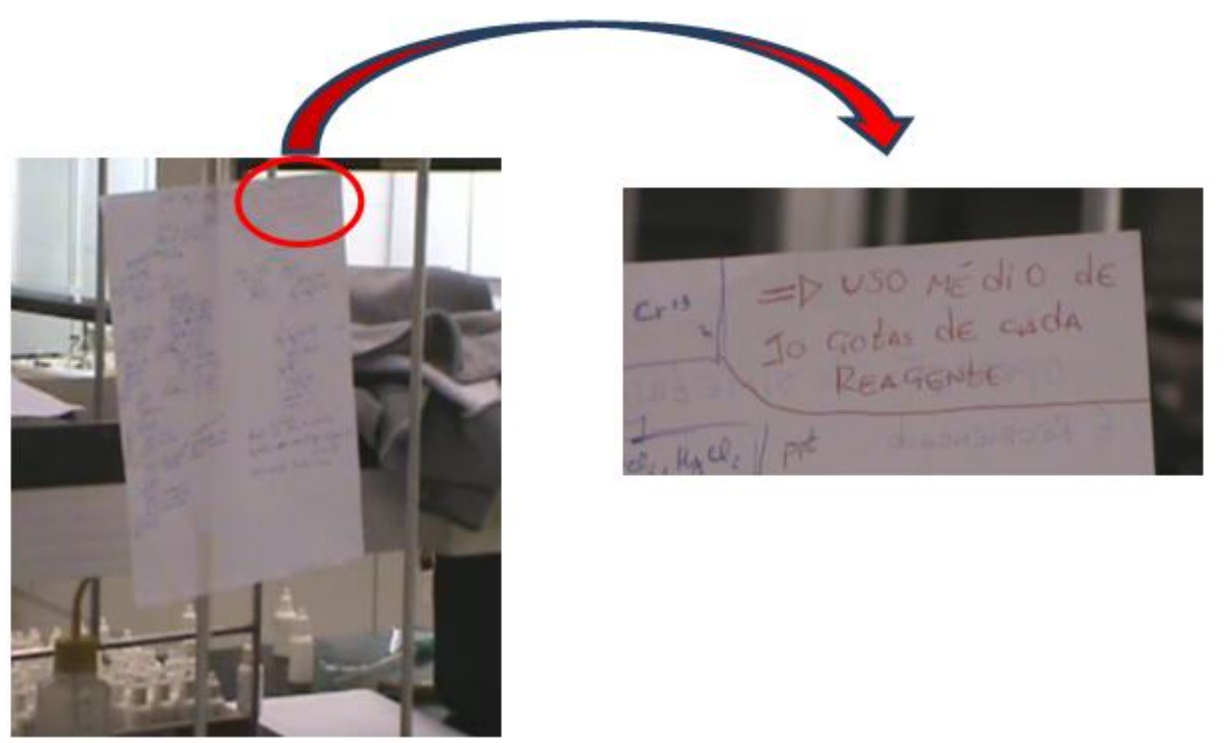

Figura 11: Rota construída coletivamente anexada nas bancadas - destaque para volume médio utilizado

Vale ressaltar que no momento em que a atividade foi desenvolvida, os alunos já haviam participado das aulas teóricas e práticas referentes aos grupos I, II e III (Quadro 1). Com relação aos grupos IV e V, nada foi apresentado até o término dos três encontros estipulados.

Apenas após o último encontro (experimental), os alunos receberam um material contendo informações experimentais e reações químicas referentes aos metais pesados abordados. Este material foi entregue para auxiliar os alunos durante o desenvolvimento do relatório. Além do relatório, uma questão teórico-experimental foi inserida na avaliação escrita dos discentes, completando assim a forma de avaliação prevista para esta AOE. 
Foi interessante observar a reação dos alunos ao receber o roteiro "pronto" no final do experimento. Segundo eles, neste momento o mesmo não seria mais necessário, uma vez que todo o trabalho e proposta já haviam sido desenvolvidos.

\section{CONCLUSÕES}

Ao acompanhar o processo de desenvolvimento da AOE reunimos elementos acerca da potencialidade desta metodologia na disciplina de QAQ, que residiu no fato de:

a) ter proporcionado que os alunos buscassem informações e desejassem resolver um problema, sendo portanto ativos no processo de aprendizagem. Aprender os conhecimentos de QAQ se tornou uma necessidade para analisar uma amostra de cosmético;

b) possibilitou que os conceitos estudados em QAQ fossem percebidos num contexto de história da humanidade, ou seja, os estudantes puderam questionar: por que separar metais? Quando na história da humanidade essa necessidade se fez presente? Por onde as pessoas naquela época começavam a análise? Atualmente, em que e para que estes conhecimentos são importantes?

c) reuniu conhecimentos que ultrapassam a formação química, para considerar a formação do ser humano, a medida que reúne aspectos éticos, históricos e sociais relacionados aos conteúdos da disciplina. Possibilitou a reflexão do profissional da química que atua em indústrias de cosméticos e usa os metais mesmo conhecendo seus efeitos no organismo humano e no meio ambiente. As esferas de responsabilidade em termos de contaminação ambiental também foram discutidas.

d) A metodologia criou um ambiente para a mediação do professor que foi estimulada e fundamental no processo.

e) auxiliou o aluno a se tornar consciente das ações que geralmente realiza na aula de laboratório, mas sem muito questionamento em outras metodologias tradicionais. A medida que se torna consciente é capaz de prever o produto 
final da ação e a partir daí, imaginar e aplicar o conhecimento em situações diferentes que sejam apresentadas, ou seja, favorece o pensamento teórico.

f) Criou condições para que o estudante estabelecesse relações entre os conceitos, formando um sistema com estes. Por exemplo, na definição de metal pesado, os alunos relacionaram diversos conceitos: densidade; massa atômica; ação do metal no organismo humano; impacto do conhecimento científico na sociedade; toxicidade e concentração, entre outros.

Além disso, a forma de organização proporcionou que o aluno tomasse consciência de sua própria atividade mental, à medida que tinha que argumentar as ações e decisões que tomariam na resolução do problema e identificação dos metais.

Foi possível notar o potencial da AOE para o movimento de um patamar de conhecimento para outro, utilizando-se situações desencadeadoras de aprendizagem que permitiram uma interação sócio histórica com o conceito relativo a metais pesados.

Concluímos que a AOE é um recurso metodológico em potencial para a disciplina de QAQ, uma vez que proporcionou colocar o conhecimento em movimento, favoreceu diálogos e socializações, propiciou a evocação das representações e estabelecimentos de nexos. A atividade contribuiu para a formação sistemática de aluno, e consequentemente, do professor.

Após elaborarem uma proposta coletiva de rota de separação, os alunos conseguiram separar e identificar com sucesso os metais envolvidos. Cada participante elaborou um relatório final onde os resultados foram apresentados e discutidos. Esta AOE foi inserida na matriz curricular na disciplina e contribuiu para a avaliação dos alunos, que receberam uma nota na forma de "Prática como Componente Curricular", item exigido no projeto político pedagógico do curso de Licenciatura em Química. Detectamos que o tempo total da atividade foi compatível com o tempo atual disponível para a disciplina que é oferecida no período noturno.

Toda a atividade foi pautada na significação, que foi ora evidenciada pela fala, ora pelas anotações dos alunos (dados conceituais e proposta de rotas experimentais) além das soluções para o problema proposto. Estes fatos evidenciaram a obtenção de conhecimento novo e a possibilidade de mudança psicológica.

Acreditamos que a grande contribuição deste trabalho foi utilizar uma metodologia na disciplina da QAQ pautada em referenciais da teoria histórico-cultural, explícitos desde o início. Apesar dos estudos na área de Educação, sabemos da 
dificuldade para que estes adentrem a sala de aula. A situação é ainda mais crítica se consideramos o ensino superior. Este trabalho abre perspectiva para que outras AOE sejam planejadas e utilizadas na referida disciplina, bem como, em outras disciplinas, principalmente de caráter experimental. 


\section{REFERÊNCIAS}

ABREU, D. G. de. Tratamento de resíduos químicos como recurso para a promoção da educação ambiental no ensino superior. 2003. 101p. Tese (Doutorado em Química). Departamento de Química da Faculdade de Filosofia, Ciências e Letras de ribeirão Preto, Universidade de São Paulo, São Paulo - SP.

ABREU, D. G. de; COSTA, C. R., ASSIS, M. D., IAMAMOTO, Y. Uma proposta para o ensino da química analítica qualitativa. Química Nova, v.29, p. 1381- 1386, 2006.

Alvim, T. R.; ANDRADE, J. C. de. A importância da Química Analítica Qualitativa nos cursos de Química nas instituições de ensino superior brasileiras. Química Nova, v.29, n.1, p.168-172, 2006.

ANASTASIOU, L. G. C., Alves, L. P. Ensinar, aprender, apreender e processos de ensinagem In Processos de ensinagem na universidade: pressupostos para as estratégias de trabalho em aula, p. 11-40. Joinville: UNIVILLE, 2009.

, . Metodologia de ensino na universidade brasileira: elementos de uma trajetória In Temas e Textos da Educação Superior, pp.1-10, Campinas: Papirus, 2001

ATKINS e JONES, Princípios de Química: questionando a vida moderna e o meio ambiente, $5^{\mathrm{a}}$ ed, 2012.

BACCAN, N., et al. Introdução à Semimicroanálise Qualitativa. $7^{\text {aed. }}$ Campinas: UNICAMP, 1997.

BAIRD, C.; Química Ambiental, W.H. 2ª ed. Bookman, Porto Alegre, 2004

BARRA, C. M. et al. Especiação de arsênio - uma revisão. Química Nova, vol. 23, n. 1, p. 58-70, 2000.

BRANDÃO, C. R., CAMPOS, M. M., DEMO, P. Seminário sobre pesquisa participativa. Texto básico. Brasília, INEP, 1984.

BRANDÃO, C. R., BORGES, M. C. A pesquisa participante: um momento de educação popular. Revista Ed. Popular, Uberlandia, vol. 6, p. 51-62, 2007.

CHAE, H, K., MOON, K. A. What is the Meaning of Heavy Metals ?: A Case Study In Korean Textbooks. Proceedingofthe $2^{\text {nd }}$ NICE Symposium, p. 1-7, 2007.

DAVIDOV, V. V. Tipos de generalización em la enseñanza. La Habana: Editorial Pueblo y Educación, 1983. 
DUARTE, N. A formação do indivíduo e a objetivação do gênero humano (tese de doutorado). Universidade Estadual de Campinas. Faculdade de Educação, p.1-54, 1992.

Formação do indivíduo. Consciência e alienação: o ser humano na psicologia de A.N. Leontiev. In: Cad. Cedes, Campinas, vol. 24, n. 62, p. 44-63, Abril, 2004.

ESPIMPOLO, D. M. Estudo da construção de conhecimento na disciplina de Química Analítica Qualitativa e a inserção de íons de Terras Raras no processo de separação analítica de cátions. Ribeirão Preto, 2013. 154p. Dissertação (Mestrado em Química). Departamento de Química da Faculdade de Filosofia, Ciências e Letras de ribeirão Preto, Universidade de São Paulo, São Paulo - SP. 2013.

ESMPIMPOLO, D. M., IAMAMOTO, Y., ABREU, D. G. de. Atividade orientadora de ensino e a apreensão de conhecimentos em química. Revista Brasileira de Pesquisa em Educação em Ciência, vol. 12, n³, p. 105-129, 2012.

EZPELETA, J., ROCKWELL, E. (1986). Pesquisa participante. São Paulo: Cortez, 1986.

FRANCO, M. A. S., GHEDIN, E., PIMENTA, S. G.(orgs). Docência e pesquisa em formação de professores: caminhos que se cruzam nas cartas pedagógicas. In Pesquisa em educação - alternativas investigativas com objetos complexos p.137-148. São Paulo: Loyola, 2006.

FRESENIUS, K. R., Traité d'Analyse Chimique Qualitative, 6éme ed., Ed. Françoise: Paris, 1879.

GALPERIN, P. Ya. Sobre La formación de lãs imágenes sensoriales y de conceptos. In ROJAS, L. Q. (Comp). La formación de lãs funciones psicológica durante el desarrollo del niño. Tlaxcala: Editora Universidad Autónoma de Tlaxcala, 2001d, p. 27-40.

GONZALEZ, P. O. El enfoque histórico-cultural como fundamento de uma concepción pedagógica. Tendencias Pedagógicas Contemporáneas. La Habana: MÊS, p. 92-112, 1991.

HAWKES, S. J. What is a heavy metal? Journal of Chemical Education, vol. 74, n. 11, p. 1374, 1997.

KOSIK, K. Dialética do concreto; Rio de Janeiro: Paz e Terra, 1926.

LEONTIEV, A.N. O desenvolvimento do psiquismo. Lisboa. Livros Horizontes LDA, 1978.

Educación, 1979.

Qué és La personalidad? La Habana: Libros para La 
. El problema de La actividad em la psicologia. In COLECTIVO DE AUTORES. Temas sobre la actividad y la comunicación. Psicología Social. La Habana: Editorial de Ciencias Sociales, 1989a, p. 259-298.

Sobre La formación de lãs capacidades. In COLECTIVO DE AUTORES. Temas sobre la actividad y la comunicación. Psicología Social. La Habana: Editorial de Ciencias Sociales, 1989b, p. 44-54.

Ciência Del Hombre, 1983.

Actividad, conciencia, personalidad. Buenos Aires,:

LIMA, V. F., MERÇON, F. Os metais pesados no Ensino de Química, Revista Química Nova na Escola, vol. 33, n4, p. 199 - 205, 2011.

MARCO, F. F. Atividade orientadora de ensino de matemática na formação inicial de professores. Revista Educação Matemática Pesquisa, vol.15, n², p. 317-336, 2013.

MAZZOTTI, A. J. A. Relevância e aplicabilidade da pesquisa em educação. Cadernos de Pesquisa, vol. 113, n¹, p.39-50, 2001.

MARX, K.; ENGELS, F. A ideologia alemã (Feuerbach). 9. ed. São Paulo: HUCITEC, 1993.

MOURA, M. O. A construção do signo numérico em situação de ensino. Tese (Doutorado em Educação) - Universidade de São Paulo, São Paulo, 1992.

Líber Livro, 2010.

$A$ atividade pedagógica na teoria Histórico-Cultural. Brasília:

MOURA, M. O., et al. Atividade orientadora de ensino: unidade entre ensino e aprendizagem. Revista Diálogo Educacional, vol. 10, n²9, p. 205-229, 2010.

NUNEZ, I. B. Galperin, Leontiev e Vygotsky. Formação de conceitos e princípios didáticos. Brasília: Líber Livro, 2009

RHEINBOLDT, H. e HAUPTMANN, H. Guia de Química Analítica Qualitativa - destinado ao uso do Curso prático do Instituto de Química da Universidade de São Paulo, 1975.

RHEINBOLDT, H. O Ensino Superior de Química. Ciência e Cultura, vol.3, n2, 1951.

RICHTER,, L. M. Resenha: Clássico Marxista: "dialética do concreto". Revista Educação e Políticas em Debate, vol.1, n¹, p.236-248, 2012. 
SENISE, P. Origem do Instituto de Química da USP - reminiscências e comentários. São Paulo: Instituto de Química da USP, 188 p., 2006.

SEVERINO, A. J. Problemas e dificuldades na condução da pesquisa no curso de pós-graduação. In: FAZENDA, Ivani (Org.). Novos enfoques da pesquisa educacional. 4. ed. São Paulo: Cortez, p. 27-34, 2001.

VYGOSTKY, L. S. A formação social da mente. $6^{\text {a }}$ ed. São Paulo: Martins Fontes, 2002.

Imaginación y creación em la edad infantil. La Habana:

Editorial Pueblo y Educación, 1985

Pensamento e Linguagem. Trad. Jeferson Luiz Camargo. São Paulo: Martins Fontes, 1989.

VOGEL,, A. I.; Química Analítica Qualitativa, 5ª ed., Mestre Jou: São Paulo, 1981.

VEER,, R.V.D., \& VALSINER, J. A teoria histórico cultural InVygotsky Uma síntese, p.203-281, São Paulo: Edições Loyola, 1996.

http://g1.globo.com/bemestar/noticia/2013/05/estudo-dos-eua-alerta-paraindices-de-metais-em-batons-e-brilhos-labiais.html Acesso em 10 de maio de 2013.

http://ehp.niehs.nih.gov/wp-content/uploads/121/6/ehp.121-a196.pdf Acesso em 08 de dezembro de 2013.

http://www.ffclrp.usp.br/graduacoes/quimica/licenciaturaemquimica.php Acesso em 23 de março de 2014.

http://g1.globo.com/bemestar/noticia/2014/01/anvisa-determina-apreensao-detintas-para-tatuagem-da-marca-supreme.html Acesso em 25 de março de 2014.

http://www.cetem.gov.br/mercurio/semiquanti/por/caso_minamata.htm Acesso em 25 de março de 2014.

http://portal.mec.gov.br/seed/arquivos/pdf/tvescola/leis/lein9394.pdf Acesso em 25 de março de 2014.

http://www.ufjf.br/farmacologia/files/2013/05/FI-AULA-4-

FARMACODINAMICA.pdf Acesso em 20 de abril de 2014. 
8. ANEXOS 


\section{ANEXO I: AOE - Metais pesados}

Disponivel em:

$<$ http/lig1. globo.com/bemestarinoticia/2013/05/est udo-dos-eua-alerta-para-indices-de-metais-embatons-e-brilhos-labiais $\mathrm{html}$ ?. Acesso em $10 \mathrm{de}$ maio de 2013.

\section{Estudo dos EUA alerta para índices de} metais em batons e brilhos labiais

Pesquisa encontrou chumbo, cádmio e cromo em cosméticos analisados. Alguns componentes químicos estão relacionados a doenças como câncer.

Pesquisadores da Universidade da Califórnia, nos Estados Unidos, analisaram 32 tipos diferentes de batons e brilhos labiais e detectaram a presença de metais como chumbo, cádmio, cromo e alumínio em pequenas $e$ grandes quantidades nesses produtos. $O$ fato preocupa pois alguns desses componentes químicos constantemente são relacionados a doenças graves como $\circ$ câncer. O estudo, divulgado nesta quinta-feira (2) na revista "Environmental Health Perspectives", aponta a necessidade de maior regulamentação desses cosméticos no país, já que nos Estados Unidos não há uma lei especifica sobre metais em cosméticos.

Foram analisados 8 batons e 24 brilhos labiais de 7 diferentes empresas. Os preços dos produtos variavam de USS 5,59 a US\$ 24 e eram os mais usados por jovens, de acordo com estatistica obtida pelos investigadores.

Segundo o estudo, em dez amostras das 32 analisadas, foram encontrados níveis de cromo acima do tolerável, se considerada a média diária de ingestäo involuntária. Além disso, em 24 produtos havia presença de chumbo. Apesar do nível não ser considerado alarmante, sua presença preocupa devido à possível exposição a crianças.

Ingestão involuntária

Os cientistas analisaram ainda o impacto da ingestão involuntária da maquiagem. Uma pessoa comum ingere em média 24 miligramas por dia de batom ou gloss (que vai para o estômago com a saliva). Em casos de uso excessivo, a ingestão pode chegar a 87 miligramas.
De acordo com os pesquisadores, a ingestão de maquiagem com metais oferece riscos à saúde. A exposição excessiva ao cromo, por exemplo, preocupa porque a substância é cancerígena e normalmente está relacionada a tumores no estômago.

A presença de manganês nesses produtos pode também oferecer risco, já que o metal pode causar danos ao sistema nervoso.

Os cientistas disseram que não há nenhuma razão para lançar tais produtos no lixo após os resultados. No entanto, a quantidade de metais encontrada sinaliza a necessidade de aumentar a fiscalização desses produtos por órgãos regulares de saúde.

A pesquisa aponta ainda que não existem normas americanas para metais em cosméticos. No entanto, ressaltam que a União Europeia considera o cádmio, cromo e chumbo ingredientes inaceitáveis, em quaisquer níveis, em produtos cosméticos.

\section{Atividade Orientadora:}

Imagine que você é o químico contratado pela empresa que investiga o fato descrito na noticia. Uma empresa televisiva the convidou para dar uma entrevista explicando para população do ponto de vista científico qual é o problema com os metais pesados. $O$ jomalista adiantou que a população quer saber o que é um metal pesado, o que sua ingestão pode causar para saúde humana, quais concentrações são toleráveis e etc. Desta forma, você deverá elaborar um texto breve com esta finalidade.

Um químico, após tratamento adequado e isolamento dos íns metálicos de vários lotes de amostras dos cosméticos sob suspeita (batons), deixou no laboratório um béquer com o residuo obtido. Suponha que tal solução gerada na análise possa conter altas concentrações dos metais citados na notícia. Para decidir que destino dar a este resíduo, caberá a você propor uma rota para separar e identificar os possiveis metais. No $2^{\circ}$ encontro será realizada a análise da solução fictícia de batons e emissão do parecer sobre a composição e destinaçâo final dos metais presentes. 


\section{ANEXO II: Classificação Metais Pesados - Duffus (2002)}

1. Definitions in terms of density (specific gravity)

- Metals fall naturally into two groups - the light metals with densities below 4 and the heavy metals with densities above 7 [6].

- Metal having a density greater than 4 [10]

- Metal of high density, especially a metal having a density of 5.0 or over [25]

- Metal with a density greater than 5 [26]

- Metal with a density greater than $6 \mathrm{~g} / \mathrm{cm} 3[27]$

- Metal of density greater than 4 [11]

- Metal with a density of 5.0 or greater [28]

- Metal whose density is approximately 5.0 or higher [12]

- Metal with a density greater than 5 [13]

- (In metallurgy) any metal or alloy of high density, especially one that has a density greater than $5 \mathrm{~g} / \mathrm{cm}^{3}[14]$

- Metal with a density higher than $4.5 \mathrm{~g} / \mathrm{cm}^{3}[15]$

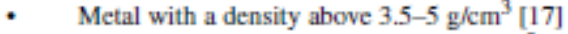

- Element with a density exceeding $6 \mathrm{~g}^{-\mathrm{cm}^{3}}$ [16]

2. Definitions in terms of atomic weight (relative atomic mass)

- Metal with a high atomic weight [29]

- Metal of atomic weight greater than sodium [18]

- Metal of atomic weight greater than sodium (23) that forms soaps on reaction with fatty acids [19]

- Metallic element with high atomic weight; (e.g., mercury, chromium, cadmium, arsenic, and lead); can damage living things at low concentrations and tends to accumulate in the food chain [30]

- Metallic element with an atomic weight greater than 40 (JHD note-starting with scandium Atomic Number 21). Excluded are alkaline earth metals, alkali metals, lanthanides and actinides [20]

- Metal with a high atomic mass [31]

- "Heavy metals" is a collective term for metals of high atomic mass, particularly those transition metals that are toxic and cannot be processed by living organisms, such as lead, mercury, and cadmium [32]

- Metal such as mercury, lead, tin, and cadmium that has a relatively high atomic weight [33].

- Rather vague term for any metal (in whatever chemical form) with a fairly high relative atomic mass, especially those that are significantly toxic (e.g., lead, cadmium, mercury). They persist in the environment and can accumulate in plant and animal tissues. Mining and industrial wastes and sewage sludge are potential sources of heavy metal pollution [34].

- A metal such as cadmium, mercury, and lead that has a relatively high relative atomic mass. The term does not have a precise chemical meaning [35]

- Metal with a high relative atomic mass. The term is usually applied to common transition metals such as copper, lead or zinc [36]

3. Definitions in terms of atomic number

- In electron microscopy, metal of high atomic number used to introduce electron density into a biological specimen by staining, negative staining, or shadowing [37]

- In plant nutrition, a metal of moderate to high atomic number e.g., $\mathrm{Cu}, \mathrm{Zn}, \mathrm{Ni}, \mathrm{Pb}$, present in soils due to an outcrop or mine spoil, preventing growth except for a few tolerant species and ecotypes [37].

- The rectangular block of elements in the periodic table flanked by titanium, hafnium, arsenic, and bismuth at its corners but including also selenium and tellurium. The densities range from 4.5 to $22.5 \mathrm{~g} / \mathrm{cm}^{-3}$ [22]

- Any metal with an atomic number beyond calcium [38]

- Any element with an atomic number greater than 20 [39]

- Metal with an atomic number between 21 (scandium) and 92 (uranium) [21]

- Term now often used to mean any metal with atomic number $>20$, but there is no general concurrence [3] 


\section{CONTINUAÇÃO - ANEXO II: Classificações Metais Pesados - Duffus} (2002)

Table 2 (Continued)

4. Definitions based on other chemical properties

- "Heavy metals" is the name of a range of very dense alloys used for radiation screening or balancing purpose. Densities range from $14.5 \mathrm{~g} / \mathrm{cm}^{-3}$ for $76 \% \mathrm{~W}, 20 \% \mathrm{Cu}, 4 \% \mathrm{Ni}$ to $16.6 \mathrm{~g} / \mathrm{cm}^{-3}$ for $90 \% \mathrm{~W}, 7 \% \mathrm{Ni}$, $3 \% \mathrm{Cu}[40]$.

- Intermetallic compound of iron and tin $\left(\mathrm{FeSm}_{2}\right)$ formed in tinning pots which have become badly contaminated with iron. The compound tends to settle to the bottom of the pot as solid crystals and can be removed with a perforated ladle [41].

- Lead, zinc, and alkaline earth metals that react with fatty acids to form soaps. "Heavy metal soaps" are used in lubricating greases, paint dryers, and fungicides [42].

- Any of the metals that react readily with dithizone $\left(\mathrm{C}_{6} \mathrm{H}_{5} \mathrm{~N}\right)$, e.g., zinc, copper, lead, etc. [43]

- Metallic elements of relatively high molecular weight [44].

5. Definitions without a clear basis other than toxicity

- Element commonly used in industry and generically toxic to animals and to aerobic and anaerobic processes, but not every one is dense nor entirely metallic. Includes $\mathrm{As}, \mathrm{Cd}, \mathrm{Cr}, \mathrm{Cu}, \mathrm{Pb}, \mathrm{Hg}, \mathrm{Ni}, \mathrm{Se}, \mathrm{Zn}$ [45].

- Outdated generic term referring to lead, cadmium, mercury, and some other elements which generally are relatively toxic in nature; recently, the term toxic elements has been used. The term also sometimes refers to compounds containing these elements [23].

6. Nonchemical definitions used before $\mathbf{1 9 3 6}$

- Guns or shot of large size [7]

- Great ability [8] 


\section{ANEXO III: Solubilidade dos cloretos dos cátions do grupo V}

Solubilidade em água dos cloretos dos cátions do grupo $\mathrm{V}$

\begin{tabular}{|c|c|c|}
\hline Cloreto & Solubilidade em g/L a $25^{\circ} \mathrm{C}$ & Solubilidade em $\mathrm{mol} / \mathrm{L}$ \\
\hline $\mathrm{Hg}_{2} \mathrm{Cl}_{2}$ & 0,00038 & $8,1 \times 10^{-7}$ \\
\hline $\mathrm{AgCl}$ & 0,00179 & $1,25 \times 10^{-5}$ \\
\hline $\mathrm{PbCl}_{2}$ & 11,0 & 0,0395 \\
\hline
\end{tabular}


ANEXO IV: Constante produto de solubilidade (Kps) para os sulfetos dos grupos III e IV

\begin{tabular}{cc|cc}
\hline \multicolumn{2}{c|}{ Grupo III } & \multicolumn{2}{c}{ Grupo IV } \\
\hline & & $\mathrm{SnS}$ & $1,0 \times 10^{-25}$ \\
& & $\mathrm{SnS}_{2}$ & $<10^{-60}$ \\
$\mathrm{MnS}$ & $2,5 \times 10^{-13}$ & $\mathrm{Sb}_{2} \mathrm{~S}_{3}$ & $5,0 \times 10^{-51}$ \\
$\mathrm{NiS}$ & $3,3 \times 10^{-19}$ & $\mathrm{As}_{2} \mathrm{~S}_{3}$ & $2,1 \times 10^{-21}$ \\
$\mathrm{CoS}$ & $4,0 \times 10^{-21}$ & $\mathrm{Bi}_{2} \mathrm{~S}_{3}$ & $1,6 \times 10^{-72}$ \\
$\mathrm{ZnS}$ & $1,0 \times 10^{-21}$ & $\mathrm{CdS}$ & $8,2 \times 10^{-27}$ \\
& & $\mathrm{CuS}$ & $6,3 \times 10^{-36}$ \\
& & $\mathrm{HgS}$ & $1,6 \times 10^{-52}$ \\
\hline
\end{tabular}




\section{ANEXO V: Distribuição de carga horária - Licenciatura em Química}

Tabela 2. Distribuição da carga horária no curso de Licenciatura em Química oferecido no período noturno pelo DQ da FFCLRP-USP.

\begin{tabular}{|c|c|c|c|c|}
\hline Disciplina & PCC & ES & $\mathrm{CCNCC}$ & AACC \\
\hline Química Geral Experimental & 9 & & 111 & \\
\hline Iniciação à Química & 9 & & 111 & \\
\hline Nocões de Sequrança em Laboratórios de Química & & & 30 & \\
\hline Introdução ao Curso de Licenciatura em Química & 21 & & 9 & \\
\hline Cálculo Diferencial e Integral I & & & 60 & \\
\hline Cálculo Diferencial e Integral II & & & 60 & \\
\hline Física I para a Licenciatura & & & 90 & \\
\hline Geometria Analítica & & & 30 & \\
\hline Química Analítica Qualitativa & 5 & & 85 & \\
\hline Complementos de Matemática para a Química & & & 30 & \\
\hline Física II para a Licenciatura & & & 60 & \\
\hline Mineralogia & 3 & & 27 & \\
\hline Química Analítica Quantitativa & 4 & & 86 & \\
\hline Fisico-Química I: Físico Química de Equilibrio & 5 & & 55 & \\
\hline Física III para Licenciatura & & & 60 & \\
\hline Química Inorgânica I & 5 & & 55 & \\
\hline Físico-Química II: Físico-Química Dinâmica & 3 & & 57 & \\
\hline Introducão à Química Quântica & 3 & & 57 & \\
\hline Química Orgânica I & 4 & & 56 & \\
\hline Fisico-Química Experimental & 5 & & 85 & \\
\hline Química Orgânica II & 4 & & 56 & \\
\hline Química Inorgânica II & 3 & & 57 & \\
\hline Bioquímica Teórica I & 2 & & 28 & \\
\hline Química Orgânica III & 4 & & 56 & \\
\hline Química Inorgânica Experimental & 4 & & 56 & \\
\hline Métodos Instrumentais & 4 & & 86 & \\
\hline Bioquímica Teórica II & 2 & & 28 & \\
\hline Química Orgânica Experimental & 5 & & 85 & \\
\hline Química do Meio Ambiente & 6 & & 24 & \\
\hline Bioquímica Experimental & 5 & & 55 & \\
\hline Atividades Científico Culturais & 40 & & & 50 \\
\hline História da Química & 30 & & & 30 \\
\hline Introducâo aos Estudos da Educação em Ciências & 30 & & & 30 \\
\hline Introducão aos Estudos sobre Educação & & & 30 & \\
\hline Política e Gestăo Educacional no Brasil & & 30 & 60 & \\
\hline Psicologia Educacional & & 60 & 60 & \\
\hline Didática Geral I & & 60 & 60 & \\
\hline Metodologia do Ensino em Química I & & 30 & 30 & \\
\hline Metodologia do Ensino em Química II & & 30 & 30 & \\
\hline Didática das Ciências & & 30 & 30 & \\
\hline Química para o Ensino Médio I & 20 & 40 & & \\
\hline Química para o Ensino Médio II & 30 & 60 & & \\
\hline $\begin{array}{c}\text { Metodologia Científica da Pesquisa em Ensino de } \\
\text { Química e de Ciências }\end{array}$ & 15 & & 15 & 30 \\
\hline Atividades Integradas de Estágio & & 60 & 30 & \\
\hline
\end{tabular}




\section{CONTINUAÇÃO - ANEXO V: DISTRIBUIÇÃO DE CARGA HORÁRIA - LICENCIATURA EM QUÍMICA}

\begin{tabular}{|c|c|c|c|c|}
\hline Monografia em Ensino de Química e de Ciências I & 15 & & & 75 \\
\hline Monografia em Ensino de Química e de Ciências II & 15 & & & 75 \\
\hline $\begin{array}{c}\text { Monografia Supervisionada em Ensino de Química e } \\
\text { de Ciências }\end{array}$ & & & & 30 \\
\hline Supervisão Integrada de Estágio I & 30 & & & \\
\hline Supervisão Integrada de Estágio II & 30 & & & \\
\hline Supervisão Integrada de Estágio III & 30 & & & \\
\hline Introdução à Língua Brasileira de Sinais & & & 30 & \\
\hline Total: & 400 & 400 & $2120 \mathrm{~h}$ & $320 \mathrm{~h}$ \\
\hline
\end{tabular}

PCC: prática como componente curricular

ES: estágio supervisionado
CCNCC: conteúdos curriculares de natureza científico cultural

AACC: atividades acadêmico-científico-culturais 